DETERMINING THE SOURCE OF NITRATE IN GROUNDWATER BY NITROGEN ISOTOPE STUDIES

APPROVED BY SUPERVISORY COMMITTEE:

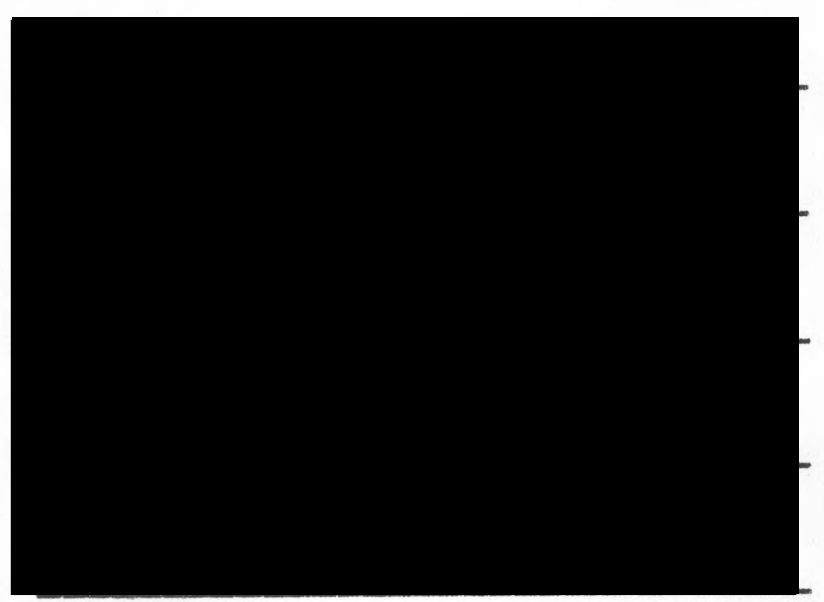




\title{
DETERMINING THE SOURCE OF NITRATE IN GROUNDWATER BY NITROGEN ISOTOPE STUDIES
}

\section{by}

CHARLES WIGHTMAN KREITLER, B.S., M.A.

\author{
DISSERTATION \\ Presented to the Faculty of the Graduate School of \\ The University of Texas at Austin \\ in Partial Fulfillment \\ of the Requirements \\ for the Degree of \\ DOCTOR OF PHILOSOPHY
}




\section{PREFACE}

This study was made possible by numerous contributions from many people. The study was started by Dr. David C. Jones of the Radian Corporation as part of the Environmental Protection Agency Project 16060 HNI. I am deeply grateful to the Radian Corporation, and to Dr. Jones, for financial and scientific support.

In the Fall of 1972, I transferred my laboratory work from the Radian Corporation to the Department of Geological Sciences, The University of Texas at Austin, where I completed the experimental aspects of this study under the guidance of Dr. L. J. Turk and Dr. Lynton S. Land. The untiring efforts of these professors have been greatly appreciated. During the last year of experimentation, I received the AMOCO Fellowship.

In Runnels County, Texas, where groundwater and soll samples were collected, the generosity of the landowners was overwhelming. I would like to especially thank Werner Lange and Paul Pieper for their interest in this study.

In Missouri, Dr. George Smith and Mr. Gerald Kerr, both of the Extension Service of the University of Missouri, helped collect water samples from Macon County, Missouri. Dr. Olin Braids and Mr. Pete Maniscalco of the U. S. Geological Survey, Water Resource Division, Mineola, New York, helped collect water samples in Queens and Nassau Counties, Long 
Island, New York. Mr. and Mrs. Steve Fisher of Brashear, Texas, rebuilt my truck engine when it blew up on the return trip from Long Island.

Dr. Harry Svec, Ames Laboratory, Iowa State University, provided a nitrogen standard gas. Teledyne Isotope Corporation analyzed three groundwater samples for the tritium concentrations.

I would like to thank Dr. L. J. Turk, Dr. Lynton S. Land, Dr. Keith Young, Dr. Peter T, Flawn, and Dr. Stanley N. Davis for their critical review of this dissertation.

Finally, I would like to especially thank my wife, Berf. She prepared samples, chased cattle for ammonia gas collection, and drafted, typed, and edited the preliminary draft of this dissertation.

This dissertation was submitted to the Committee in May 1974 . 


\section{DETERMINING THE SOURCE OF NITRATE IN GROUNDWATER}

\section{BY NITROGEN ISOTOPE STUDIES}

by

Charles W. Kreitler

\section{A $\quad$ B $\quad S$ T R A C T}

Nitrogen isotope ratios of ammonium and nitrate ions from soil and water samples can be analyzed reproducibly with an experimental error of approximately $\pm 10 / 00$.

Two isotopic ranges of soil nitrate are found in the soils of southern Runnels County, Texas. Nitrate from the decomposition of animal waste nitrogen has a $\delta N^{15}$ of $+100 / 00$ to $+22 \% 0$. The isotopic ratio is controlled by the volatilization of isotopically light ammonia gas during the decomposition of urea in urine. Nitrate derived from the mineralization of organic nitrogen in cultivated soils has a $\delta N^{15}$ of $+2 \% 00$ to $+8 \% 00$. In southern Runnels County the major source of nitrate in groundwater is natural soil nitrate. The isotopic composition of groundwater nitrate beneath cultivated fields corresponds with $\delta N^{15}$ of natural soil nitrate. Groundwaters beneath farmhouse-barnyard complexes have a higher average $\delta \mathrm{N}^{15}$, indicating the addition of animal waste nitrate. Eleven samples of groundwater from Macon County, Missouri, have $\delta N^{15}$ of $+10 \%$ to $+19 \%$ indicating that the waters are contaminated with nitrate from animal wastes. 
Nitrates in groundwaters from the Upper Glacial aquifer in Queens County, New York, appear to be from an animal waste source, whereas nitrates in groundwaters from the Magothy aquifer in Nassau County, New York, appear to be from either natural soil nitrogen or artificial fertilizer. 
TABLE OF CONTENTS

Page

Introduction .................. 1

Methods of analysis. . . . . . . . . . . 4

Sample preparation and isotopic analysis

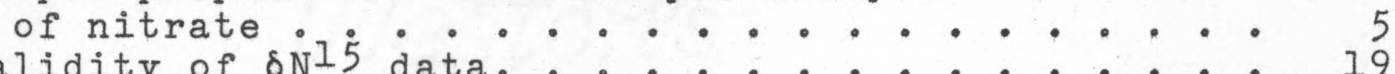

Colldity or o. . . . . . 19

Collection of water samples.: $:$ : : : : : 26

Collection of ammonia gas samples. . . . . . . 30

$\delta \mathrm{N}^{15}$ of soil nitrate, southern Runnels County,

Texas................. . . 32

Alternate methods of study ....... . 32

Results and discussion of $\delta N 15$ of nitrate

in different soil environments....... 34

Nitrates in soils from barnyards

and septic tank laterals........ . 36

Nitrates in soils from cultivated

fields and turnroads with no his-

tory of cattle.......... 36

Nitrates in soils from corn fields

with grazing cattle......... . 45

Nitrates in soils from prairies........ 48

Isotopic fractionation controlling $\delta \mathrm{N}^{15}$ of

nitrate in southern Runnels County, Texas. . . . . 51

Isotopic fractionation and its role in

natural systems............. 51

Nitrogen isotope fractionations related

to soils............... . . 54

Nitrogen fixation............. 54

Nitrification. . . . . . . . . . . . . 55

Denitrification. . . . . . ...... 56

Ion exchange.................. 57

Ammonia volatilization . . . . . . . . . 57

Nutrient assimilation. . . . . . . . . . 58

Fractionations within more complex

plants and animals......... 58

Mineralization ............ 61

Discussion of isotopic fractionations in

southern Runnels County, Texas ........ 62

Soils contaminated with animal wastes.... . 62

Soils from cultivated fields with no

animal wastes.......... 70 
$\underline{\text { Page }}$

Isotopic composition of nitrogen fertilizers . . . . 83 $\delta \mathrm{N}^{15}$ of groundwater $\mathrm{NO}_{3}$ versus $\delta \mathrm{N}^{15}$ of soil $\mathrm{NO}_{3} . . . .86$ Southern Runnels County, Texas.......... 89 Levels of nitrate contamination. . . . . . 89 Hydrogeology ............. . 89 Land-use practice. . . . . . . . . . . 90 $\delta N^{15}$ of nitrate in groundwater....... 91 Causes of high nitrates. . . . . . . . . . 99 Macon County, Missouri........... 106 Hydrogeology ................ 107 Land-use practice. . . . . . . . . . 107 $\delta N^{15}$ of nitrate in groundwater........ 108 Long Island, New York. .............. 112 Hydrogeology ............... . 113 Land-use practice. . . . . . . . . . 113 $\delta N^{15}$ of nitrate in groundwater....... 117

Conclusions................ 122

References.................. 141 Vita . . . . . . . . . . .... 151

\section{APPENDICES}

Appendix

$\underline{\text { Page }}$

1. Reagents used in $\delta N^{15}$ analysis ....... 126

2. Analyses of water samples from southern Runnels County, Texas........... 128

3. Analyses of soils from southern Runnels County, Texas............. 129

4. Soil associations of Runnels County, Texas............... 130

5. Analyses of groundwater samples, Macon County, Missouri . . . . . . . . . 132

6. Groundwater dates of waters in Runnels County, Texas, by tritium analysis ....... 


\section{TABLES}

Table

Page

1. Experimental fractionation of groundwater nitrate and soil nitrate by coarse-grained Devardas Alloy

2. Effectiveness of degassing sample of atmospheric nitrogen by freeze-thaw technique as analyzed by a mass spectrometer . . . . . . 15

3. $\delta N^{15}$ reproducibility of analyses of replicate $\mathrm{CaNO}_{3} \mathrm{H}_{2} \mathrm{O}$ and $\mathrm{NH}_{4} \mathrm{Cl}$ solutions . . . . . . . . 18

4. $\delta \mathrm{N}^{15}$ of atmospheric nitrogen and of Mathewson prepurified tank nitrogen. . . . . . . . . .

5. $\delta N^{15}$ reproducibility of analyses of replicate $\mathrm{KNO}_{3}$ and $\left(\mathrm{HN}_{4}\right)_{2} \mathrm{SO}_{4}$ solutions ........... 23

6. $\delta N^{15}$ reproducibility of analyses of replicate samples of groundwater nitrate . . . . . . . 29

7. Isotope equilibria constants . . . . . . . . 52

8. Accumulation of $\delta \mathrm{N}^{15}$ in proteins of rats... . . 60

9. Published data on the $\delta N^{15}$ of total nitrogen of soils and incubated soil nitrate. . . . . . 63

10. Nitrogen compounds in bovine urine . . . . . 64

11. Ammonia volatilization . . . . . . . . . 67

12. Dynamics of nitrate-N, in chernozems of the Borgoi, Buryat ASSR................

13. Dynamics of water-soluble ammonium-N, in chernozem soil, Borgoi, Buryat, ASSR . . . . . 76

14. $\delta \mathrm{N}^{15}$ of various forms of nitrogen in soils . . . 79

15. $\delta \mathrm{N}^{15}$ differences between total nitrogen of cultivated soils and virgin soils... . . . . . 81

16. $\delta N^{15}$ of nitrogen in artificial fertilizers . . . 84

17. Nitrate in aquifers of central Texas . . . . . . 87 
18. Average nitrogen content in various soils of the United States . . . . . . . . . 102

19. Major hydrogeologic units in Kings County, Long Island, New York. . . . . . . . . 114

20. $\delta \mathrm{N}^{15}$ of nitrate in groundwater from Long Island, New York.............. 118

21. Partial chemical analyses of groundwaters from four water districts in Nassau County, Long Island, New York. . . . . . . . . 119

22. Tritium ages of groundwater, Runnels County, Texas................ . . 134

23. Approximate tritium content of precipitation for $31^{\circ}$ to $33^{\circ} \mathrm{N}$. latitude and $100^{\circ}$ to $105^{\circ}$

W. longitude . . . . . . . . . . . 136

\section{ILLUSTRATIONS}

1. Nitrogen generation tube, modified from Ribbenberg (1946) and Balestrieri (1968) . . . . 13

2. Apparatus for purification of nitrogen gas . . . 14

3. Nitrate and $\delta N^{15}$ versus depth beneath a cotton field with no animal wastes. Soil sample location ( $k$ ) ( $p l s .1$ and 2). Samples stored nonfrozen. . . . . . . . . . .

4. Nitrate and $\delta N^{15}$ versus depth beneath a cotton field with no animal wastes. Soil sample location (1) (pls. I and 2). Samples stored frozen............. . . 28

5. Apparatus for collecting gaseous ammonia . . . . 31

6. Nitrate and $\delta N^{15}$ versus depth beneath barnyard with definite animal waste contribution of N. Soil sample location (d) (pls, 1 and 
Figure

$\underline{\text { Page }}$

7. $\delta \mathrm{N}^{15}$ and $\mathrm{NO}_{3}$ in soils from barnyards ( ) and septic tank laterals ( )........ 38

8. $\delta \mathrm{N}^{15}$ ranges of natural soil nitrate and animal waste nitrate (Runnels County, Texas) . . . . . . . . . . . . . .

9. Nitrate and $\delta N^{15}$ versus depth beneath a cotton field with no animal waste contribution of N. Soil sample location (c)......

10. Nitrate and $\delta N^{15}$ versus depth beneath cotton field with no animal waste contribution of $\mathrm{N}$. Soil sample location $(n)$.

11. Nitrate and $\delta N^{15}$ versus depth beneath turnroad with no animal waste contri-

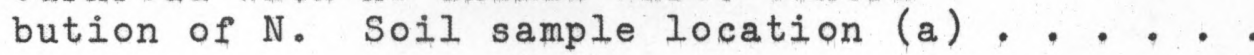

12. Nitrate and $\delta N^{15}$ versus depth beneath turnroad with no animal waste contribution of N. Soil sample location (o)

13. Nitrate and $\delta N^{15}$ versus depth beneath corn field with grazing cattle. Soil sample location (b).

14. Nitrate and $\delta N^{15}$ versus depth beneath corn field with grazing cattle. Soil sample location (h).

15. Nitrate, chloride, and $\delta N^{15}$ versus depth in "virgin" prairie soil. Soil sample location (e) ................

16. Decrease of total soil nitrogen with years of cultivation ................

17. $\delta \mathrm{N}^{15}$ of nitrate in groundwater from Runnels County, Texas................

18. $\delta \mathrm{N}^{15}$ of nitrate in groundwater from wells in cultivated fields compared to the $\delta \mathrm{N} I 5$ of natural soil nitrate and animal waste nitrate (Runnels County, Texas). . . . . . . 
19. $\delta N^{15}$ of nitrate in groundwater from wells near farmhouses, but not in barnyards compared to $\delta N^{15}$ of natural soil nitrate and animal waste nitrate (Runnels County, Texas).

20. $\delta \mathrm{N}^{15}$ of nitrate in groundwater from barnyard wells compared to $\delta N^{15}$ of natural soil nitrate and animal waste nitrate (Runnels County, Texas)........... 97

21. Increase of total soil nitrogen with increased clay content of several New York soils.

22. $\delta N^{15}$ of groundwaters from Macon County, Missouri, and $\delta N^{15}$ of groundwaters from Long Island, New York. . . . . . . . . 109

23. $\delta N^{15}$ of nitrate in groundwater from Macon County, Missouri, compared to the $\delta \mathrm{N}^{15}$ ranges of natural soil nitrate and animal waste nitrate from Runnels County, Texas . . . . III

24. Recharge to Magothy aquifer. . . . . . . . . 115

25. Enrichment of deuterium and tritium in liquid water during evaporation. . . . . . . 138

26. Tritium in groundwater and precipitation . . . 140

Plate

1. General soil association and soil sample location map, Runnels County, Texas. . . . . pocket

2. Location map for water samples and soil samples from southern Runnels County, Texas................. pocket

3. Location map for water samples from Macon County, Missouri....... . . . . . pocket

4. Location map for water samples from Queens and Nassau Counties, New York. . . . . . pocket 


\section{INTRODUCTION}

The study of nitrogen isotopes provides a method of monitoring the migration of nitrogenous compounds in biogeochemical cycles. As nitrogen compounds are altered chemically within a system the stable isotopes, $\mathrm{N}^{14}$ and $\mathrm{N}^{15}$, may undergo isotopic fractionation. If such fractionations are unique then nitrogen isotopes can be used to determine major sources of nitrate in natural systems.

More specifically, nitrogen isotopes can be used to determine sources and pathways of migration of nitrates to natural waters. Since the early $1950^{\prime} \mathrm{s}$, investigators have tried to trace the sources of nitrate in surface and ground waters. However, most investigators neither understood the complexities of the nitrogen cycle nor the number of nitrogen sources available for oxidation to nitrate. Their results were either indefinite or inaccurate. Viets and Hageman (1971) reviewed much of the literature concerning nitrates in groundwater.

The development of nitrogen isotope techniques for tracing nitrates in natural systems is of value for environmental health reasons as well as for strictly scientific considerations. Nitrates have been blamed for clinical and chronic methemoglobinemia (blue-babies). Methemoglobinemia occurs when nitrates in the gastrointestinal tract are reduced 
to nitrite. The nitrite is absorbed into the blood and oxidizes the ferrous iron of hemoglobin to ferric iron. The hemoglobin loses its ability to release oxygen to cells. Cell asphyxiation then occurs (Winton, Tardiff, and McCabe, 1971). The U. S. Public Health Service (U.S.P.H.S.) has set a recommended limit of 45 milligrams per liter (mg/l) nitrate for public water supplies to prevent methemoglobinemia. Gruener and Shuval (1970) observed, however, that the continual ingestion of low concentrations of nitrate produces chronic methemoglobinemia, an anemic condition. The U.S.P.H.S. limit of $45 \mathrm{mg} / \mathrm{I}$ nitrate for drinking water may be too high if widespread anemia results as large numbers of persons drink water with lower nitrate concentrations.

In laboratory studies with rats, a positive correlation has been made between nitrate and cancer (Wolf and Wasserman, 1972). Nitrite (one oxidation state below nitrate) reacting with a secondary amine forms a nitrosamine; some nitrosamines are carcinogenic. Alam et al. (1971a, 1971b), Asahina et al. (1971), Ayanaba et al. (1973), Challis (1973), Harington et al. (1973), Lijinsky and Epstein (1970), McCormick et al. (1973), and Verstraete and Alexander (1971) have studied various aspects of this problem. Some evidence suggests that an epidemiological correlation may exist between nitrate and cancer in humans. There appears to be a high incidence of cancer in Texans and Virginians who use water from 
shallow aquifer systems which may contain high nitrates (Everet, A. G., personal communication, November 1973), but no evidence has been presented to substantiate this hypothesis. Because of the potential health problem the major nitrate contributors to a water supply should be known. Legislators have attempted to regulate nitrogen fertilizer use, but most arguments against fertilizers have been based on environmentalists' rhetoric rather than on data. Nitrogen isotope studies may solve some of these problems.

To determine whether nitrogen isotope investigations are applicable to tracing nitrates in natural environments, it is necessary ( 1 ) to develop methods and confirm reproducible results in measuring the nitrogen isotope ratio of nitrates, (2) to study the pertinent nitrogen cycles to determine if there are unique isotopic ranges, (3) to identify the isotopic fractionations, and (4) to apply this information and these techniques in areas where the waters have been contaminated by nitrates. This dissertation deals with these four problems. 


\section{METHODS OF ANALYSIS}

Of the five nitrogen isotopes, $\mathrm{N}^{13}, \mathrm{~N}^{14}, \mathrm{~N}^{15}, \mathrm{~N}^{16}$, and $\mathrm{N}^{17}$, three are extremely unstable and hence do not exist in measurable quantities in natural systems. Half-lives of $\mathrm{N}^{13}, \mathrm{~N}^{16}$, and $\mathrm{N}^{17}$ are ten minutes, seven seconds, and four seconds respectively (Jansson, 1968). The stable isotopes are $\mathrm{N}^{14}$ and $\mathrm{N}^{15}$ of which N ${ }^{14}$ predominates; $99.632 \pm 0.002$ percent of nitrogen in the atmosphere is $\mathrm{N}^{14}$ (Junk and Svec, 1958; Nier, 1955). In other nitrogenous compounds, these percentages vary slightly because of isotopic fractionation. The variations of mass are measured on a gas-source mass spectrometer in which the sample is compared to atmospheric nitrogen, the standard. Another available standard is the tank nitrogen used by June and Svec (1958). A sample may be obtained from Dr. Svec at the Ames Laboratory, Ames, Iowa. Ammonium sulfate has also been used as a working standard (Commoner, 1970a; Edwards, 1973). The ratio of sample to standard is expressed in the accepted isotopic terminology as:

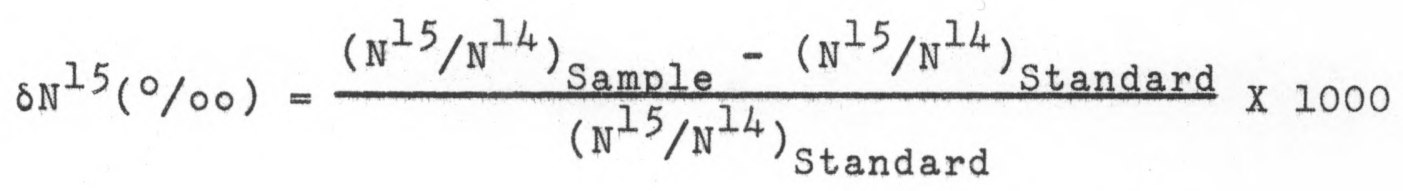

If $\mathrm{N}^{15}$ in the sample is enriched relative to $\mathrm{N}^{15}$ in the atmospheric nitrogen standard, the sample has a positive $\delta$ value; 
if relatively depleted in $\mathrm{N}^{15}$ the sample has a negative $\delta$ value.

Nitrogen in natural systems occurs as organic nitrogen (amides, amines, proteins, and amino acids), ammonia $\left(\mathrm{NH}_{3}\right)$, ammonium $\left(\mathrm{NH}_{4}{ }^{+}\right)$, nitrite $\left(\mathrm{NO}_{2}^{-}\right)$, nitrate $\left(\mathrm{NO}_{3}^{-}\right)$, and nitrogen gas $\left(\mathrm{N}_{2}\right)$. For isotopic analysis these compounds must be converted to nitrogen gas. Organic nitrogen is converted to ammonia by Kjedahl distillation. Nitrite and nitrate are reduced to ammonia with Devardas Alloy ( $50 \% \mathrm{Cu}, 45 \%$ $\mathrm{Al}$, and $5 \% \mathrm{Zn}$ ) and then distilled. The ammonia generated from either organic nitrogen or nitrite and nitrate is oxidized to nitrogen gas with sodium hypobromite. The nitrogen gas is then purified by circulation through a Cu-CuO furnace followed by circulation through a liquid nitrogen cold trap, thereby eliminating carbon dioxide, carbon monoxide, nitrous oxides, water vapor, and oxygen. The gas is analyzed by comparing the ratio of mass 29 to mass $28\left(\mathrm{~N}^{15} \mathrm{~N}^{14} / \mathrm{N}^{14} \mathrm{~N}^{14}\right)$.

Sample preparation and isotopic analysis of nitrate

Preparing and analyzing the nitrate samples are accomplished as follows.

a. Determine approximate concentration of nitrate with specific ion electrode (Orion Model No. 92-07). Treat aliquot containing less than $50 \mathrm{mg}$ of nitrate with $5 \mathrm{ml}$ of sulfamic acid to convert any nitrite in solution to nitrogen gas. 
Transfer sample to $500 \mathrm{ml}$ boiling flask.

The specific ion electrode for nitrate is used to determine the approximate concentration of the samples so that aliquots of the sample solutions have nitrate concentrations equal to or less than the nitrate in the standard $\mathrm{CaNO}_{3} \mathrm{H}_{2} \mathrm{O}$ $\left(50 \mathrm{mg} \mathrm{NO} 2\right.$ ) and $\mathrm{NH}_{4} \mathrm{Cl}(20 \mathrm{mg} \mathrm{NH})_{4}$ ) solutions. The various reactions are then complete, eliminating potential isotopic fractionation. Most aliquots had nitrate concentrations of approximately $30 \mathrm{mg} \mathrm{NO}{ }^{\circ}$

Sulfamic acid reacts with nitrite by the following reaction:

$$
\mathrm{NH}_{2} \mathrm{SO}_{3} \mathrm{H}+\mathrm{HNO}_{2} \leftarrow \mathrm{N}_{2}+\mathrm{H}_{2} \mathrm{SO}_{4}+\mathrm{H}_{2} \mathrm{O}
$$

The addition of sulfamic acid to eliminate nitrite was not necessary in this study because Kreitler (1972) found negligible levels of nitrite in the groundwaters of southern Runnels County, Texas.

b. Raise $\mathrm{pH}$ of solution to between 9.5 to 10.0 by adding powdered magnesium oxide $(\mathrm{MgO})$. Distill solution until 50 to $75 \mathrm{ml}$ of distillate are collected. Interfering nitrogen species are eliminated.

The distillation procedures are modifications of Bremner and Keeney (1966). Five hundred milliliter, three-necked and two-necked boiling flasks are used instead of the steam 
distillation apparatus recommended by Bremner and Edwards (1965). The $\mathrm{pH}$ of the solution is raised to 9.5 to 10.0 to convert all $\mathrm{NH}_{4}{ }^{+}$to $\mathrm{NH}_{3}$ and to breakdown any labile organic compounds to ammonia. Hydrolyzable organic nitrogen will ammonify at a nonpredictable rate with $\mathrm{pH}^{\prime} \mathrm{s}$ over 12 . A weak base, such as $\mathrm{MgO}$, maintains the $\mathrm{pH}$ in the desired range. Tests using 69 organic nitrogen compounds, including amino acids, purine, pirinudine derivatives, alkali labile compounds such as amides and hexosamines, demonstrate that the distillation method has a high specificity (Bremner and Keeney, 1966). For the present study, the nitrate can be separated from the rest of the nitrogen compounds common to soils.

c. Immerse tip of water-jacketed condenser into beaker containing $50 \mathrm{ml}$ of 0.1 normal $\mathrm{HCl}$. Add 5 grams of Devardas Alloy (75\% passing a 200-mesh screen, 100\% passing a 100-mesh screen) through a sidearm on the flask and immediately restopper. Stir solution for 15 to 20 minutes without heating to reduce nitrate to ammonia.

Devardas Alloy ( $50 \% \mathrm{Cu}, 45 \% \mathrm{Al}$, and $5 \% \mathrm{Zn}$ ) is a reducing agent which reacts with nitrate to form ammonia. If the Devardas Alloy is not ground to a fine powder, reduction of nitrate to ammonia may be incomplete. Without complete reduction, an isotopic fractionation occurs.

Three groundwater samples and three soil samples had 
negative $\delta N^{15}$ values (table 1$)$, whereas all other samples. from this study had positive values. Slight variations in the methods of collection or analysis may have caused these negative values. The first analyses of all six negative samples were made using a coarse-grained Devardas Alloy. When resampled and prepared with fine-grained Devardas Alloy, all the soil and water nitrate samples were positive.

The negative $\delta N^{15}$ groundwater samples were collected from deserted barnyard wells which had not been pumped for at least one year. Previous sampling showed high nitrate concentrations (Kreitler, 1972). Upon resampling, the wells were pumped from three to four hours, and a fine-grained Devardas Alloy was used in the analyses. The $\delta N^{15}$ values as well as the nitrate concentrations drastically increased with the second analysis. The negative $\delta \mathrm{N}^{15}$ and the lower nitrate concentrations may indicate chemical reactions occurring in the well bore or biologic or nonbiologic denitrification, but more likely they indicate an incomplete reaction caused by coarsegrained Devardas Alloy. This incomplete reaction would preferentially select isotopically light $\mathrm{NO}_{3}$.

Upon reanalyzing the three soil samples with negative $\delta N^{15}$ values, the same sample or a soil sample one foot above or below the depth of the original sample was used. With the second group of analyses the soil nitrate of the samples had positive $\delta N^{15}$ values. Analyses of the first set of samples 
Table 1. Experimental fractionation of groundwater nitrate and soil nitrate by coarse-grained Devardas Alloy

\section{Groundwater}

\begin{tabular}{ccccc}
\hline \hline Well No. & $\begin{array}{l}\text { Frequency } \\
\text { of Pumping }\end{array}$ & $\begin{array}{c}\mathrm{NO}_{3} \\
(\mathrm{mg} / \mathrm{I})\end{array}$ & $\begin{array}{c}\delta \mathrm{N}^{15} \\
(\% / 00)\end{array}$ & Devardas Alloy \\
\hline 141 & not pumped & 141 & -3.1 & coarse-grained \\
141 & pumped & 211 & +7.5 & fine-grained \\
388 & not pumped & 63 & -6.0 & coarse-grained \\
388 & numped & 978 & +10.3 & fine-grained \\
1004 & not pumped & 186 & -1.8 & coarse-grained \\
1004 & pumped & 250 & +10.4 & fine-grained \\
\hline
\end{tabular}

Soils

\begin{tabular}{|c|c|c|c|c|c|}
\hline $\begin{array}{l}\text { Loca- } \\
\text { tion }\end{array}$ & $\begin{array}{l}\text { Depth } \\
(f t)\end{array}$ & Owner & Land Use & $\begin{array}{c}\delta N^{15} \\
(0 / 00)\end{array}$ & Devardas Alloy \\
\hline o & 1 & Beimer & turnroad & -0.2 & coarse-grained \\
\hline o & 2 & Beimer & turnroad & +6.7 & fine-grained \\
\hline $\mathrm{n}$ & 3 & Beimer & $\begin{array}{l}\text { cotton } \\
\text { field }\end{array}$ & -2.0 & coarse-grained \\
\hline $\mathrm{n}$ & 3 & Beimer & $\begin{array}{l}\text { cotton } \\
\text { field }\end{array}$ & +8.6 & fine-grained \\
\hline $\mathrm{n}$ & 6 & Beimer & $\begin{array}{l}\text { cotton } \\
\text { field }\end{array}$ & -0.5 & coarse-grained \\
\hline $\mathrm{n}$ & 5 & Beimer & $\begin{array}{l}\text { cotton } \\
\text { field }\end{array}$ & +6.2 & fine-grained \\
\hline
\end{tabular}

1 - Locations in Appendix 2 and Plate 2.

2 - Locations in Appendix 3 and Plate 2. 
were made with a soil slurry of soil and water and with coarse-grained Devardas Alloy. In the analyses of the second samples, the soil slurries were centrifuged to separate the soil and water and fine-grained Devardas Alloy was used. Interference of clay minerals in the soil slurry did not cause the observed isotopic fractionations. Keeney and Bremner (1966) analyzed soil slurries for ammonium, nitrate, and nitrite, and found that their direct distillation techniques were within $1 \mathrm{mg} / \mathrm{l}$ of their extraction and distillation method. I conclude that the negative $\delta N^{15}$ values can be attributed to the coarse-grained nature of the Devardas Alloy and not the duration of well pumping nor the use of a soil slurry.

d. Redistill the solution until $75 \mathrm{ml}$ of distillate are collected in the 0.1 normal HCl solution. Titrate the acidic ammonium solution with 0.1 normal $\mathrm{NaOH}$ to determine the amount of nitrate in the original sample. As soon as the end point is reached, immediately reduce the $\mathrm{pH}$ to 2 by adding concentrated $\mathrm{HCl}$ to prevent loss of ammonia.

The second distilation is collected in $50 \mathrm{ml}$ of 0.1 normal $\mathrm{HCl}$ and is titrated with $50 \mathrm{ml}$ of 0.1 normal $\mathrm{NaOH}$. The distilled ammonia absorbs an equal molar quantity of $\mathrm{H}^{+}$to form ammonium by the following reaction:

$$
\mathrm{NH}_{3}+\mathrm{H}^{+} \leftarrow \mathrm{NH}_{4}^{+}
$$


The $\mathrm{NaOH}$ is titrated against the excess of $\mathrm{H}^{+}$to determine the distilled ammonia or the original nitrate concentration. The number of moles of $\mathrm{NH}_{3}$ distilled is calculated by the following equation:

$$
\mathrm{mNO}_{3} \text { or } \mathrm{mNH}_{3}=(\mathrm{ml} \times 0.1 \mathrm{~N} \mathrm{HCl})-(\mathrm{ml} \times 0.1 \mathrm{~N} \mathrm{NaOH})
$$

The solutions of 0.1 normal $\mathrm{HCl}$ and 0.1 normal $\mathrm{NaOH}$ used are too acidic and too basic respectively, causing a loss in precision. The relatively concentrated solution ( 0.1 normal) of $\mathrm{HCl}$ was used to insure that all ammonia was absorbed, but solutions of 0.05 normal would have been adequate. This concentration of $\mathrm{H}^{+}$would have covered the range of ammonia concentrations analyzed with a resulting increase in precision. Calculations of nitrate concentrations by the titration method were used in preference to nitrate activities observed with an ion electrode because of the interference of $\mathrm{HCO}_{3}{ }^{-}$ and $\mathrm{Cl}^{-}$in the electrode measurement. The distillation technique is not subject to interference from either organic or inorganic compounds (Bremner and Keeney, 1966).

After the second distillation, the apparatus is disassembled and cleaned with Alconox, distilled water, and reagent-grade ethanol. This cleaning prevents the cross contamination of samples. Cleaning techniques are based on comments from Bremner and Edwards (1965, p. 507). 
e. Concentrate the solution to 5 to $10 \mathrm{ml}$ by heating on a hot plate at $70^{\circ} \mathrm{C}$ to $80^{\circ} \mathrm{C}$.

Acidic ammonia chloride solutions are never boiled so as to avoid the loss of ammonia. Similarly, samples are never evaporated to dryness because of the potential for isotopic fractionation.

f. Add the ammonium chloride solution (less than 25 $\mathrm{mg} \mathrm{NH}_{4}$ ) to the large volume side of a dog-legged tube and add approximately $5 \mathrm{ml}$ of sodium hypobromite to the small side arm (fig. 1). Attach the sample reaction tube to the nitrogen purification vacuum system (fig. 2). Freeze, evacuate, and thaw the two solutions to degass any atmospheric nitrogen from them. After the third thawing, rotate the small side $180^{\circ}$ and drain the sodium hypobromite-iodate solution into the ammonium chloride solution. The resulting reaction will liberate nitrogen gas.

The freeze-thaw method for degassing the $\mathrm{NH}_{4} \mathrm{Cl}$ solution eliminates atmospheric nitrogen. Table 2 shows the effectiveness of this technique. Atmospheric nitrogen contamination of the sample can be determined by measuring the argon peak with the mass spectrometer. Argon present above background levels is the result of atmospheric contamination. The percentage of contamination can be calculated by comparing the argon 40 peak-nitrogen 28 peak ratio of the sample to the argon 40 peak-nitrogen 28 peak ratio of the standard. The 


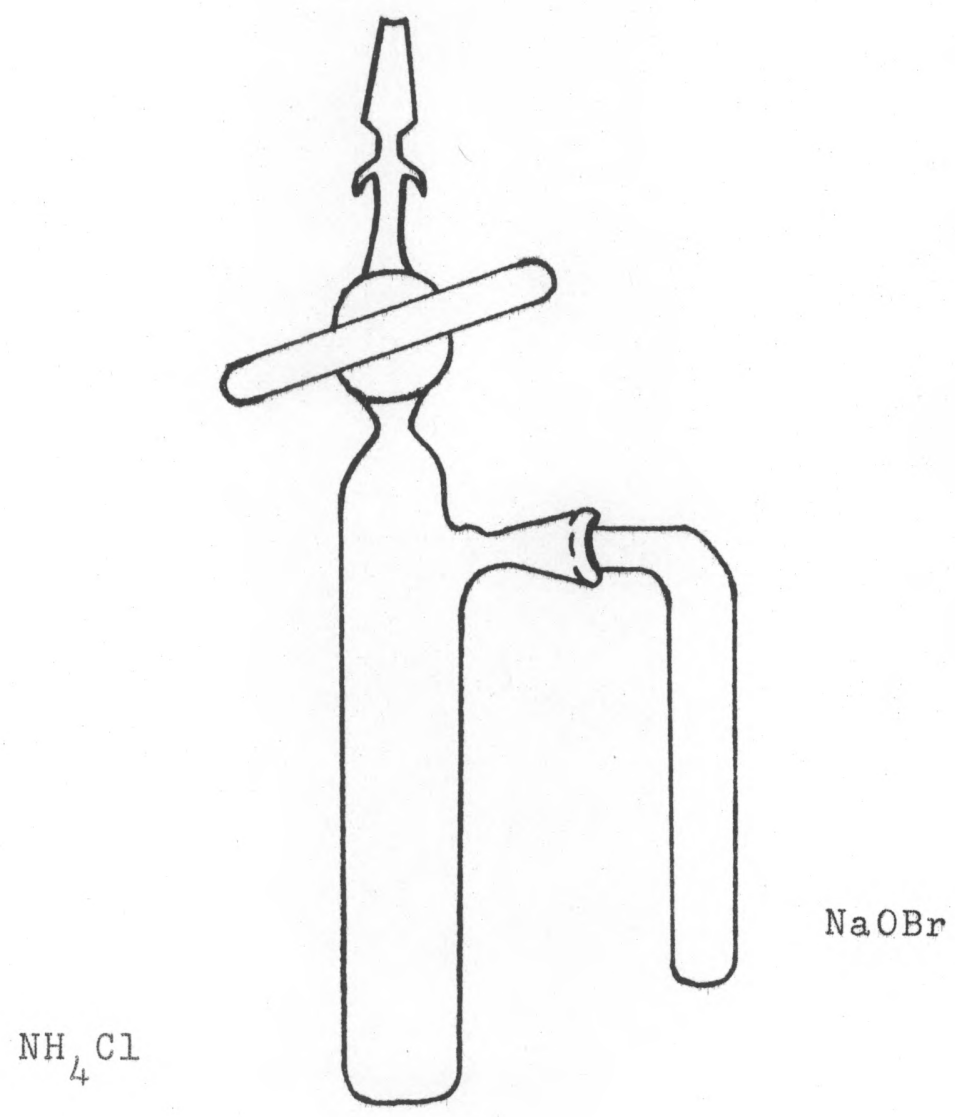

Figure 1. Nitrogen generation tube, modified from Rittenberg (1946) and Balestrieri (1968)。 


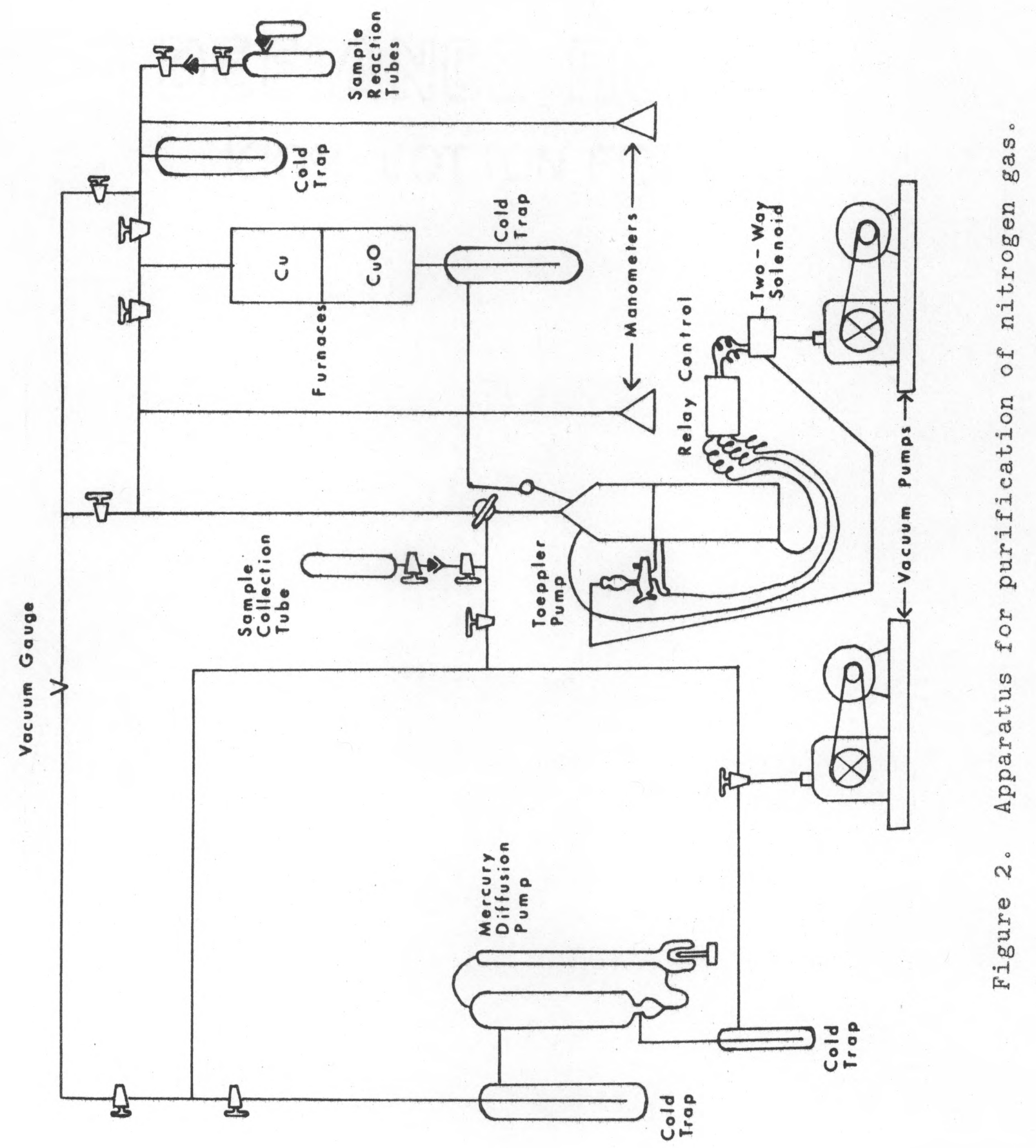


Table 2. Effectiveness of degassing sample of atmospheric nitrogen by freeze-thaw technique as analyzed by a mass spectrometer (from Balestrieri, 1968).

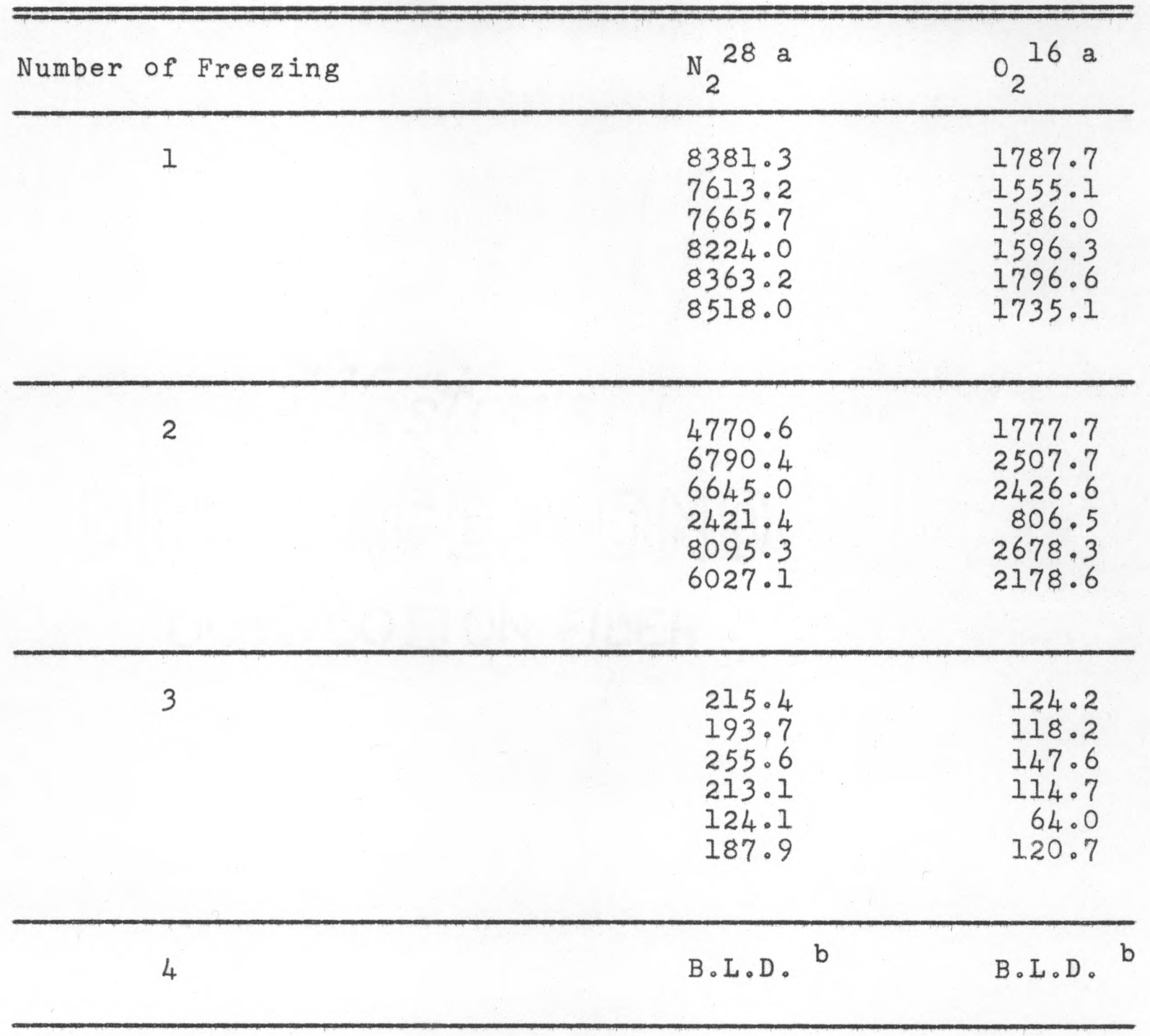
$a=$ arbitrary units
$b=$ below limits of detection 
oxygen 30 peak cannot be used for calculating the amount of contamination since part of the oxygen may be derived from the hypobromite reaction (Balestrieri, 1968). Because of the relatively large $\mathrm{NH}_{4}$ samples used in this study, atmospheric nitrogen contamination was considered insignificant and the argon peak was not checked. The argon peak should be checked for nitrogen isotope studies where the concentration of the nitrogen species is very low (such as surface water where the $\mathrm{NO}_{3}$ concentrations rarely exceed $1 \mathrm{mg} / \mathrm{l}$ ).

A dry-ice and M-I7 (organic solvent) cold trap is used for freezing instead of a liquid nitrogen cold trap because the liquid nitrogen cracks the Pyrex glass of the reaction vessel by the rapid expansion of freezing water. Dry-ice cold traps do not cause this problem.

Sodium hypobromite reacts with ammonium chloride liberating nitrogen gas by the following reaction:

$$
2 \mathrm{NH}_{3}+3 \mathrm{NaOBr} \longleftrightarrow 3 \mathrm{NaBr}+3 \mathrm{H}_{2} \mathrm{O}+\mathrm{N}_{2}
$$

The use of sodium hypobromite carries two inherent problems. One of these problems is that sodium hypobromite tends to decompose and liberate oxygen (Bremner et al., 1966):

$$
2 \mathrm{NaOBr} \leftarrow 2 \mathrm{NaBr}+\mathrm{O}_{2}
$$

This problem is eliminated by using an excess of $\mathrm{NaOBr}$ in the 
oxidation reaction. If the solution remains yellow (the initial color of the $\mathrm{NaOBr}$ solution) after the reaction, an excess of $\mathrm{NaOBr}$ is present and the reaction has gone to completion.

The second problem is that the oxidation reaction is not quantitative. Bremner et al. (1966), Riley et al. (1954), and Capindale and Tomlin (1957) all observed the formation of nitrous oxide as well as nitrogen gas. Nitrous oxide is eliminated by freezing in a liquid nitrogen cold trap. Erratic isotopic fractionation caused by the incomplete oxidation is not present. The reproducibility of standard $\mathrm{CaNO}_{3} \mathrm{H}_{2} \mathrm{O}$ and $\mathrm{NH}_{4} \mathrm{Cl}$ solutions (table 3 ) confirms this.

g. Circulate the nitrogen gas through the hot $\mathrm{Cu}$ $\left(\mathrm{T}=400^{\circ} \mathrm{C}\right)$, hot $\mathrm{CuO}\left(\mathrm{T}=800^{\circ} \mathrm{C}\right)$, liquid nitrogen cold trap, vacuum system for four hours to eliminate any oxygen, carbon monoxide, organics (carbonaceous and nitrogenous), and any gaseous oxides of nitrogen. Collect the purified $\mathrm{N}_{2}$ in an evaculated sample tube.

$\mathrm{Cu}-\mathrm{CuO}$ furnaces are used for gas cleaning because of possible contamination by carbon monoxide (Hoering, To, personal communication, January 1972). Carbon monoxide nominally has the same atomic weight as nitrogen gas and would, therefore, introduce an erratic error. The copper reacts with free oxygen to form a CuO precipitate. The copper oxide oxidizes carbon monoxide to carbon dioxide, which subsequently "freezes 
Table 3. $\delta N^{15}$ reproducibility of analyses of replicate $\mathrm{CaNO}_{3} \mathrm{H}_{2} \mathrm{O}$ and $\mathrm{NH}_{4} \mathrm{Cl}$ solutions

\begin{tabular}{|c|c|c|}
\hline & $\begin{array}{c}\mathrm{CaNO}_{3} \mathrm{H}_{2} \mathrm{O} \\
\mathrm{SN}^{15}(0 / 0 \mathrm{O})\end{array}$ & $\begin{array}{c}\mathrm{NH}_{4} \mathrm{Cl} \\
\delta \mathrm{N}^{15}(0 / 00)\end{array}$ \\
\hline & $+1 \cdot 30$ & +1.64 \\
\hline & +0.97 & +0.55 \\
\hline & +0.58 & +0.95 \\
\hline & +0.54 & $+3 \cdot 30$ \\
\hline & +0.72 & +1.17 \\
\hline & +1.49 & +0.36 \\
\hline & +0.69 & +1.00 \\
\hline & $+2 \cdot 40$ & \\
\hline & +1.20 & \\
\hline & +0.47 & \\
\hline Number samples & 10 & 7 \\
\hline Mean $\delta N^{15}(0 / 00)$ & +1.04 & +1.22 \\
\hline Standard deviation $(0 / 00)$ & 0.59 & 1.06 \\
\hline
\end{tabular}


out" in the liquid nitrogen cold trap. The furnace temperatures were obtained from Hoering (1955). The circulation time of four hours was based on work of Myaka and Wada (1967). The mass spectrometer trace of the nitrogen samples did not drift, which would have indicated possible contamination. The circulation of the nitrogen gas for one hour would probably be sufficient. Myaka and Wada (1971) circulated nitrogen gas for only one hour using a molecular sieve method of gas transfer.

h. Determine the nitrogen isotope ratio with a double collector, gas source, mass spectrometer, using atmospheric nitrogen as a standard.

Validity of $\delta \mathrm{N}^{15}$ data

The validity of this study depends on both accuracy ${ }^{1}$ and precision ${ }^{2}$ of the values obtained for $\delta N^{15}$. First, the measurement of nitrogen isotopes with the mass spectrometer must be demonstrated to be correct; second, the techniques used for sample preparation must be both accurate and precise.

The precision of the mass spectrometer and thus the precision of the standard is determined by comparing four

${ }^{I}$ Accuracy is deviation of the observed value from the absolute value.

${ }^{2}$ Precision is the degree to which analyses of identical samples can be reproduced. 
atmospheric nitrogen samples to another atmospheric sample (table 4). Little isotopic variation was detected among samples collected at different locations and at different times. Little isotopic variation exists among these samples and the atmospheric nitrogen analyzed by Junk and Svec (1958). Kent Murman (personal communication, June 1973) has found only small isotopic variation among atmospheric nitrogen samples. Accuracy in stable isotope mass spectrometry is only relative because samples are compared to a standard. An inter-laboratory correlation of standards must be made, because isotopic measurements by one researcher are of reduced value if they cannot be duplicated in another laboratory. If the mass spectrometer used in this study measured the absolute abundance of $\mathrm{N}^{15}$ in the atmosphere at any other value than 0.3663 atom-percent, then all other measurements would deviate by a similar amount. Therefore, it is desirable to compare results with another laboratory. This was accomplished by determining the $\delta \mathrm{N}^{15}$ value of a sample measured on another mass spectrometer, Dr. Harry Svec, Ames Laboratory, University of Iowa, kindly sent to me a flask of Mathewson pre-purified nitrogen tank gas which he had previously analyzed. The average atmospheric nitrogen sample (Ames, Iowa air) of Junk and Svec (1958) was 3.01\% heavier than their Mathewson pre-purified nitrogen tank gas. I found that atmospheric nitrogen from Austin, Texas, was $2.870 / 00$ to $2.92 \%$ heavier than the same 


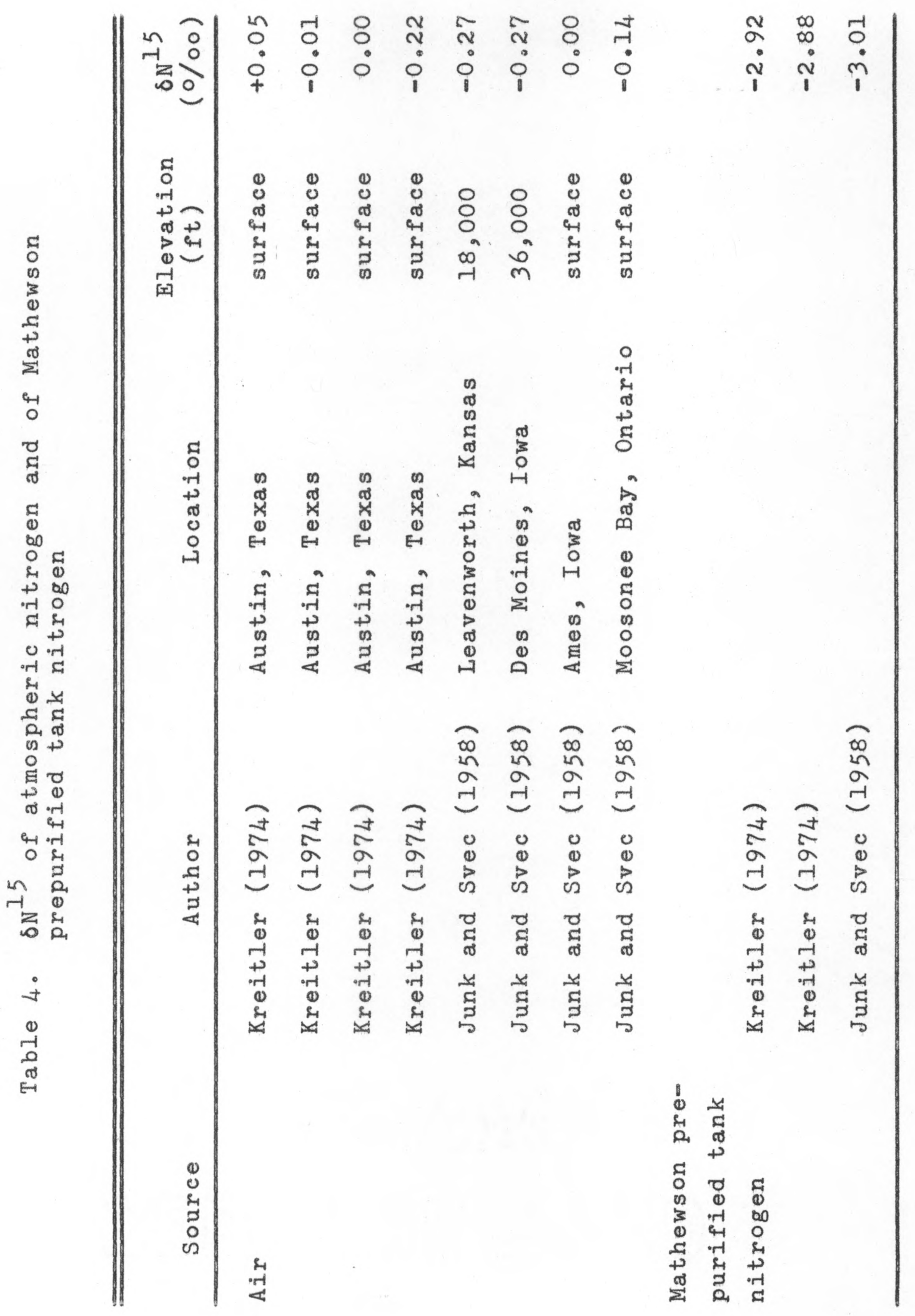


Mathewson pre-purified nitrogen tank gas from the same tank used by Junk and Svec in 1958 (table 4, p, 21). This is a difference of only $0.11 \% / 00$ which is within the precision of the mass spectrometer. It is assumed, therefore, that the standards used in this study are accurate.

To check the reproducibility of the sample preparation techniques, I analyzed ten samples of $\mathrm{NaNO}_{3}$ solution and seven samples of $\mathrm{NH}_{4} \mathrm{Cl}$ solution (table 3, p. 18). The $\mathrm{NH}_{4} \mathrm{Cl}$ samples had a mean $\delta N^{15}$ of $+1.22 \%$ with a standard deviation of $1.060 / 00$. The $\mathrm{NaNO}_{3}$ samples had a mean $\delta \mathrm{N}^{15}$ of $+1.04 \% 00$ with a standard deviation of $0.590 / 00$. Eight samples of $\left(\mathrm{NH}_{4}\right)_{2} \mathrm{SO}_{4}$ analyzed by Commoner (1970a) had a mean $6 \mathrm{~N}^{15}$ of $+0.71 \% 00$ and a standard deviation of $1.21 \% 0$ (table 5). This is in close agreement with my $\mathrm{NH}_{4} \mathrm{Cl}$ and $\mathrm{NaNO}_{3}$ data. Experimental error is approximately $\pm 10 / 00$.

\section{Collection of soil samples}

I collected 54 soil samples ( 1 to $2 \mathrm{Kg}$ ) every foot to depths of five to ten feet from nineteen holes drilled with a rotary air drilling rig. Samples were stored in an air conditioned room $\left(25^{\circ} \mathrm{C}\right)$ before the summer of 1973 , and in a freezer locker at a meat packing plant (below $0^{\circ} \mathrm{C}$ ) from the summer of 1973 until the fall of 1973. I made no attempt to adjust the soil moisture content or to heat the soils as is done in soil incubation studies. 
Table 5. $\delta N^{15}$ reproducibility of analyses of replicate $\mathrm{KNO}_{3}$ and $\left(\mathrm{NH}_{4}\right)_{2} \mathrm{SO}_{4}$ solutions (from Commoner, 1970a)

\begin{tabular}{|c|c|c|}
\hline . & $\begin{array}{c}\mathrm{KNO}_{3} \\
\mathrm{SN}^{15} \\
(\% / 00)\end{array}$ & $\begin{array}{c}\left(\mathrm{NH}_{4}\right)_{2} \mathrm{SO}_{4} \\
\mathrm{\delta N}^{\mathrm{I}} 5 \\
(0 / 00)\end{array}$ \\
\hline & -2.20 & -1.62 \\
\hline & +0.54 & +1.62 \\
\hline & +3.50 & +1.62 \\
\hline & +0.54 & +0.80 \\
\hline & $+1 \cdot 30$ & +0.30 \\
\hline & +1.10 & +1.90 \\
\hline & & 0.00 \\
\hline & & 0.00 \\
\hline Number samples & 6 & 8 \\
\hline Mean $\delta N^{15}(0 / 00)$ & +0.87 & +0.71 \\
\hline Standard deviation $(0 / 00)$ & 1.12 & 1.21 \\
\hline
\end{tabular}


Samples were leached overnight with deionized or distilled water. After decanting the clear liquid, the soil slurry was centrifuged for maximum recovery of the nitrate solution.

Edwards (1973) and Hauck (1973) questioned the use of stable nitrogen isotopes as a quantitative tool in soil nitrogen studies. Hauck (1973) objected specifically to the nitrogen isotope work of Kohl et al. (1971) because of their quantitative results based on a pacity of data.

Edwards (1973) opposed the use of stable nitrogen isotopes in soil nitrogen studies because of the lack of precision among the various authors caused by different times of incubation. Incubation is a method which is used to stimulate the oxidation of soil humus in the laboratory and to generate enough nitrate for nitrogen isotope analysis, With one method of incubation the water moisture content of the soil is raised to $50 \%$ of its water holding capacity and the soil is heated to approximately $30^{\circ} \mathrm{C}$ (Bremner and Tabatabai, 1973). Analyses of 10 replicate soil samples incubated for two weeks by Edwards (1973) had a mean $6 \mathrm{~N}^{15}$ value of $3.54 \%$ with a standard deviation of $0.76 \%$. A 22 week incubation of soils yielded $\delta N^{15}$ values of nitrate which, in respect to atmospheric $\mathrm{N}_{2}$, had both negative and positive results (Bremner and Tabatabai, 1973). Kohl et al. (1971) found that $\mathrm{NO}_{3}$ from "virgin" soil had a $\delta N^{15}$ of $+13 \%$. However, neither incubation time nor 
soil sample location were stated in the Kohl et al. (1971) report. Edwards (1973) suggested that if scientists use a constant incubation period, results will be more reproducible.

The lack of reproducibility of data as reported by Edwards (1973), Bremner and Tabatabai (1973), and Kohl et al. (1971) has not been a problem in this study because incubation was not used. The consistency of the $8 N^{15}$ values of nitrate from the soils shows that no significant experimental error was introduced.

In mort of the $\delta N^{15}$ profiles (e.g., fig. 3) the $\delta N^{15}$ values remain constant with depth, indicating that differential incubation has not taken place in the laboratory. In the deeper part of the soil profiles (deeper than one meter) insufficient organic nitrogen and nitrifying bacteria will prevent incubation. In the upper meter the soils are biologically active and should have adequate concentrations of or ganic nitrogen for mineralization. Conceivably, accidental incubation by storage at room temperature may have occurred with the shallow samples, but the consistency of $\delta \mathrm{N}^{15}$ with depth suggests that this has not happened. Owing to the low nitrate concentrations the entire soil sample was used for the initial analysis. Therefore, replicate samples could not be run.

The $\delta N^{15}$ of nitrates from similar soil environments 
remains in the same range regardless of whether the soil samples were stored frozen or at room temperature. Figure 3 represents $\delta \mathrm{N}^{15}$ values of nitrate from nonfrozen soils, whereas Figure 4 represents $\delta N^{15}$ values of nitrate from frozen soils. There is no appreciable isotopic difference. Again, incubation of the unfrozen samples has not occurred. The $\delta N^{15}$ values for the soil nitrates are considered valid because preparation techniques, collecting techniques, and mass spectrometry show good reproducibility.

\section{Collection of water samples}

Water samples were collected in collapsible one quart polyethylene bottles. Most samples were from frequently pumped wells. For this reason, most wells were not pumped more than five to ten minutes prior to the collection of the sample. Infrequently used wells were pumped for at least one hour before samples were collected. Bailed samples were taken from wells without pumps.

Samples were stored untreated at room temperature for periods of a few days to more than one year. No mercurial compounds or acids were added to inhibit algal growth. Table 6 shows the analyses of duplicate samples stored for different intervals of time. Water samples $865 \mathrm{~b}$ and $865 \mathrm{c}$ showed no appreciable isotopic variation within three months. Analysis after storage for one year showed a change in $\delta N^{15}$ (e.g., 


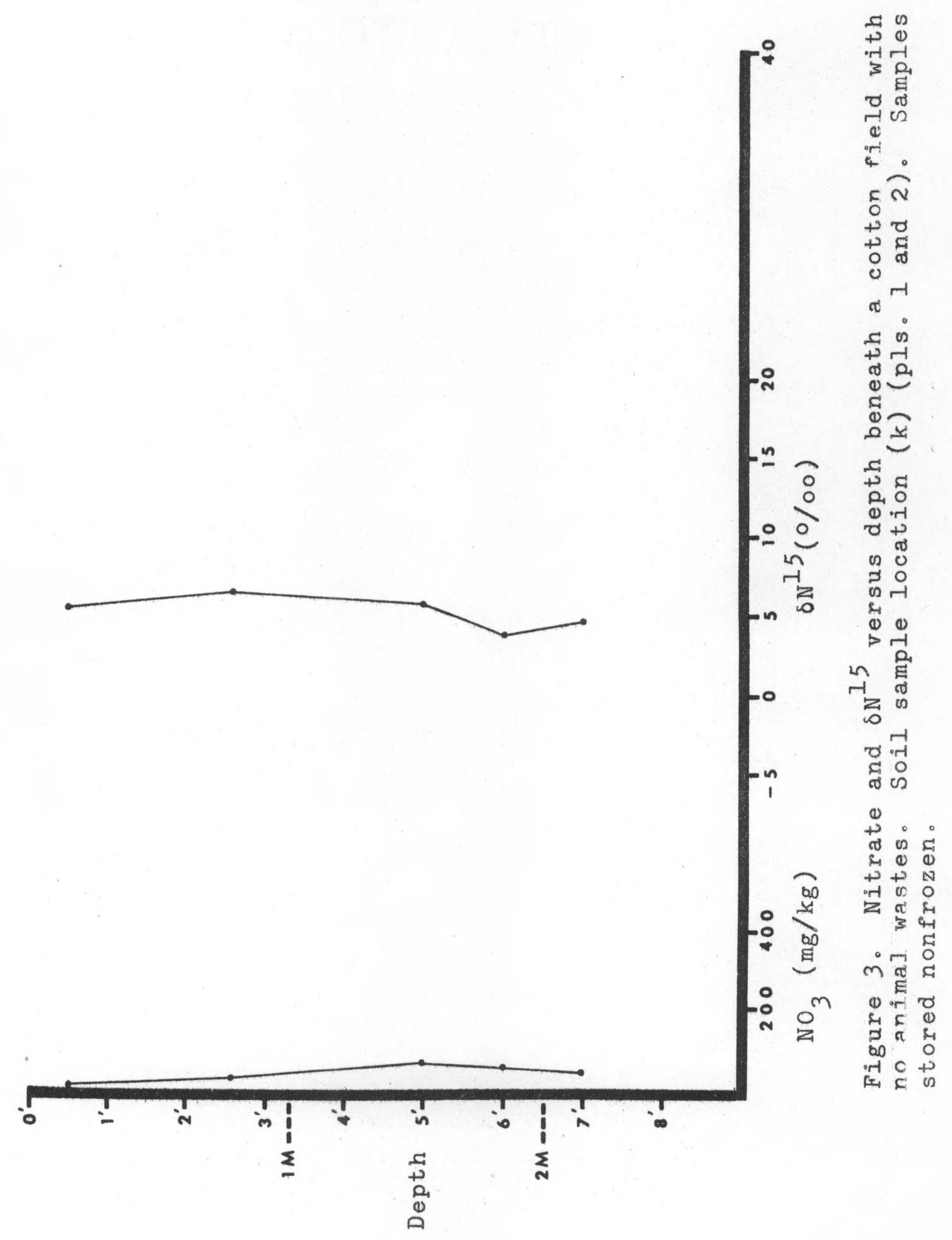




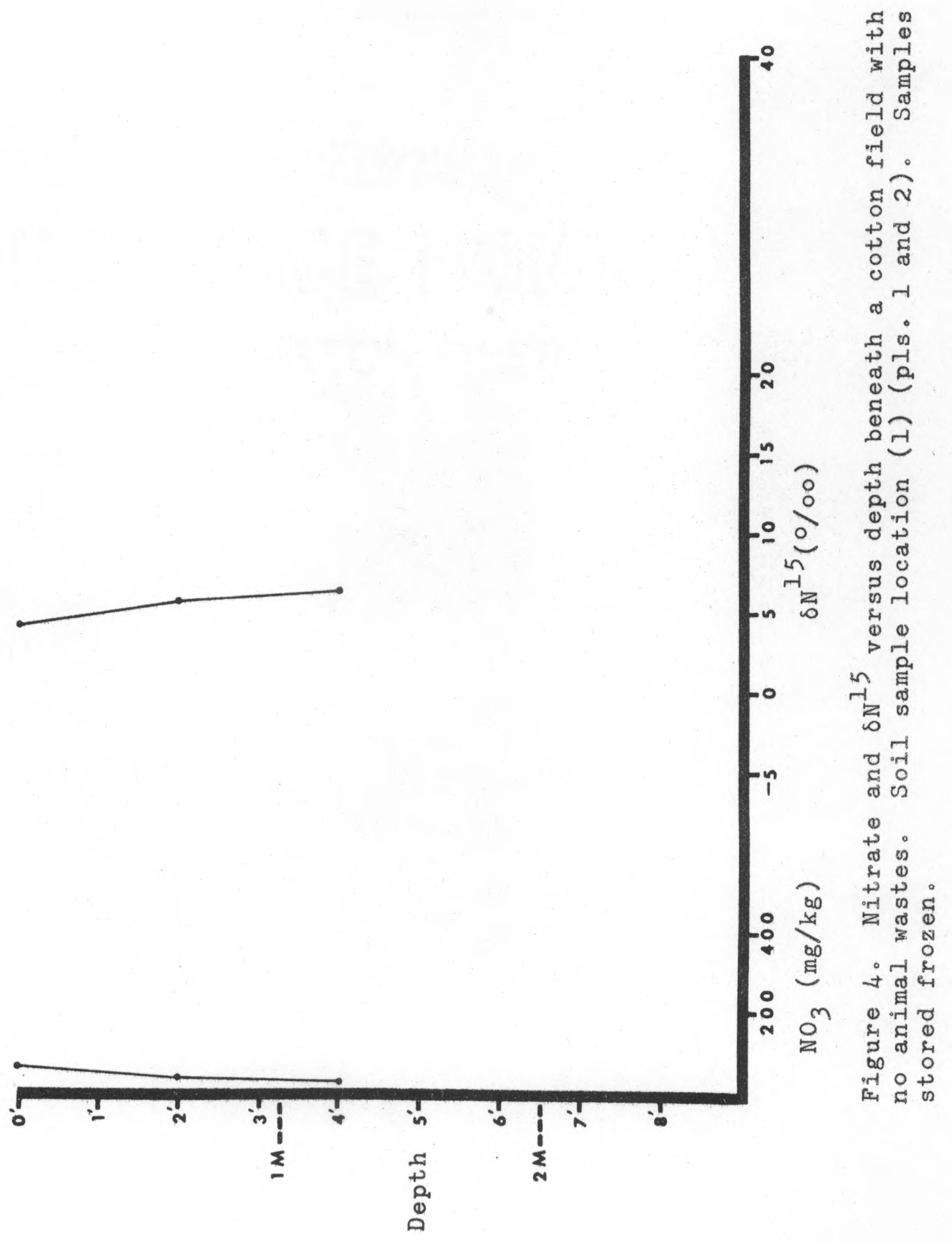


Table 6. $\delta N^{15}$ reproducibility of analyses of replicate samples of groundwater nitrate

\begin{tabular}{cccc}
\hline $\begin{array}{c}\text { Sample } \\
\text { Number }\end{array}$ & $\begin{array}{c}\delta N^{15} \\
(0 / 00)\end{array}$ & $\begin{array}{c}\text { Time Interval } \\
\text { Between Analyses }\end{array}$ & $\begin{array}{c}\text { Difference } \\
(0 / 00)\end{array}$ \\
\hline $865 b$ & +13.0 & 3 months & 0.2 \\
$865 \mathrm{c}$ & +13.2 & & 0.7 \\
$369 \mathrm{a}$ & +7.0 & 1 year & 3.1 \\
$369 \mathrm{~b}$ & +7.7 & 1 year & 1.5 \\
$1034 \mathrm{a}$ & +12.0 & & \\
$867 \mathrm{a}$ & +8.9 & 1 year & \\
$867 \mathrm{~b}$ & +10.4 & & \\
\hline
\end{tabular}


water samples 369,867 , and 1034). Storage of a few months does not cause significant isotopic variation, but storage for long periods of time is not recommended.

\section{Collection of ammonia gas samples}

I collected and analyzed three gaseous ammonia samples in an attempt to determine the isotopic fractionation controlling the $\delta N^{15}$ range of nitrate from animal waste. Ammonia constitutes $94 \%$ to $98 \%$ of the nitrogenous compounds evaporating from barnyards. Certain amines represent the remaining $2 \%$ to $6 \%$ of volatile nitrogen compounds (Mosier et al., 1973). The small addition of volatile amines is assumed to have little effect on the isotopic composition of the gaseous ammonia collected.

The gases were collected by placing a one-gallon plastic bucket over soil freshly saturated with cow urine. A plastic hose ran from the top of the bucket to a flask containing a 0.1 normal hydrocloric acid solution. Another hose ran from the flask to a small vacuum pump (fig.5). Gases volatilizing from the urine-soaked ground were pumped through the acid solution, and ammonia was trapped in the solution. Gas was collected from each site for approximately two hours. Samples of the urine-soaked soils were then collected and nitrate leached from these soils was subjected to $\mathrm{N}^{15} / \mathrm{N}^{14}$ analysis. 


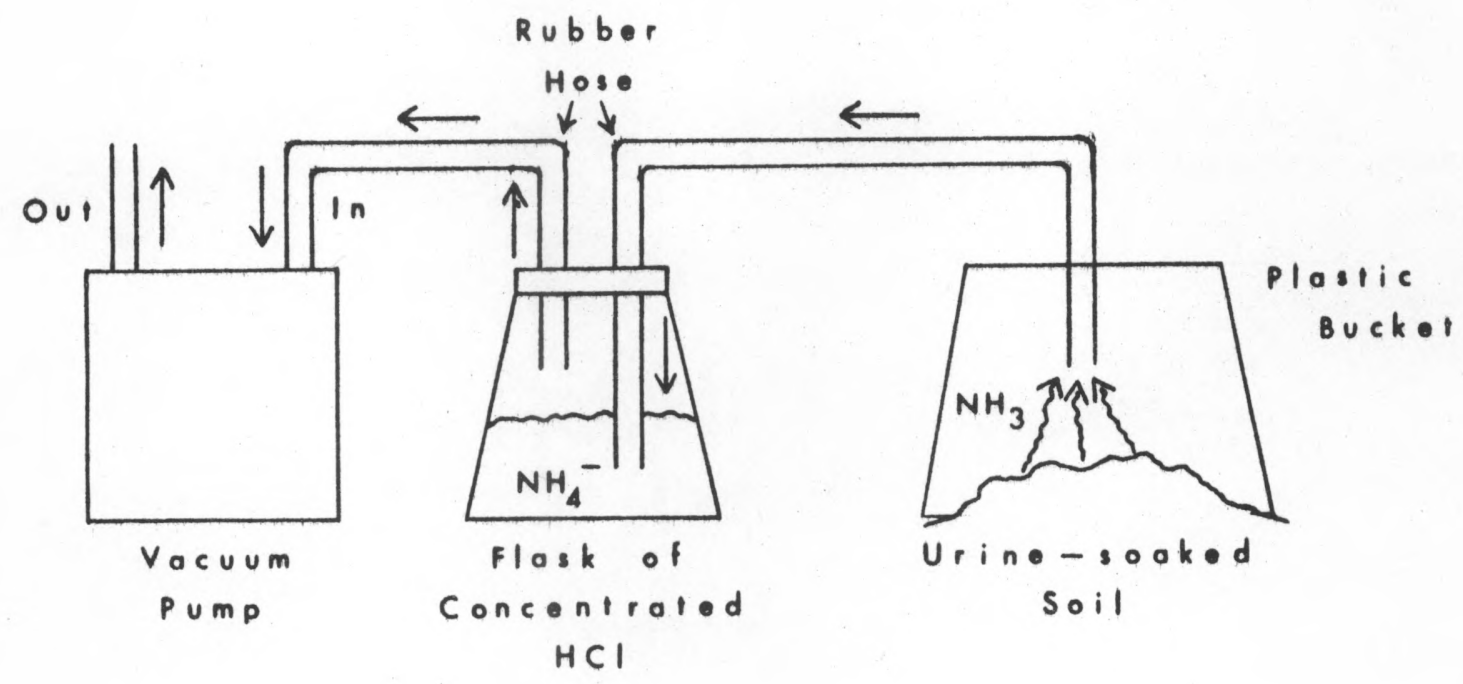

Figure 5. Apparatus for collecting gaseous ammonia. 
$\delta N^{15}$ OF SOIL NITRATE, SOUTHERN RUNNELS COUNTY, TEXAS

Alternate methods of study

In order to use nitrogen isotopes to trace groundwater nitrate, the nitrogen isotope geochemistry of the soil system must be understood. Four approaches can be taken: (1) study the isotopic fractionations of specific reactions, e.g., nitrification; (2) identify the $\delta N^{15}$ values of all the nitrogen species in a closed system; (3) analyze the $\delta N^{15}$ of nitrogen from different sources, for example, the $\delta \mathrm{N}^{15}$ of the nitrogen in fertilizer or the nitrogen in animal waste material; and (4) identify the $\delta \mathrm{N}^{15}$ of $\mathrm{NO}_{3}$ from different soil environments. Only the fourth approach is considered appropriate for this study; the other three are inappropriate because they do not help in tracing nitrate in groundwater to its source.

The first approach, the study of isotopic fractionations of specific reactions, is needed for a complete understanding of the nitrogen cycle in the soils. The work of Hoering and Ford (1960) on nitrification, Wellman, Cook, and Krouse (1968) on denitrification, Myaka and Wada (1971) on nitrification and denitrification, and Delwiche and Steyn (1970) on nitrification, nitrogen fixation, nutrient assimilation, and ion-exchange capacity in soils, are all valuable pieces of research. However, these studies were simplified, controlled experiments, and the applicability of their data to natural systems is difficult to evaluate. 
The second approach, the identification of the $\delta \mathrm{N}^{15}$ values of all the nitrogen species in a closed system, has many of the same problems as the first approach. The $\delta N^{15}$ values of the nitrogen species cannot be effectively compared to the $\delta \mathrm{N}^{15}$ of $\mathrm{NO}_{3}$ in groundwater, nor can the multitude of organic nitrogen species, as well as ammonium, nitrite, and nitrate be reproducibly separated and analyzed isotopically. The advantages of this approach are that a mass balance of the nitrogen in the soil can be calculated and that some of the isotopic fractionations can be determined. Cheng et $\underline{\text { l }}$. (1964) analyzed nine different nitrogenous species and found a wide isotopic variation, but did not calculate a mass balance nor identify any fractionations.

The analysis of $\delta N^{15}$ of nitrogen from different sources cannot be used to trace groundwater nitrate because the technique assumes that no isotopic fractionation occurs as the original nitrogen compound is chemically altered to the nitrate form in the groundwater. Kohl et al. (1971) compared the $\delta \mathrm{N}^{15}$ of a nitrogen fertilizer to the $\delta \mathrm{N}^{15}$ of $\mathrm{NO}_{3}$ in Decatur Reservoir in Illinois. They assumed that there was no isotopic fractionation as the nitrogen fertilizer was integrated into the soil nitrogen cycle and then leached as nitrate. This is one point on which Hauck et al. (1972), Hauck (1973), and Edwards (1973) severely criticized Kohl et al. (1971)。 
The approach I have taken is to identify the $\delta N^{15}$ of nitrate from different natural soil environments. This permits a direct comparison of the $\delta \mathrm{N}^{15}$ of nitrate in the soils to the $\delta N^{15}$ of the groundwater. The nitrate in a soil should be analyzed in samples collected from different depths to ascertain whether the $\delta N^{15}$ remains constant as the nitrate is leached through the soil profile. This approach also simplifies analytical techniques because only one nitrogen species is analyzed. This approach has two disadvantages: (1) it provides little quantitative information about the nitrogen cycle in a particular environment, and (2) a worker may not know the total history of a natural soil. The latter problem occurred in this study where a soil originally thought to be in its virgin prairie condition was later found to be contaminated with animal waste material.

Results and discussion of $\delta N^{15}$ of nitrate in different soil environments

The soil-nitrogen environments studied were barnyards, septic tank drain fields, cultivated fields where cattle had never grazed, cultivated fields where cattle had grazed, turnroads between cotton fields, and virgin prairie. Soil samples were collected in southern Runnels County, Texas, and in the feedlot of Capital Cattle Livestock Commission, Austin, Texas. Kreitler (1972) reported that all the soil environments listed above, with the exception of virgin prairie, 
could have high nitrate concentrations. The turnroads, narrow dirt roads between cultivated fields used to bring farm equipment to the fields and as turning areas for tractors, had abnormally high nitrate concentrations, but no obvious source of nitrogen. Soils in barnyard and septic tank drain fields had abnormally high nitrate concentrations with an obvious source. Soils treated with artificial fertilizers were not considered because there is little nitrogen fertilizer used in Runnels County. Fertilizers are used sparingly in dry land farming because of their potential to "burn" the crops with insufficient rainfall (Parker, C. T., Runnels County Agricultural Agent, personal communication, June 1970). Soil samples were collected from sites previously sampled by Kreitler (1972) because the approximate nitrate concentrations and probable source of nitrate was already known. Sampling sites were located in as wide a geographic area as possible and in many different soil associations so that the $\delta N^{15}$ ranges would represent the average for a large area. Hauck et al. (1972), Hauck (1973), Bremner and Tabatabai (1973), and Edwards (1973) criticized Kohl et al. (1971) for having only one datum point in establishing the $\delta N^{15}$ of "virgin" soil covering 900 square miles with 50 different soil series. This type of problem has, hopefully, been avoided in this study. Plate 1 shows the geographic distribution of soil samples and the different soil associations sampled. Appendix 
2 (p. 128) lists sample numbers, location, owner, depths of sampling, nitrate concentrations, and $\delta \mathrm{N}^{15}$ values. Soil sample locations are shown on Plate 2.

Nitrates in soils from barnyards and septic tank laterals.--Figure 6 compares $\delta N^{15}$ and nitrate concentrations of a barnyard soil at various depths. The value of $\delta N^{15}$, approximately $+14 \%$, remains relatively constant with depth. The nitrate concentrations are high, similar to nitrate profiles of barnyards shown by Kreitler (1972). The higher $\delta N^{15}$ at a depth of three feet, which appears to coincide with the nitrate peak at that depth, is not considered significant because the increase is only slightly greater than the experimental error.

Figure 7 shows the $6 N^{15}$ values and nitrate concentrations from five other barnyards. The location and depth of each sample is listed in Appendix 3 (p. 129) and on Plate 2. The five $\delta N^{15}$ values are consistent with the $\delta N^{15}$ values of Figure 6. Figure 7 also shows the $\delta N^{15}$ and nitrate concentrations of soils in septic tank drain fields. The $\delta \mathrm{N}^{15}$ values of these soils are greater than $+10 \%$.

The right side of Figure 8 is a frequency distribution curve of the $\delta \mathrm{N}^{15}$ values of nitrate from barnyard and septic tank drain field soils in southern Runnels County, Texas. Nitrates in soils from cultivated fields and turnroads with no history of cattle.--Figures $3(p, 27), 4(p, 28)$, 


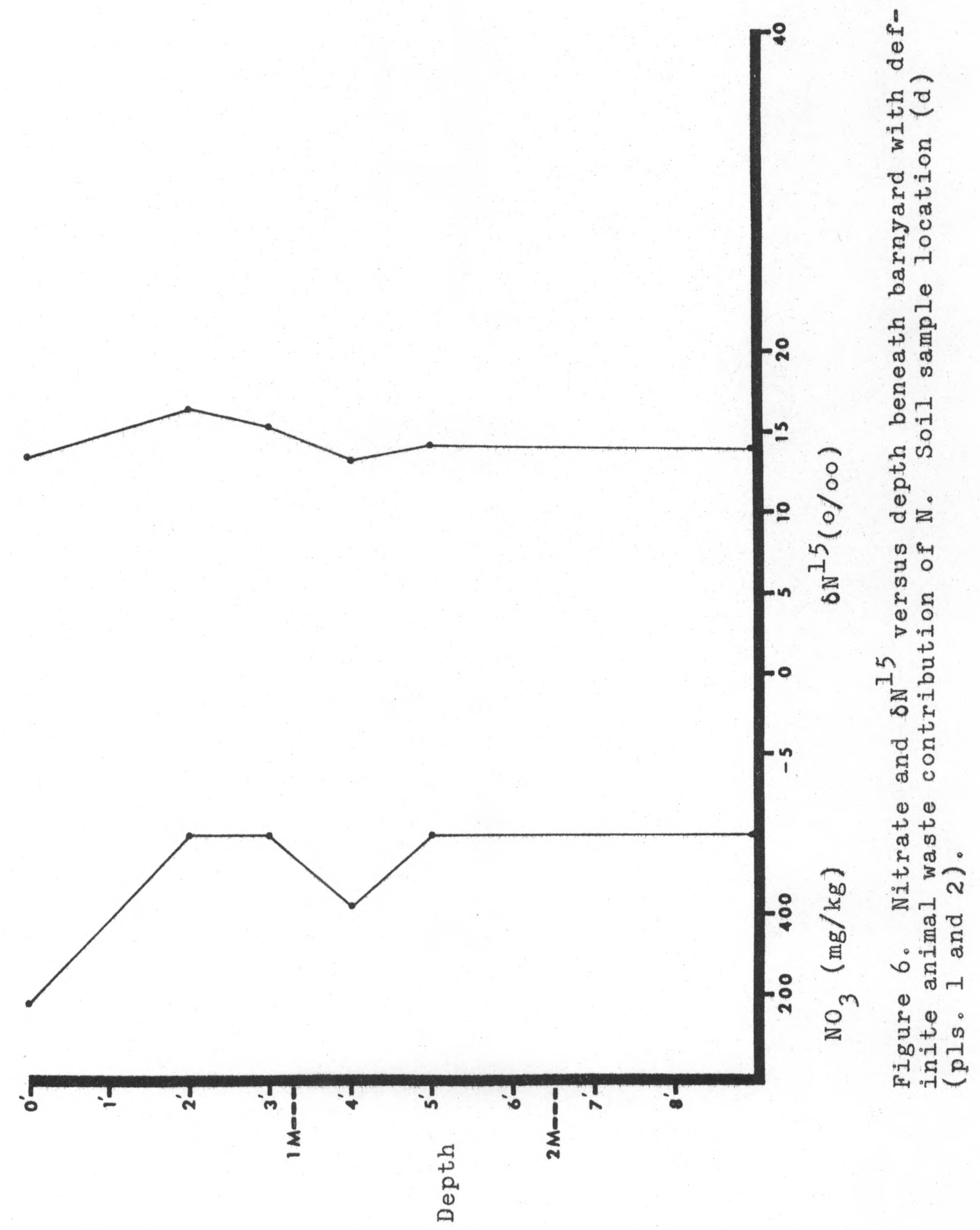




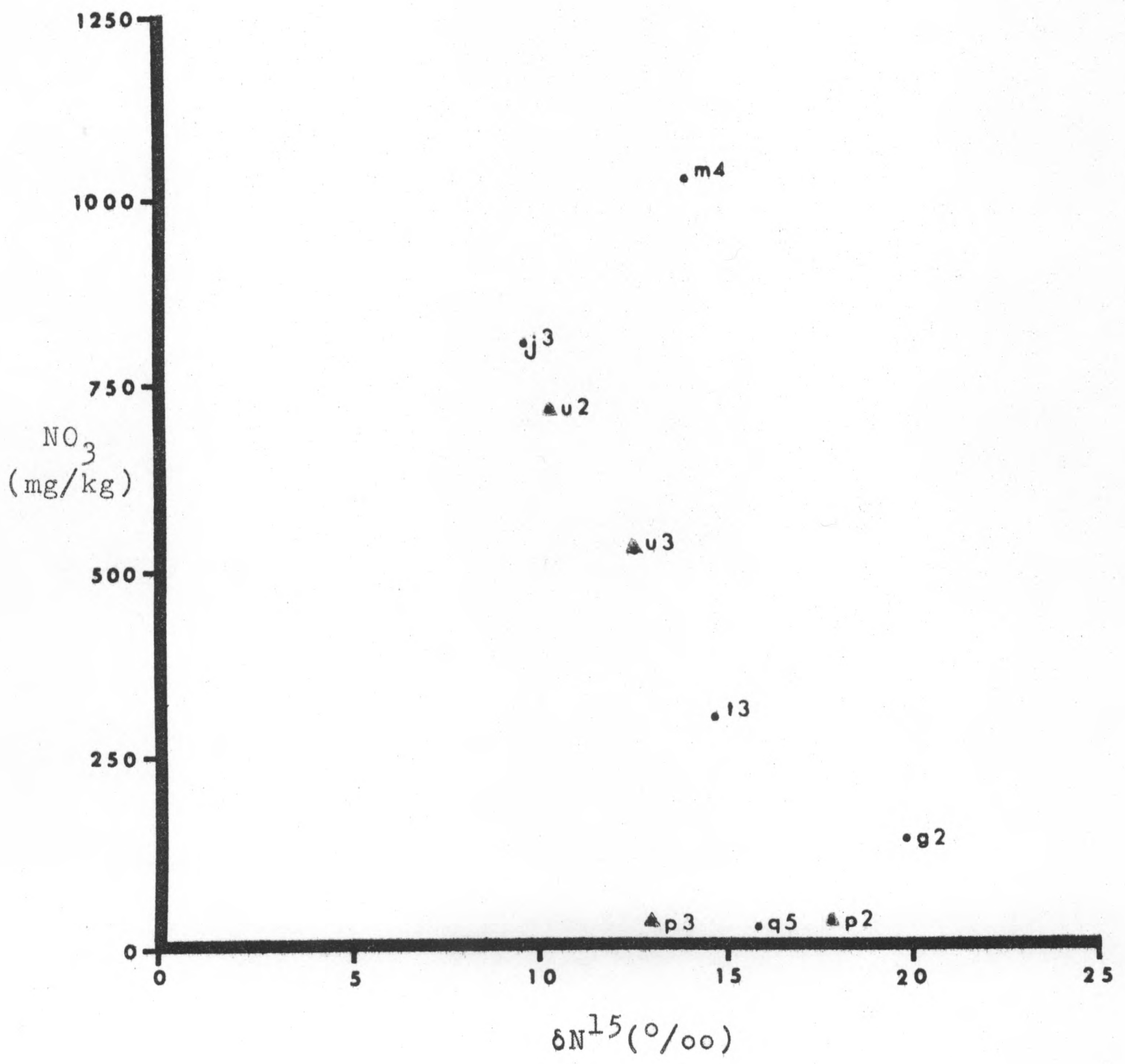

Figure 7. $\delta N^{15}$ and $\mathrm{NO}_{3}$ in soils from barnyards (-) and septic tank laterals (a). Detalled data are listed in Appendix 3 . 


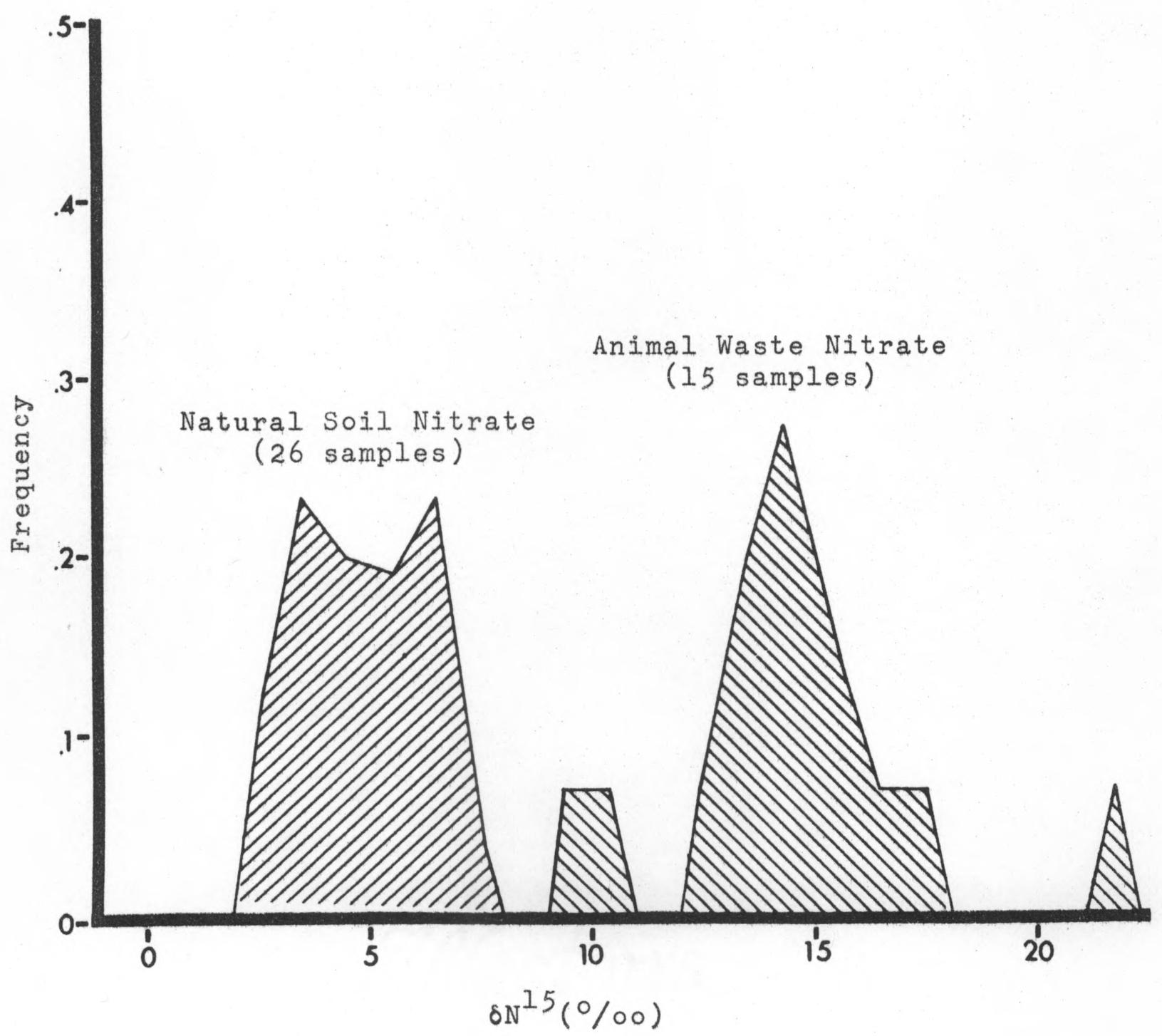

Figure 8. $6 \mathrm{~N}^{15}$ ranges of natural soil nitrate and animal waste nitrate (Runnels County, Texas). Frequency polygons have a class interval of one $\delta N^{15}$ unit. Cumulative frequency of each curve is equal to 1.0 . 
9, and 10 compare the $\delta \mathrm{N}^{15}$ and nitrate concentrations in soils from various depths in cotton fields where, according to the land owners, livestock have never grazed. These soils have low nitrate concentrations and lower $\delta N^{15}$ than the $\delta N^{15}$ of barnyard or septic tank nitrate. The $\delta N^{15}$ of Figures 3, 4, and 9 remain constant with depth, whereas Figure 10 shows a $5 \%$ variation. Some soil samples of Figure 10 were reanalyzed because of the coarse-grained Devardas Alloy used in the preparation of the sample and the slightly negative values obtained. There is no apparent correlation of $\delta N^{15}$ with nitrate concentration, soil type, or geographic distribution of cotton field soils.

Figures 11 and 12 show the $\delta N^{15}$ and nitrate concentration in soils from turnroads. Cattle have never grazed along these roads. These soils have similar $\delta N^{15}$ values, but higher nitrate concentrations in comparison to cultivated fields with no history of cattle. In both turnroad profiles, the $\delta \mathrm{N}^{15} \mathrm{re-}$ mains constant with depth even though the nitrate concentrations vary greatly. The soils represented in Figure 10 ( $p$. 42) and Figure $12(p .44)$ are within thirty feet of each other. The $\delta N^{15}$ 's in the lower parts of the profiles are similar. The difference in nitrate concentrations of these two soils reflects the complete lack of plant growth on the turnroads, in contrast to the nutrient assimilation by crops in the cultivated fields. In the planted fields some of the soil humus is 


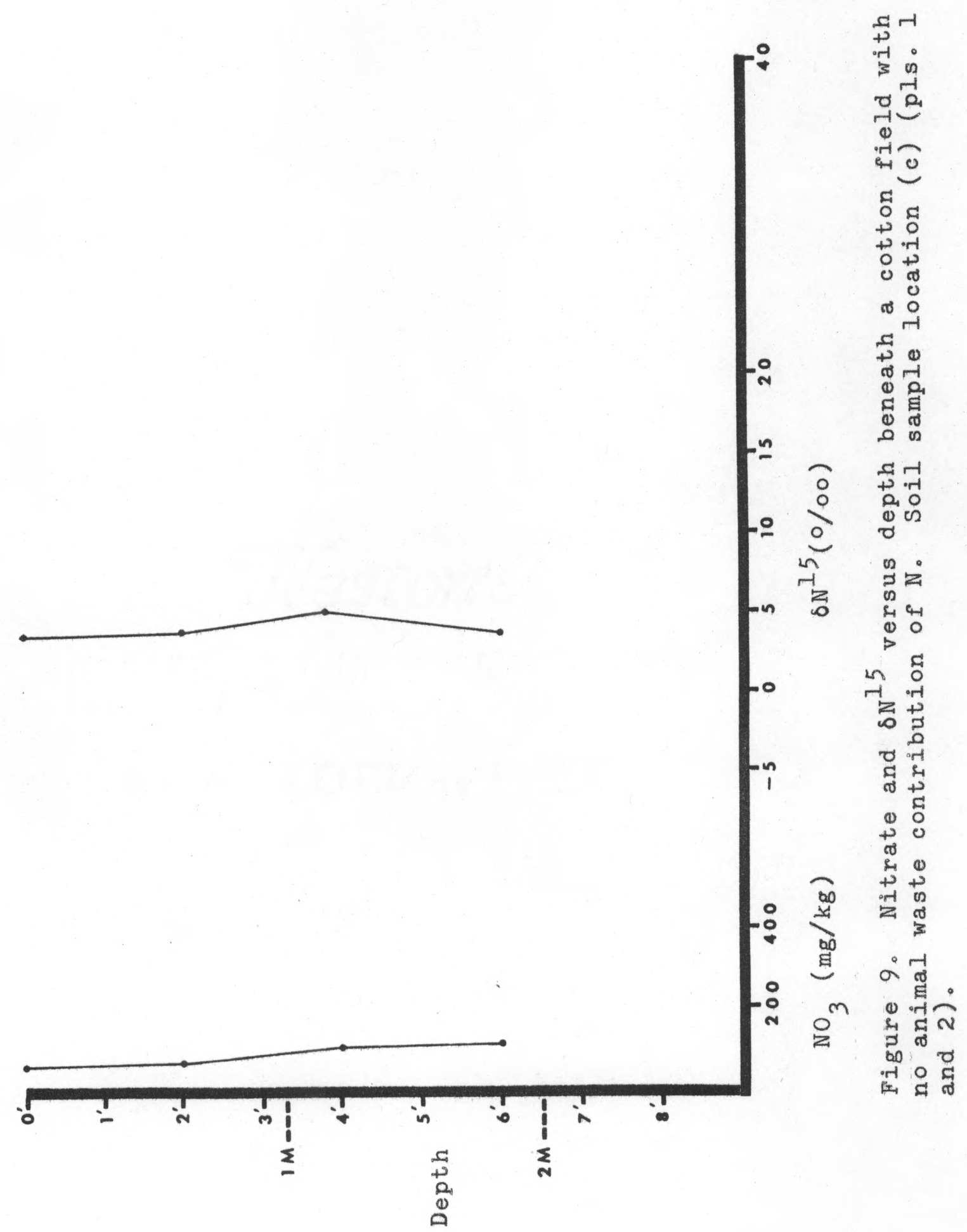




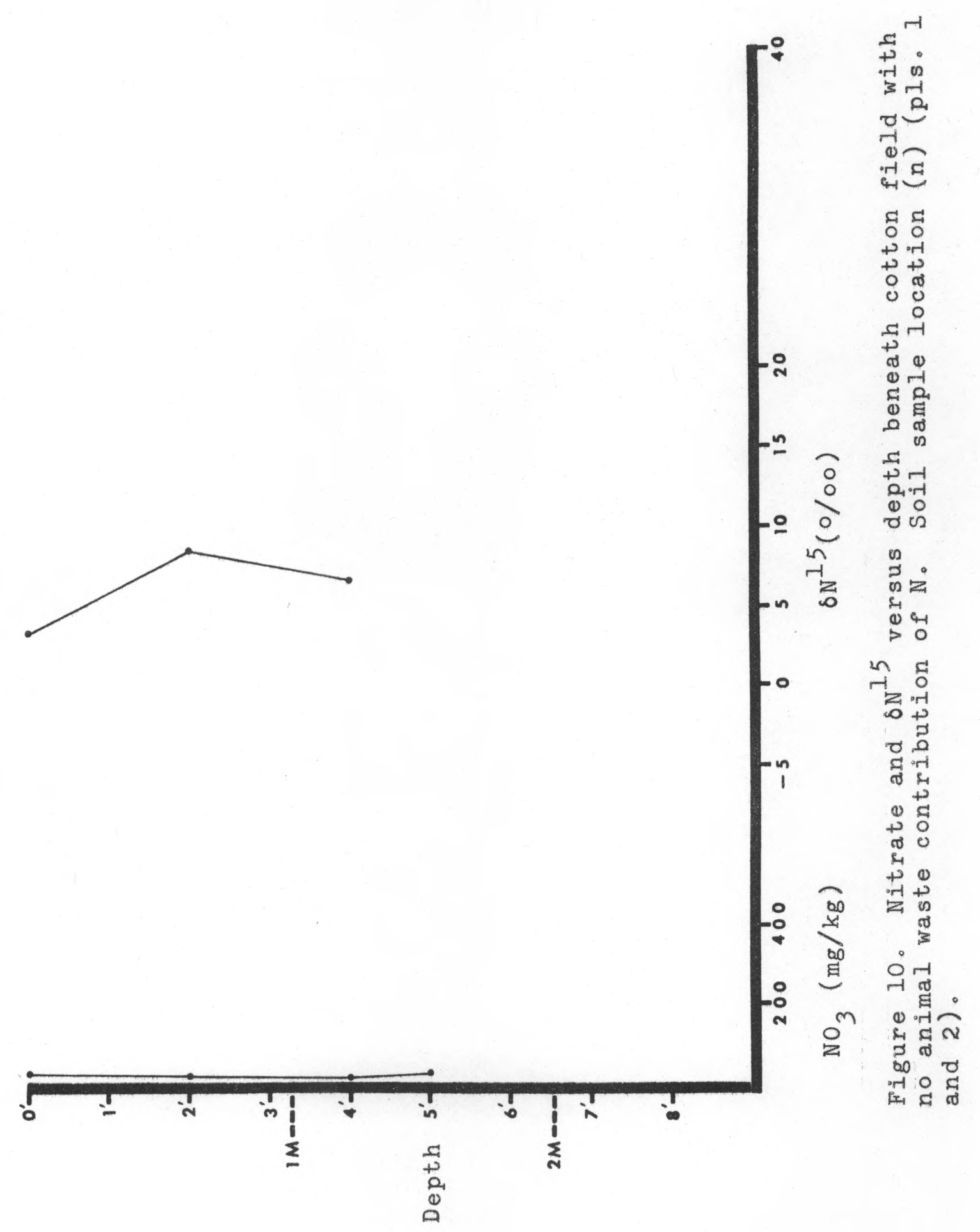




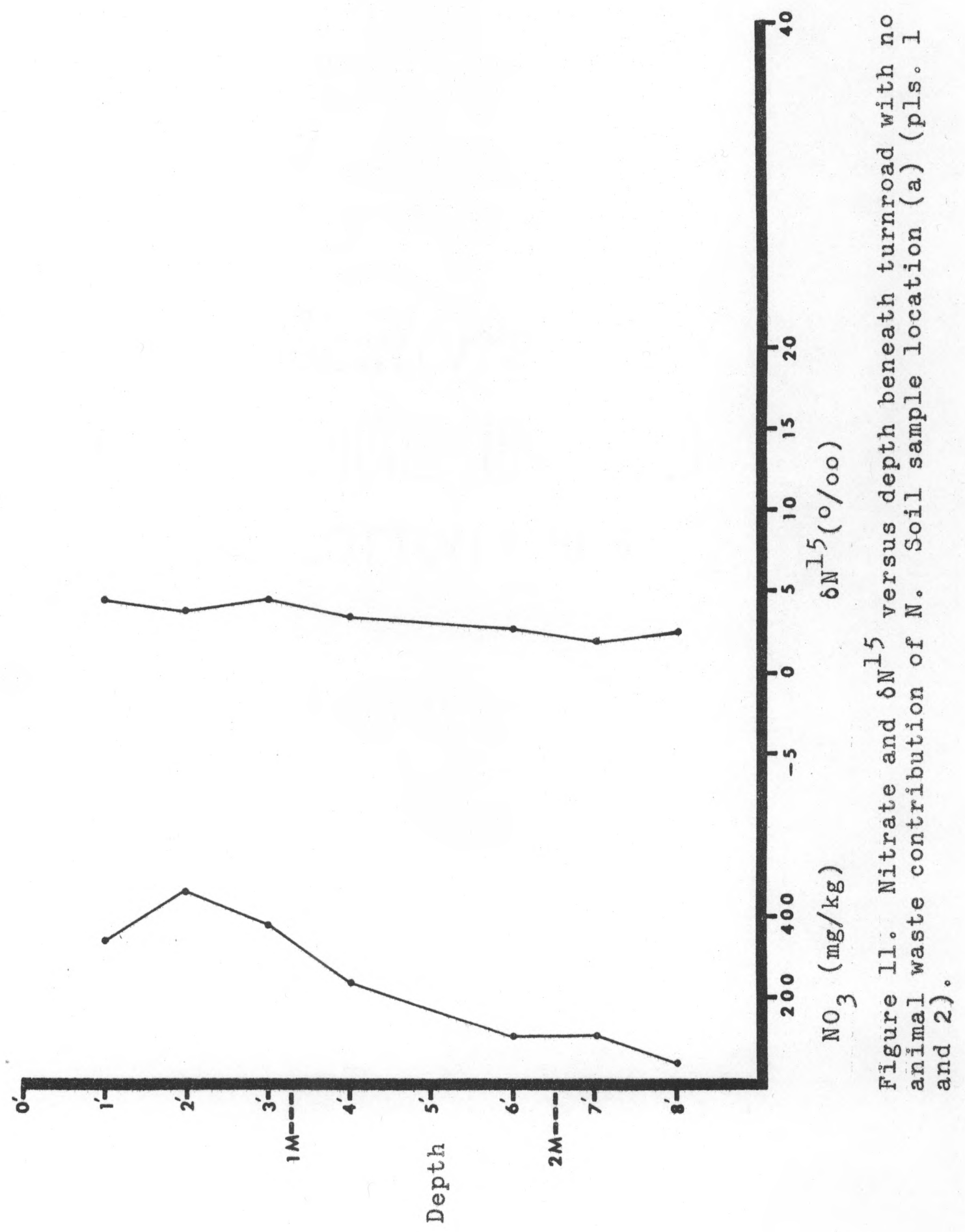




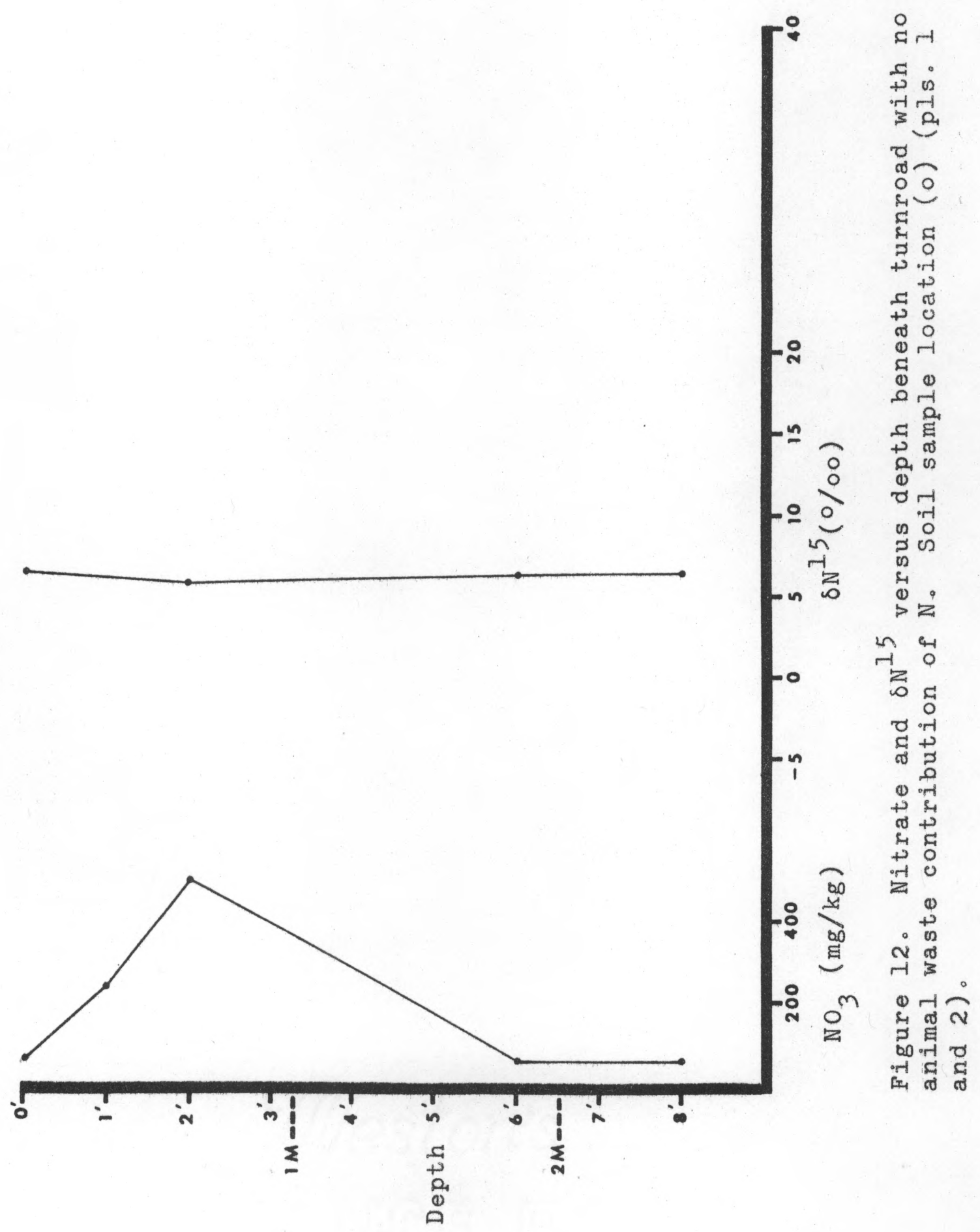


annually oxidized to nitrate which is assimilated as plant nutrient. In the turnroad soil there is no utilization of the nitrate by plants, thus nitrate concentrations are high. The left side of Figure $8(p .39)$ is the frequency distribution of $\delta \mathrm{N}^{15}$ in the cultivated fields with no history of cattle and the turnroads with no history of cattle. These environments produce a lower isotopic range than the barnyard and septic tank soils.

Nitrates in soils from corn fields with grazing cattle.-Figures 13 and 14 are $8 \mathrm{~N}^{15}-\mathrm{NO}_{3}$ profiles of corn fields where cattle have grazed on the corn stubble. The owners could not remember how long cattle had grazed in these fields, but they had a "feeling" that it was for the past ten to twenty years. Figure 14 has only two $\delta N^{15}$ data points because the rest of the soil nitrate samples were contaminated by a janitor cleaning the lab with an ammonia cleaning solution. Figure 13 shows lower $\delta N^{15}$ values with depth, but constant nitrate concentrations. The two $\delta N^{15}$ points on Figure 14 show the same trend. My interpretation of this profile is that the dominant source of nitrogen has changed with time. The nitrates deeper in the profile are older than the nitrates shallower in the profile. The $\delta N^{15}$ of nitrate from shallow depths is in the range of animal waste material, whereas the $\delta \mathrm{N}^{15}$ in the deeper portion of the profile is in the range of natural soil nitrogen. The higher values represent nitrate 


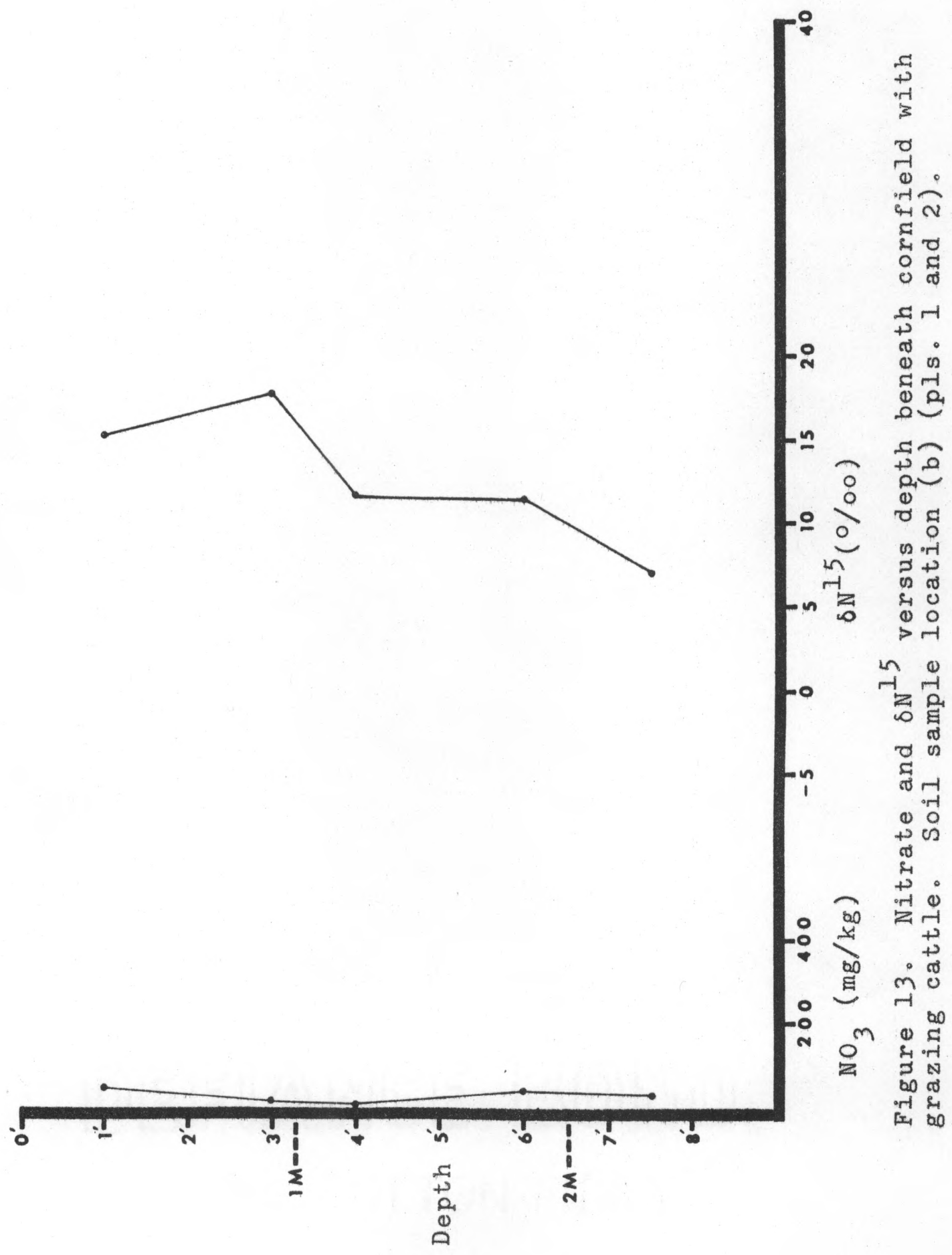




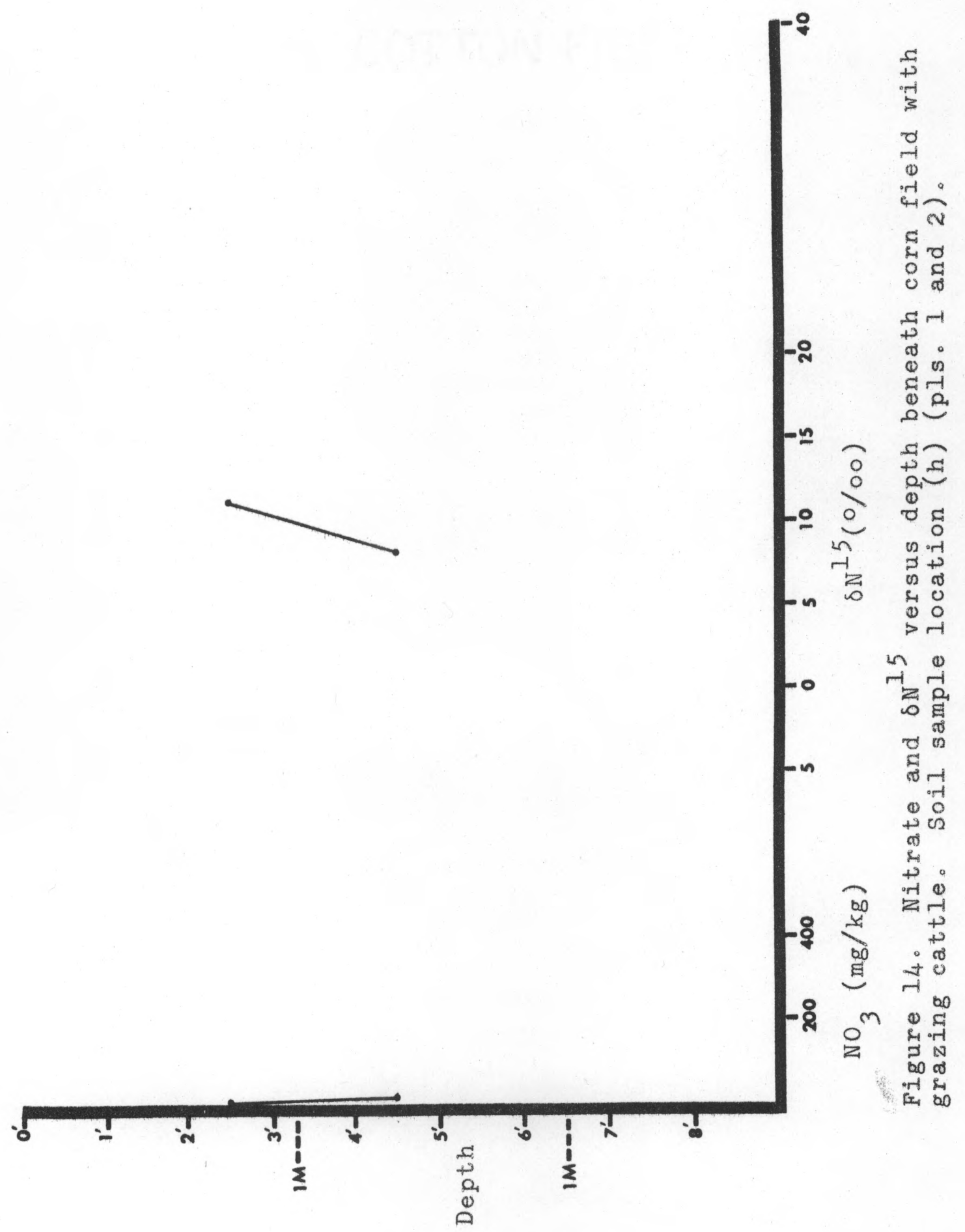


accumulation during the years when cattle grazed on the corn stubble, whereas the lower $\delta N^{15}$ values represent nitrate accumulation during the years before the cattle were grazing this field.

\section{Nitrates in soils from prairies.-Figure 15 repre-} sents the $\delta \mathrm{N}^{15}$, nitrate, and chloride profiles of a soil considered to be in "virgin" prairie state. The sampling site was $0.5 \mathrm{~km}$ north of Rowena, Texas, along the right-of-way of the Santa Fe Railroad which was built in the late $1800^{\prime} \mathrm{s}$. The sampling site has been maintained as a right-of-way since that time, and, according to the local farmers, has never been grazed. Another sample was collected from a soil in virgin prairie state along the Santa Fe right-of-way, but a few kilometers further north of Rowena, Texas.

I do not believe that the high $\delta N^{15}$ values found in the soil in Figure 15 portray accurately the isotopic range of a virgin prairie soil. The ground apparently has been contaminated by animal wastes falling from the livestock box cars as the trains accelerated out of the Rowena, Texas, station. My reasoning for this hypothesis is that the $\delta N^{15}$ values occupy the upper range of animal waste material. Only one other sample had a higher $\delta N^{15}$ value, and that was nitrate from pig urine with a value of $+46 \%$. The anomalous nitrate concentrations of the prairie soil are higher than the nitrates found in pasture soils (Kreitler, 1972) and are much higher 


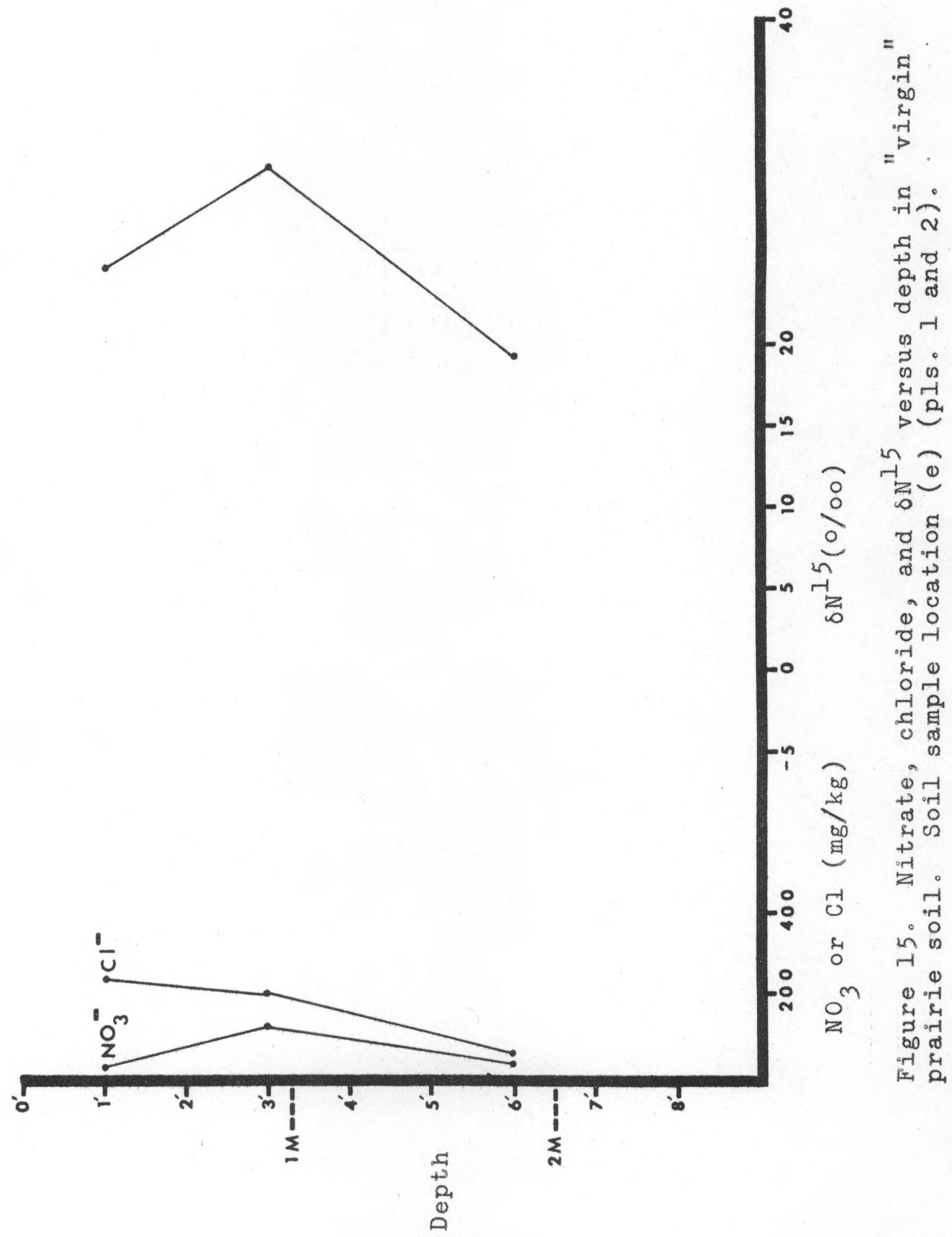


than the second virgin prairie soil that I sampled. The nitrate levels in this second prairie soil were too low for isotopic analysis. The chloride concentrations, measured with an Orion Specific Ion electrode for $\mathrm{Cl}^{-}$, were much higher than had been found in pastures or in cultivated fields. Kreitler (1972) reported high chloride concentrations in soils contaminated by animal wastes and nonmeasurable to barely measurable chloride concentrations in soils with no animal waste. These lines of evidence suggest that the assumed virgin prairie soil was a poor choice.

The soils which have a known source of nitrate can be divided into two categories: (1) soils with animal waste material as a dominant nitrate source, and (2) soils with a natural soil nitrate source with no contribution from animal waste material (fig. 8, p. 39). These isotopic ranges do not overlap. Soils from fields with grazing cattle would be expected to have $\delta N^{15}$ values between the $\delta N^{15}$ of nitrate of animal wastes and the $\delta \mathrm{N}^{15}$ of natural soil nitrate, reflecting a mixing of nitrates from the two sources. 
ISOTOPIC FRACTIONATION CONTROLLING $\delta N^{15}$ OF NITRATE IN SOUTERN RUNNELS COUNTY, TEXAS

\section{Isotopic fractionation and its role}

\section{in natural systems}

The isotopic ratio of a nitrogen compound is the result of (1) physical fractionation, (2) chemical equilibrium fractionation, (3) chemical kinetic fractionation, and (4) the isotopic ratio of the source material.

Physical fractionations occur through diffusion, evaporation and sublimation (Ingerson, 1953). In diffusion the Iighter isotope will have a higher velocity. In evaporation and sublimation the lighter isotope will have a higher vapor pressure (Bigeleisen, 1965), which favors the loss of the lighter isotope.

Chemical equilibrium fractionation (isotope exchange equilibrium) is the concentration of an isotope in one species of a chemical equilibrium reaction. The values of the isotope equilibrium constants are dependent on the different energy levels of the molecules (Urey and Greiff, 1935). The isotopic equilibrium constants $(K \text { or } \alpha)^{l}$ have been determined experimentally and/or calculated from partition functions relevant to surface or near surface conditions (Table 7).

\section{where:}

IThe calculated isotope equilibrium constant is " $\mathrm{K}$ ",

$$
K=\frac{(\text { Products })}{\text { (Reactants }} \text {. }
$$




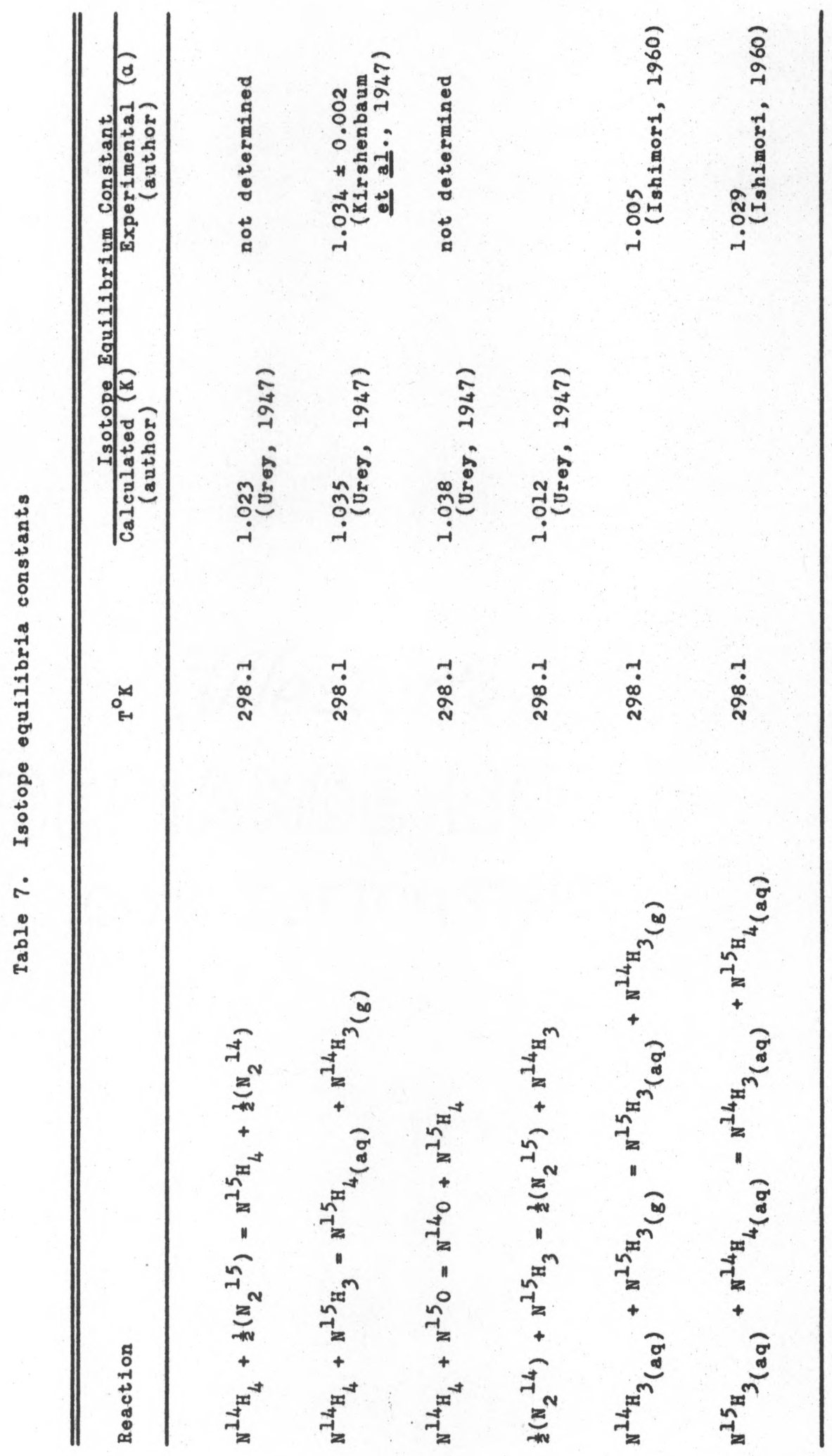


Chemical kinetic fractionations occur in nonequilibrium reactions which are typical of biogeochemical systems. When a reaction does not go to completion, the lighter isotope is often concentrated in the products while the heavier isotope is concentrated in the reactants.

Physical fractionation, chemical equilibrium fractionation, and chemical kinetic fractionation are all important in the isotopic fractionation of nitrogen in natural biogeochemical systems. However, their relative importance is only

The second reaction of Table 7 is written:

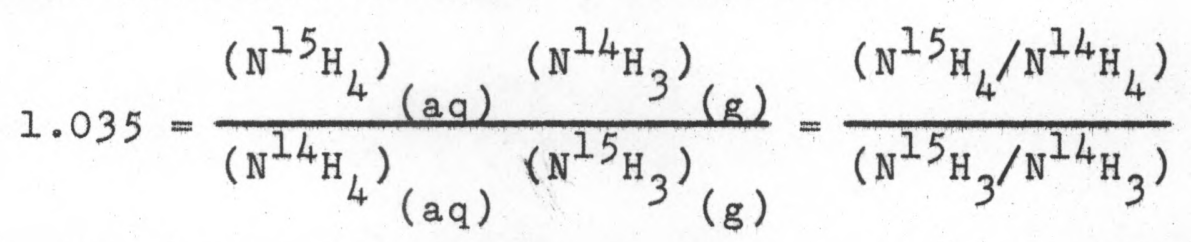

The experimentally determined isotope equilibrium constant is " $\alpha$ ", where:

$$
\alpha=k^{1 / n}
$$

$n$ is the number of equivalent exchangeable atoms in the reaction. In equations 1 through 6 (table 7 ), there is only one exchange atom, thus:

$$
\alpha=K
$$

For reaction 2 ,

$$
\alpha=1.034=\frac{\mathrm{N}^{15} / \mathrm{N}^{14}\left(\mathrm{NH}_{4}\right) \text { reactant }}{\mathrm{N}^{15} / \mathrm{N}^{14}\left(\mathrm{NH}_{3}\right)_{\text {reactant }}}
$$

This equation states that there is a $340 \%$ enrichment of $\mathrm{N}^{15}$ in $\mathrm{NH}_{4}$ compared to $\mathrm{NH}_{3}$. Further usage of the term $\alpha$ in this study is based on these conventions. 
beginning to be ascertained.

\section{Nitrogen isotope fractionations}

related to soils

The original nitrogen source for a soil system is atmospheric nitrogen. As the nitrogen moves through the soil, it can be fractionated by a variety of chemical reactions causing the intermediate nitrogen compounds to have different isotopic compositions. The $\delta \mathrm{N}^{15}$ of soil nitrate may also be influenced by fractionations in animal and plant protein as well as soil reactions.

Nitrogen fixation.--Nitrogen fixation is the process in which organisms break the $\mathrm{N}_{2}$ triple bond of elemental nitrogen gas and reduce it to ammonia. This requires an organic carbon source, pyruvic acid, for energy to break the $\mathrm{N}_{2}$ bond and to donate electrons to the nitrogen atoms during reduction (Martin and Goff, 1972). In the soil ecosystems, symbiotic nitrogen fixation and nonsymbiotic fixation both occur.

Nonsymbiotic nitrogen fixation is accomplished by a limited number of bacteria genera, e.g., Azotobacter and Clostridium. Hoering and Ford (1960) observed a kinetic fractionation $(B)^{1}$ of 1.0022

${ }^{I_{B}}$ is the kinetic fractionation factor for nonequilibrium reactions. No single convention for its usage has been established. Because of this, the equation defining $B$ will be given for each kinetic fractionation discussed. 


$$
B=\frac{N^{15} / N^{14}\left(\text { atmospheric } N_{2}\right)}{N^{15} / N^{14}(\text { fixed nitrogen })}
$$

for nitrogen fixation with Azotobacter vinelandii. They considered this $B$ factor small enough to mean no fractionation at all. With the same bacteria, Delwiche and Steyn (1970) measured a kinetic fractionation of 1.004

$$
B=\frac{N^{15} / N^{14}\left(\text { atmospheric } N_{2}\right)}{N^{15} / N^{14}(\text { fixed nitrogen })}
$$

indicating a slight preference of $\mathrm{N}^{14}$ in the fixed nitrogen during nitrogen fixation.

Symbiotic nitrogen fixation is characterized by rhizobium bacteria associated with leguminous plants. No isotope studies have been made of this type of fixation.

Nitrification.--Nitrification is the oxidation of ammonium to nitrate. The reaction is a two-step biological process. Nitrosomonas bacteria convert ammonium to nitrite; Nitrobacter bacteria then convert nitrite to nitrate. Delwiche and Steyn (1970) measured a kinetic fractionation of 1.026

$$
B=\frac{N^{15} / N^{14}\left(\mathrm{NH}_{3}\right)}{N^{15} / N^{14}\left(\mathrm{NO}_{2}\right)}
$$


for the oxidation of ammonium to nitrite with Nitrosomonas europeae. Myaka and Wada (1971) observed the depletion of $\mathrm{N}^{15}$ in nitrite during the oxidation of ammonium to nitrite with marine nitrifying bacteria. Studies of the second half of the nitrifying reaction have not been made because of the difficulty of analysis.

Denitrification.--Denitrification is a biochemical reduction of nitrate and nitrite to nitrogen gas or nitrous oxide. Nitrite and nitrate are hydrogen acceptors in this anaerobic reduction (Martin and Goff, 1972). Wellman, Cook, and Krouse (1968) measured a kinetic fractionation of approximately 1.02

$$
B=\frac{N^{15} / N^{14}\left(\mathrm{NO}_{3}\right)}{N^{15} / \mathrm{N}^{14}\left(\mathrm{~N}_{2}\right)}
$$

for denitrification with Pseudomonas denitrificans. Delwiche and Steyn (1970), using the same species, measured a kinetic fractionation of 1.0173 .

$$
\text { Myaka and Wada (1971), using a marine denitrifying }
$$
bacteria, measured a kinetic fractionation of approximately 1.02

$$
B=\frac{N^{15} / N^{14}\left(\mathrm{NO}_{3}\right)}{N^{15} / N^{14}\left(\mathrm{~N}_{2}\right)}
$$


The nitrogen gas produced during denitrification is depleted in $\mathrm{N}^{15}$.

Ion exchange.--Cation exchange resins (Dowex 50) and kaolinitic clay prefer $\mathrm{N}^{15} \mathrm{H}_{4}$ to $\mathrm{N}^{14} \mathrm{H}_{4}$; and $\mathrm{B}=0.99926$

$$
B=\frac{N^{15} / N^{14}\left(\text { solution } \mathrm{NH}_{4}\right)}{N^{15} / N^{14}\left(\text { adsorbed } \mathrm{NH}_{4}\right)}
$$

for cation exchange; and $B=0.99922$

$$
B=\frac{\left.N^{15} / N^{14} \text { (solution } \mathrm{NH}_{4}\right)}{N^{15} / \mathrm{N}^{14}\left(\text { adsorbed } \mathrm{NH}_{4}\right)}
$$

for kaolinite.

Anion exchange resins (Dowex 1) prefer isotopically light nitrate; and $B=1.0021$

$$
B=\frac{N^{15} / N^{14}\left(\text { solution } \mathrm{NO}_{3}\right)}{N^{15} / N^{14}\left(\text { adsorbed } \mathrm{NO}_{3}\right)}
$$

(Delwiche and Steyn, 1970). None of these reactions shows fractionations as large as nitrification (1.02), denitrification ( 1.02$)$, or ammonia volatilization ( 1.034$)$, and are probably not important in the soil nitrogen system. Ammonia volatilization.--Ammonia is the end product of two biological reactions in soil: nitrogen fixation and 
ammonification of organic nitrogen. Most soils are neutral or acidic, and the ammonia goes rapidly to ammonium $\left(\mathrm{NH}_{3}+\right.$ $\left.\mathrm{H}<>\mathrm{NH}_{4} ; \mathrm{K}=9.34\right)$. However, if any gaseous ammonia is lost from the system, an equilibrium isotope fractionation can occur with an a factor of 1.034:

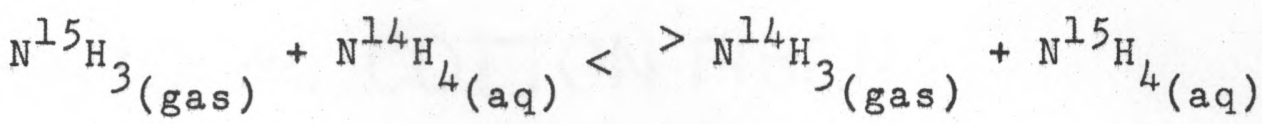

$$
\begin{aligned}
& \alpha=1.034=\frac{\left(N^{15} / \mathrm{N}^{14}\right) \mathrm{NH}_{4}(\mathrm{ag})}{\left(\mathrm{N}^{15} / \mathrm{N}^{14}\right) \mathrm{NH}_{3}(\mathrm{~g})}
\end{aligned}
$$

The result will be a loss of isotopically light ammonia gas. Nutrient assimilation.--Plants and some animals, such as a few bacteria, Eumycetes, and flagellates, assimilate most nitrogen as ammonium and nitrate. A few plants have the ability to absorb organic nitrogen. Delwiche and Steyn (1970)

showed that bacteria preferentially use $\mathrm{N}^{14} \mathrm{H}_{4}$ over $\mathrm{N}^{15} \mathrm{H}_{4}$. Studies of the residual nitrogen after plant nutrient assimilation have not been made. Commoner (1970a) studied the fractionation of nitrogen isotope tracers within vascular plants but there was total assimilation of the nitrogen tracer, hence no residual could be analyzed.

\section{Fractionations within more complex plants and ani-}

mals.--Nitrogen passes through plants and animals, thus important isotopic fractionations may occur in vivo. Gaebler et 
al. (1966) observed an enrichment of $\mathrm{N}^{15}$ in amino acids from rat liver protein and rat muscle protein, relative to the isotopic composition of the ingested amino acids (table 8 ). These variations were not caused by experimental error (Gaebler et al., 1963). The nonessential amino acids, those that animals are capable of generating, were more enriched in $\mathrm{N}^{15}$ than the essential amino acids, those that animals cannot generate. The fractionation is attributed to nitrogen transfer in the protein.

Myaka and Wada (1967) observed a gradual enrichment of $\mathrm{N}^{15}$ with higher trophic levels of marine organisms. The average $\delta \mathrm{N}^{15}$ of total nitrogen of phyloplankton and seaweed was $+70 / 00$, whereas the average $\delta N^{15}$ of zooplankton and fish was $+10 \%$ and $+15 \%$, respectively. As the organisms of higher trophic levels ingest the organisms of lower levels, the protein of the higher levels of the food chain become enriched in $N^{15}$. This suggests a fractionation similar to the $\mathrm{N}^{15}$ enrichment in protein observed by Gaebler et al. (1966). Commoner (1970a) found that in tobacco leaves, the alcohol-precipitable nitrogen in proteins and nucleic acids was isotopically lighter than the alcohol-soluble nitrogen in low molecular weight compounds such as amino acids, ammonia, and nitrate. Isotopic fractionations do occur within plants and animals. Their influence on the isotopic composition in the soil nitrogen system is not known. 
Table 8. Accumulation of $\delta N^{15}$ in proteins of rats (from Gaebler et al., 1966)

$\delta \mathrm{N}^{15}$ in rat protein minus $\delta \mathrm{N}^{15}$

in dietary protein $(0 / 00)$

\begin{tabular}{|c|c|c|c|c|}
\hline Source of Nitrogen & Protasoy ${ }^{1}$ & Group & Caesin ${ }^{1}$ & Group \\
\hline Nonessential Amino Acids & Liver & Muscle & Liver & Muscle \\
\hline Proline & +8.8 & $+4 \cdot 1$ & $+8 \cdot 5$ & $+3 \cdot 5$ \\
\hline Glutamic Acid & $+7 \cdot 7$ & +6.8 & $+4 \cdot 6$ & $+3 \cdot 3$ \\
\hline Alanine & $+3 \cdot 5$ & $+5 \cdot 7$ & $+4 \cdot 1$ & +4.8 \\
\hline Aspartic Acid & $+3 \cdot 0$ & $+3 \cdot 6$ & +3.8 & $+4 \cdot 4$ \\
\hline Arginine & $+7 \cdot 4$ & +3.6 & $+7 \cdot 1$ & +3.0 \\
\hline Glycine & $+3 \cdot 8$ & $+7 \cdot 7$ & +5.8 & +6.0 \\
\hline Serine & $+9 \cdot 3$ & $+7 \cdot 1$ & $+5 \cdot 2$ & $+2 \cdot 5$ \\
\hline Tyrosine & +1.6 & $-0 \cdot 3$ & +1.6 & -0.1 \\
\hline \multicolumn{5}{|l|}{ Essential Amino Acids } \\
\hline Phenylalanine & -1.6 & -0.8 & +1.9 & 0.0 \\
\hline Ualine & +2.7 & +5.8 & +2.7 & $+5 \cdot 2$ \\
\hline Leucine & $+1 \cdot 3$ & $+6 \cdot 3$ & +3.8 & $+4 \cdot 1$ \\
\hline Lysine & +0.1 & 0.0 & $+2 \cdot 5$ & $-1 \cdot 1$ \\
\hline Histidine & +3.0 & +2.5 & $+4 \cdot 1$ & $+2 \cdot 2$ \\
\hline Threodine & $-2 \cdot 7$ & $-7 \cdot 4$ & $-3 \cdot 3$ & $-4 \cdot 4$ \\
\hline Amide Groups & $+4 \cdot 6$ & $+1 \cdot 1$ & 0.0 & 0.0 \\
\hline Amidine Groups & +8.8 & $+4 \cdot 1$ & +3.0 & -0.1 \\
\hline
\end{tabular}

1 - Dietary proteins 
Mineralization.--Decomposition or mineralization of organic nitrogen is the result of soil humus oxidizing to nitrate. The complex process involves deamination of proteins to amino acids, ammonification of amino acids to ammoniaammonium, and nitrification of ammonium to nitrate. Laboratory incubation of soils to produce nitrate is supposedly a simulation of field conditions. Cheng et al. (1964) found that after a two week incubation, the $\delta \mathrm{N}^{15}$ of the nitrate was $1 / 2$ to $1 / 3$ more negative than the $\delta N^{15}$ of the original total nitrogen. After twenty-two weeks of incubation, Bremner and Tabatabai (1973) found that $1 / 2$ of the samples had negative $\delta N^{15}$ values, while the other $1 / 2$ were slightly positive. Edwards (1973) incubated replicate samples of soils for two weeks and found that $\delta \mathrm{N}^{15}$ of the nitrate to be $+4.9 \%$, whereas the $\delta \mathrm{N}^{15}$ for the original total nitrogen was +11.7 $\%$. The results of these studies indicate that mineralization favors $\mathrm{N}^{14}$. However, two other studies complicate the interpretation. Myaka and Wada (1971) measured the $\delta N^{15}$ of the residual total nitrogen during the decomposition of Scenendesmus, a marine organism. In the first twenty days, the residual material became isotopically lighter, and then became slightly heavier for the duration of the experiment (120 days). In a forty-two week incubation study, Feigin and Shearer (1973) found that the $\delta N^{15}$ of the nitrate started low but eventually rose to the same value as the total nitrogen. 
They also found that the $\delta \mathrm{N}^{15}$ of the nitrate from nonincubated soil samples was significantly lighter than the $\delta N^{15}$ values for the nitrate found during incubation. Table 9 lists the available isotopic data on incubation of soils.

\section{Discussion of isotopic fractionations}

in southern Runnels County, Texas

The isotopic ranges of the two soil nitrate environments observed in Runnels County, Texas, are controlled by the isotopic fractionations described in the previous pages. A detailed discussion of the important fractionations will describe which chemical reactions control the isotopic ranges.

Soils contaminated with animal wastes.--The predominant source of the nitrate in soils contaminated with animal waste material is urea from urine. Approximately $80 \%$ of excreted nitrogen is in urine (spedding, 1971). Fifty to $85 \%$ of the urine is in the form of urea (table 10).

Urea is hydrolized to ammonia and carbon dioxide and then nitrified to nitrate:

$$
\begin{aligned}
& \mathrm{CO}\left(\mathrm{NH}_{2}\right)_{2(\mathrm{~g})}+\mathrm{H}_{2} \mathrm{O}(\mathrm{g}) \\
& \Delta \mathrm{G}^{\circ}=(-) 290 \mathrm{cal} \text { at } 25^{\circ} \mathrm{C} .
\end{aligned}
$$

The Gibbs free energy $\left(\Delta G^{\circ}\right)$ indicates that reaction will occur spontaneously, but experimentation indicates that the kinetics are very slow. The biochemical hydrolysis is much 


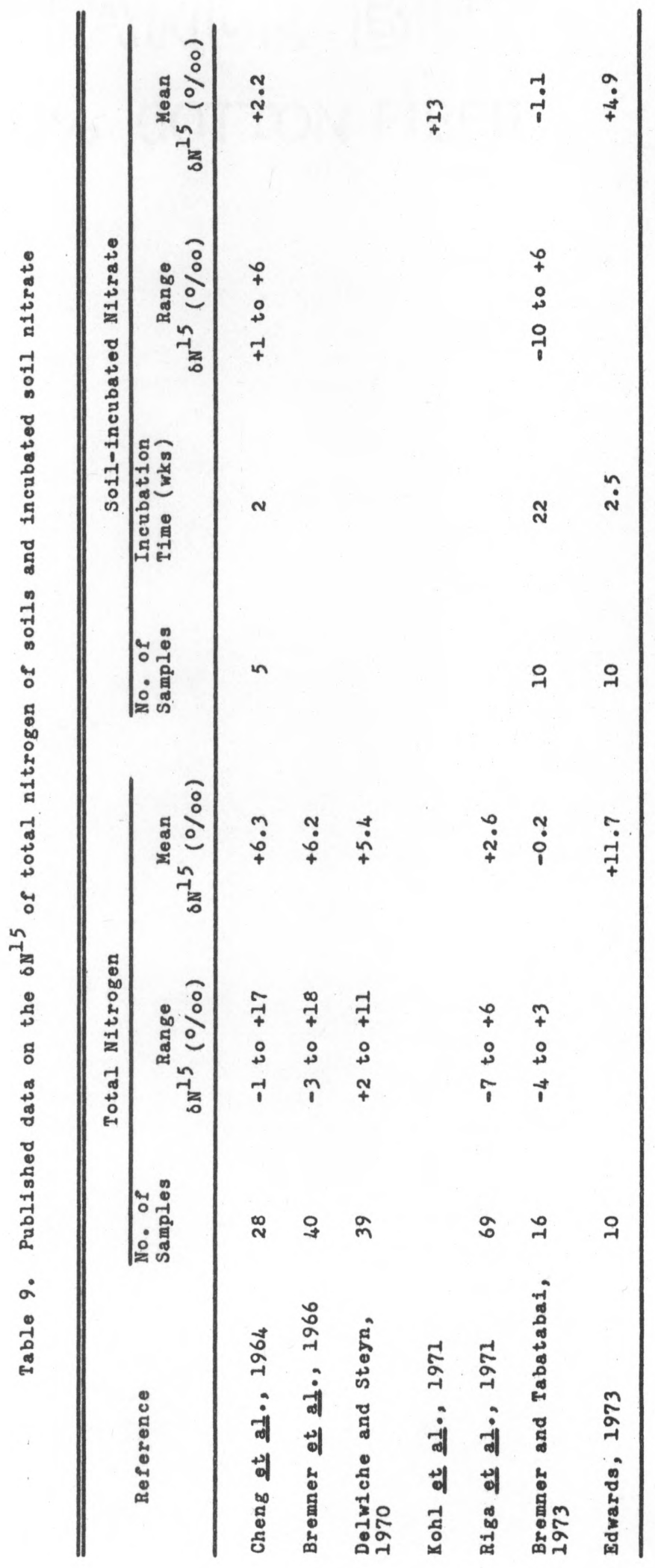


Table 10. Nitrogen compounds in bovine urine (from Doak, 1952).

Nitrogen Compound

Percent of Total Nitrogen in Urine (\%)

$\begin{array}{lccc} & \text { Calf (l year old) } & \text { Cow } \\ & \text { avg } & \underline{\text { range }} & \text { range } \\ \text { Urea - N } & 76.4 & 68-85 & 50.3-74.2 \\ \text { Allanine - N } & 4.1 & 2.9-5.2 & 4.0-6.4 \\ \text { Hippuric acid - N } & 2.6 & 2.1-3.1 & 1.9-6.0 \\ \text { Creatine - N } & 1.5 & 1.0-1.8 & 1.3-2.0 \\ \text { Amino - N } & 12.0 & 10.5-18.9 & \\ \text { Ammonia - N } & 0.7 & 0.5-0.9 & \end{array}$

Percent Total Nitrogen in Urine (\%)

Calf ( 1 year old) Cow

avg range range

Total - N

$8.68 \quad 5.7-12.0$

$2.5-8.3$ 
more rapid and is the normal reaction (Chin and Kroontze, 1963).

The hydrolysis of urea forms a weak acid $\left(\mathrm{CO}_{2}\right)$ and a strong base $\left(\mathrm{NH}_{2}\right)$. For every mole of carbonic acid formed, four moles of ammonium ion are created. This tremendous drain of $\mathrm{H}^{+}$ions causes the $\mathrm{pH}$ to rise and ammonia volatilization to occur. Doak (1952) measured pH changes during hydrolysis from an initial 5.5 to a maximum of 9.2. Stewart (1970) and Watkins et al. (1972) also observed pH rises during urea hydrolysis. The ammonia-ammonium reaction has a $\mathrm{K}$ equilibrium of 9.34 ; that is, at a $\mathrm{pH}$ of 9.34 there will be an equal molar concentration of ammonia and ammonium. A rise in $\mathrm{pH}$ will thus cause a conversion of ammonium to ammonia, and subsequent volatilization. Ammonia losses from the hydrolysis of urea also occur at pH's below 9.34. Ernst and Massey (1960) found 10\% ammonia loss from an urea fertilizer at a $\mathrm{pH}$ of 5.0 and $50 \%$ ammonia loss of the same fertilizer at a $\mathrm{pH}$ of 7.5. A pos- sible explanation for these phenomena is that the hydrolysis of urea creates micro-environments of high $\mathrm{pH}$. Ammonia volatilization from soils is affected by temperature, air speed, and soil moisture content as well as by the $\mathrm{pH}$. Higher temperatures cause greater ammonia losses (Volk, 1959; Watkins et al., 1972). Ammonia loss is directly proportional to air speed (Watkins et al., 1972). Soil moisture appears to be important in controlling ammonia losses. 
In one experiment, $90 \%$ of urea applied to dry soils was lost through ammonia volatilization, whereas only $25 \%$ of the urea applied to wet soils was lost through ammonia volatilization (Stewart, 1970). Quantifying the amount of ammonia lost during urea hydrolysis is not practical because of the number of variables involved, but there is no doubt that such loss does occur.

Ammonia volatilization appears to be a reaction controlling the isotopic composition of nitrate from animal waste material. The equilibrium isotope reaction

$$
\mathrm{N}^{15} \mathrm{H}_{3}(\mathrm{~g})+\mathrm{N}^{14} \mathrm{H}_{4}(\mathrm{aq}) \leftrightarrow \mathrm{N}^{14} \mathrm{H}_{3}(\mathrm{~g})+\mathrm{N}^{15} \mathrm{H}_{4} \text { (aq) }
$$

has an a factor of 1.034; that is, gaseous ammonia should be $+35 \%$ lighter than aqueous ammonium. The hydrolysis of urea in a barnyard soil should result in the loss of isotopically light ammonia gas. The nitrification of isotopically heavy ammonium will then form an isotopically heavy nitrate.

To check this hypothesis, I collected and analyzed three gaseous ammonia samples from urine-soaked soils in barnyards (table 1l). The ammonia samples were consistently isotopically light $(-21 \%$ ) and the average isotopic difference between the ammonia and the soil nitrate was approximately $38 \%$, which suggests that the equilibrium isotope reaction between $\mathrm{NH}_{3}$ (gas) and $\mathrm{NH}_{4}$ (aq) is the controlling reaction. 
Table 11. Ammonia volatilization

\begin{tabular}{|c|c|c|c|}
\hline \multirow{2}{*}{\multicolumn{2}{|c|}{ Location }} & \multicolumn{2}{|c|}{$\delta N^{15}$} \\
\hline & & $\begin{array}{c}\mathrm{NH}_{3} \\
(0 / 00)\end{array}$ & $\begin{array}{c}\mathrm{NO}_{3} \\
(0 / 00)\end{array}$ \\
\hline Barnyard, Runnels & County, Texas & $-21 \cdot 6$ & $+13 \cdot 8$ \\
\hline Feedlot, Austin, & Texas & $-21 \cdot 0$ & \\
\hline Feedlot, Austin, & Texas & $-21 \cdot 3$ & $+19 \cdot 5$ \\
\hline
\end{tabular}


A kinetic isotope fractionation would cause a wide range of $\delta N^{15}$ values for gaseous ammonia. The close correlation of a $\delta \mathrm{N}^{15}$ of $+35^{\circ} \%$ from this study with Kirshenbaum et al. (1947) $+34 \%$ for the same reaction suggests that this is the only significant fractionation controlling the $\delta \mathrm{N}^{15}$ of the nitrate. Fractionation by nitrification or denitrification at the soil surface is not considered important because the $\delta \mathrm{N}^{15}$ difference would have to be significantly greater than $+34 \%$ if additional fractionation from denitrification occurs and less than $+34 \%$ if additional fractionation from nitrification occurs. Fractionation by denitrification deeper in the soil profile is not occurring because the $\delta N^{15}$ remains constant with depth (fig. 6, p. 37). Similarly, fractionations by chromatographic separations (of either $\mathrm{NH}_{4}$ or $\mathrm{NO}_{3}$ ) are not occurring because of the consistency of $\delta \mathrm{N}^{15}$ with depth. Fractionations by reactions within mammals excreting urine may also be important in determining the $\delta \mathrm{N}^{15}$ of the soil nitrate. Gaebler et al. (1966) showed that proteins become enriched in $\mathrm{N}^{15}$. Presumably, excreted nitrogen would have to be isotopically lighter to maintain an isotope mass balance:

$$
\begin{aligned}
& \text { Moles } \mathrm{N}^{14}+\text { Moles } \mathrm{N}^{15} \text { (ingested) }= \\
& \left(\text { Moles } \mathrm{N}^{14}+\operatorname{Moles} \mathrm{N}_{(\text {protein })}+\left(\text { Moles } \mathrm{N}^{14}+\underset{\text { Moles } \left.\mathrm{N}^{15}\right)}{\text { (excreted }}\right.\right. \\
& \text { nitrogen) }
\end{aligned}
$$


The nitrogen pathway from ingested protein to nitrate is:

$$
\begin{aligned}
& \stackrel{N}{n}_{3}(-21 \% 00)
\end{aligned}
$$

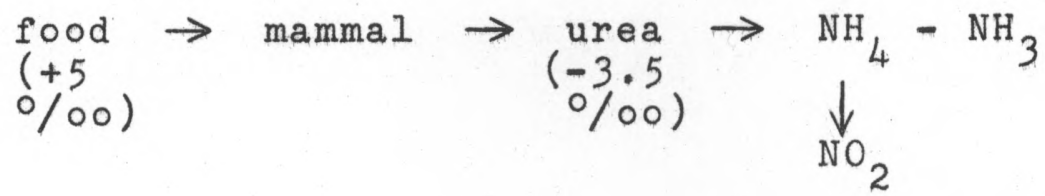

$$
\begin{aligned}
& \mathfrak{N O}_{3}(+14 \% 00)
\end{aligned}
$$

Using this diagram with some simple assumptions, it can be shown that isotopic fractionation is possible within the animal. Assuming that the only fractionation involved in the decomposition of urea to nitrate is ammonia volatilization (ammonia gas-ammonium equilibrium) then the original urea should have a $\delta \mathrm{N}^{15}$ value of $-3.5 \%$ :

$$
\frac{\delta \mathrm{N}^{15}\left(\mathrm{NH}_{3}\right)+\delta \mathrm{N}^{15}\left(\mathrm{NO}_{3}\right)}{2}=\frac{(-2 \mathrm{I})+(+14)}{2}=-3.5 \%
$$

The ingested protein is probably $+5 \%$, the $\delta N^{15}$ of ingested protein used by Gaebler et al. (1966). If the ingested protein is $+5 \%$ and the excreted urea is $-3.5 \%$, the enrichment of $\mathrm{N}^{15}$ may occur within the animal. The assumption that ammonia-ammonium equilibrium ( 1 molecule $\mathrm{NH}_{3}$ to 1 molecule $\mathrm{NH}_{4}$ ) is the controlling reaction is not entirely arbitrary. The consistency of the $6 N^{15}$ values for gaseous ammonia suggests this, and also indicates that a kinetic fractionation 
is not involved. The $\delta N^{15}$ of the original urea then has to be approximately $-3 \%$. An $8 \%$ fractionation within the animal is only conjecture, however, because the urea accounts for about $50 \%$ of the excreted nitrogen ( $70 \%$ excreted $N$ is in urine, 70\% urine $\mathrm{N}$ is in urea). Nothing is known about the isotopic composition of the other 50\% of excreted nitrogen. Most of this nitrogen will be in an undigested form in the feces, and may not be important to the biochemical and isotope systems of the body.

The isotopic fractionations controlling the $\delta N^{15}$ of soils contaminated by animal waste material appear to be ammonia volatilization and a reaction within the animal excreting the nitrogen. Isotopic fractionations caused by nitrification, denitrification, and chromatographic separation do not appear to be important.

Soils from cultivated fields with no animal wastes.-The predominant source of nitrate in cultivated soils with no animal waste or fertilizer is from the oxidation of soil humus turned over by plowing. Cultivated or fallow fields have appreciably higher nitrate concentrations than grasslands such as pastures and virgin prairies (Smith and Vandecaveye, 1946; Thompson et al., 1954; Haas et al., 1957; Kononova, 1961; Vazhenin and Vazhenina, 1969). The enriched $\mathrm{N}^{15}$ tracer study of Bartholomew and Clark (1950) showed a faster breakdown of the stable humus in cultivated soils than in uncultivated 
fields. Figure 16 shows the decrease in organic nitrogen in cultivated soils as it is oxidized to nitrate. The low nitrate concentrations in grasslands have been attributed to toxic effects of grass roots on bacteria (Theron, 1951; Stiven, 1952; Boughey et al, , 1964) and to direct competition by grasses for any $\mathrm{NH}_{4}$ produced (Robinson, 1963). Aerobic bacteria are more numerous in cultivated soils than in grassland soils (Chase et al., 1967). Birch (1959a, 1959b), Soulides and Allison (1961), and Moore and Russel (1970) have measured considerable increases in $\mathrm{NH}_{4}$ and $\mathrm{NO}_{3}$ by wetting and drying of aerated agricultural soils. Table 12 shows the much greater concentration of $\mathrm{NO}_{3}$ in cultivated and fallow fields in comparison to grasslands.

Mineralization of soil humus in cultivated fields should occur throughout the year, but at greater rates in summer because of the higher temperatures. Birch (1959a) found that higher temperatures increased mineralization. However, higher nitrate concentrations occur during the fallow seasons, winter and early spring, because there are no crops to assimilate ammonium and nitrate (Soulides and Allison, 1961).

Nitrogen fixation rapidly increases the total nitrogen in fields planted with white or red clover (legumes), whereas in grasslands the total nitrogen increases very slowly. The increase is also attributed to nitrogen fixation, but the rates must be lower (Cooke, 1967). 


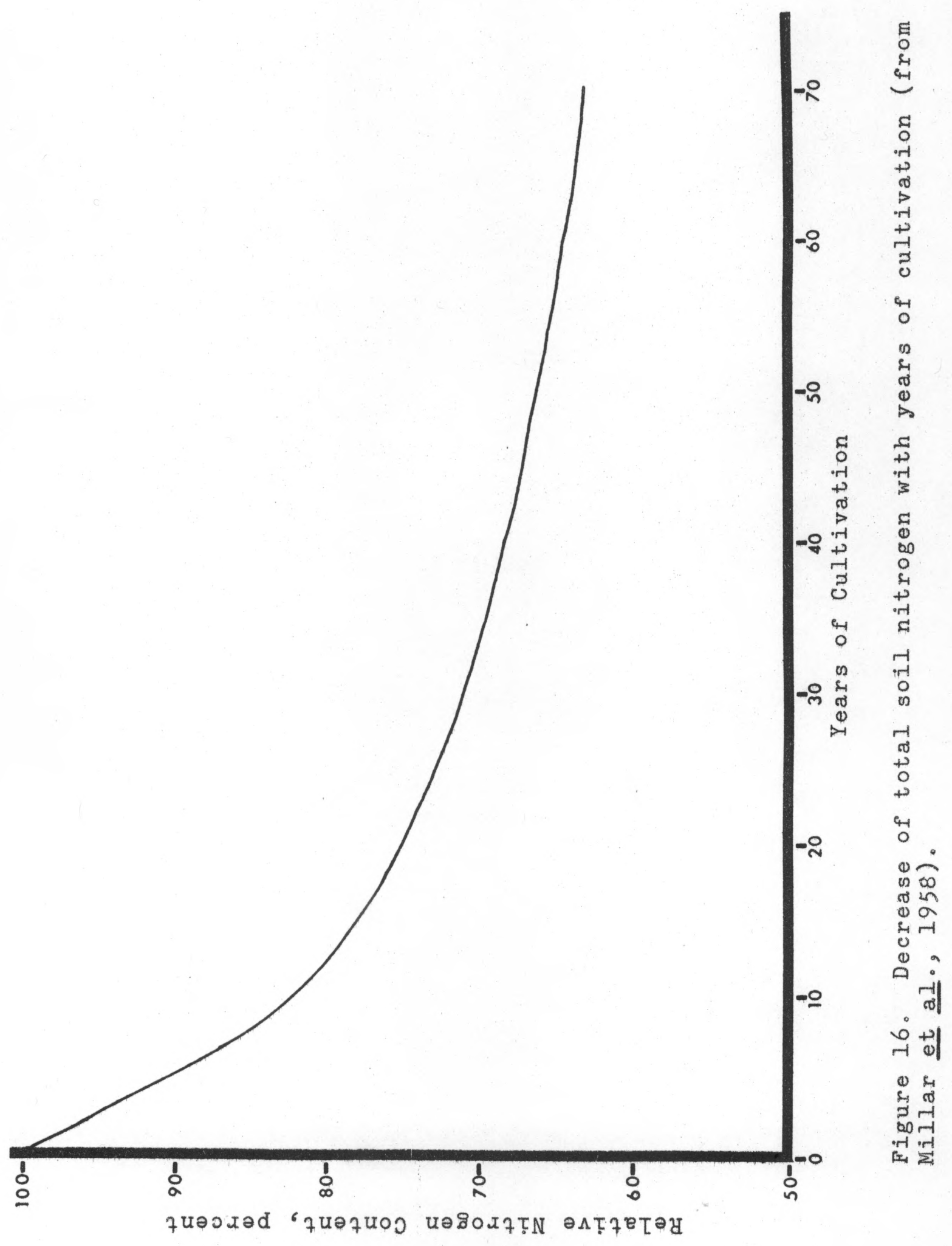




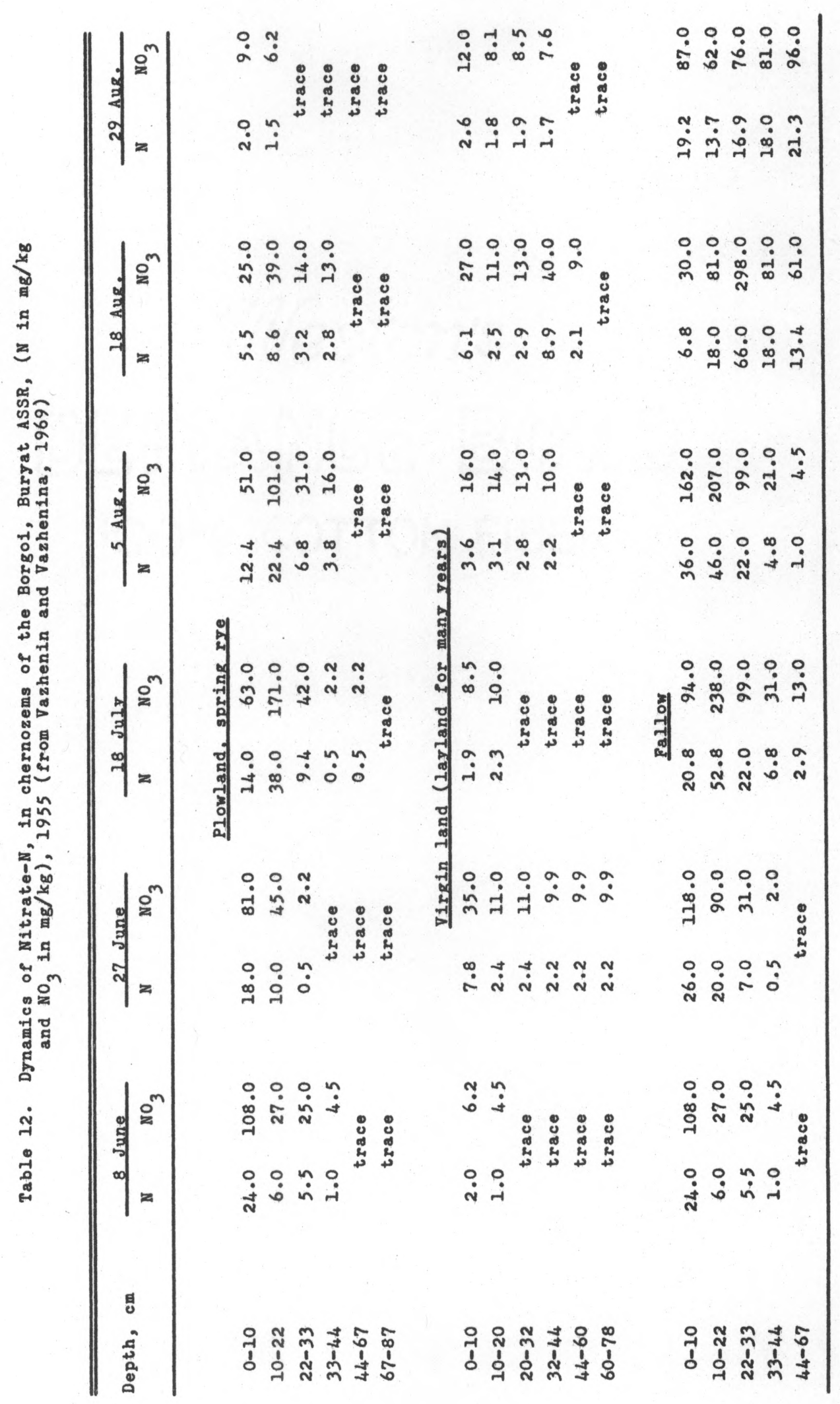


Ammonium and nitrate are present in rain, but in low concentrations. Junge (1958) found ammonium concentrations of 0.01 to $0.12 \mathrm{mg} / 1$ and nitrate concentrations of 0.47 to $1.0 \mathrm{mg} / \mathrm{l}$ in rain in Texas in 1956. The source of most of the nitrate and ammonium in the atmosphere probably is wind erosion of cropland. Thus ammonium and nitrate in rain water are probably only the result of recycling soil nitrogen back to the soil and not the addition of new nitrogen from the atmosphere. The nitrate in the soil is the result of the "mineralization" of the organic nitrogen of the humus and not the nitrogen produced by nitrogen fixation or precipitation.

The $\delta N^{15}$ of nitrate from cultivated fields with no animal waste in Runnels County is $+2 \%$ to $+8 \%$ ( $\mathrm{fig} .8, \mathrm{p}$. 39). This is in the same isotopic range as other published $\delta N^{15}$ values for natural soil nitrate (Cheng et al., 1964; Bremner and Tabatabai, 1973; Edwards, 1973) (table 9, p. 63). The nitrate data from these authors are the result of incubation and not "field" sampling. Cheng et al. (1964), Bremner and Tabatabai (1973), and Edwards (1973) observed that total nitrogen of soil humus was isotopically heavier than the incubated nitrate. The close correlation between the data of this study and the incubated-nitrate data suggests that the mechanisms of fractionation are the same. Fractionation during mineralization (incubation) appears to be the mechanism for producing a lighter $\delta \mathrm{N}^{15}$ of the $\mathrm{NO}_{3}$ from the heavier $\delta \mathrm{N}^{15}$ 
of the total nitrogen of the humus. The reactions of mineralization are nitrification and decomposition of the organic nitrogen of the humus to ammonium. The organic nitrogen in humus is either in protein or amino acid form, and is the result of microbial biosynthesis of chlorophyllaceous plants and not residual plant material (Millar et al., 1958). There may be an isotopic fractionation between these metabolic byproducts and ammonia. Tables 12 and 13 indicate considerable mineralization of the nitrate ion with little accumulation of $\mathrm{N}$ as $\mathrm{NH}_{4}$. This means that the nitrification reaction is going to completion and is thus preventing fractionation. If a nonequilibrium reaction goes to completion, there cannot be a kinetic isotopic fractionation. The fractionation has to be caused by the decomposition of the organic nitrogen to ammonia. Denitrification is not important in controlling the isotope mass balance if the fractionation is caused by mineralization. Significant denitrification would cause the nitrate to become isotopically heavier rather than becoming lighter as observed. Soils in semiarid regions, such as Runnels County, Texas, probably do not undergo appreciable denitrification because of the low soil moisture. Denitrification does not occur unless soil moisture content is greater than $60 \%$ to $70 \%$ of the water-holding capacity (Cooke, 1967). Denitrification may be important in controlling the $8 \mathrm{~N}^{15}$ of soil nitrate in wetter climates, or in irrigation farming, 
Table 13. Dynamics of water-soluble ammonium-N, in chernozem soil, Borgoi, Buryat, ASSR, 1955, in mg/kg (from Vazhenin and Vazhenina, 1969)

Depth, $\mathrm{cm}$

8 June 27 June 18 July 5 Aug. 18 Aug. 27 Aug.

\section{Clean fallow}

$\begin{array}{rrrrrrr}0-10 & 2.2 & 1.1 & 1.9 & 1.0 & 1.0 & 1.2 \\ 10-22 & 1.8 & 1.0 & 1.3 & 1.0 & 1.2 & 1.5 \\ 22-33 & 1.5 & <1.0 & 1.0 & <1.0 & <1.0 & 1.2 \\ 33-44 & <1.0 & <1.0 & <1.0 & <1.0 & <1.0 & 1.0 \\ 44-67 & <1.0 & <1.0 & <1.0 & <1.0 & <1.0 & <1.0\end{array}$

\section{Plowland, spring rye}

$\begin{array}{rrrrrrr}0-10 & 2.2 & 1.2 & 1.5 & 1.0 & 1.3 & 1.0 \\ 10-22 & 1.8 & 1.2 & 1.2 & 1.0 & 1.0 & 1.2 \\ 22-33 & 1.5 & 1.0 & <1.0 & <1.0 & 1.2 & 1.0 \\ 33-44 & <1.0 & <1.0 & <1.0 & <1.0 & <1.0 & 1.0 \\ 44-67 & <1.0 & <1.0 & <1.0 & <1.0 & <1.0 & <1.0 \\ 67-87 & <1.0 & <1.0 & <1.0 & <1.0 & <1.0 & <1.0\end{array}$

\section{Virgin land (layland for many years)}

\begin{tabular}{rrrrrrr}
$0-10$ & 2.1 & 2.9 & 3.0 & 2.6 & 1.8 & 2.3 \\
$10-20$ & 1.8 & 2.8 & 2.8 & 2.5 & 1.6 & 1.8 \\
$20-32$ & 1.5 & 1.6 & 2.4 & 2.1 & 1.2 & 1.3 \\
$32-44$ & 1.3 & 1.1 & 1.2 & 1.0 & 1.0 & 1.0 \\
$44-60$ & 1.2 & 1.0 & 1.0 & 1.2 & 1.0 & 1.2 \\
$60-78$ & $<1.0$ & $<1.0$ & 1.0 & 1.0 & $<1.0$ & 1.0 \\
\hline
\end{tabular}


Ammonia volatilization is not important because the soil $\mathrm{pH}^{\prime} \mathrm{s}$ are not high enough for adequate ammonia volatilization, and no urea is hydrolyzed to form a strong base. The decomposition of organic nitrogen, other than urea, does not produce a high base/acid ratio, thus the $\mathrm{pH}$ would not be expected to rise. Hooker et al. (1973) observed no ammonia losses from cultivated fields. If mineralization is the controlling fractionation, then ammonification also would leave nitrate isotopically heavier than observed.

The $\delta N^{15}$ profiles beneath cotton fields and adjacent turnroads, where $\mathrm{NO}_{3}$ concentrations are much higher, cannot be used to determine the importance of nutrient assimilation because all samples were collected in winter and spring. The nitrate in the soils probably was generated during the fallow season and none had as yet been used as plant nutrient. Studying these same soils in late summer or fall would indicate whether assimilation is an important isotopic fractionation.

Chromatographic separations of nitrate do not appear important in controlling the $\delta \mathrm{N}^{15}$ of these profiles. The $\delta \mathrm{N}^{15}$ of the nitrate remains relatively constant with depth. In general, soils do not have a high anion exchange capacity. There is the possibility of an isotopic fractionation between aqueous ammonium ions and adsorbed ammonium on clays. A chromatographic separation would result in the $\mathrm{N}^{15} \mathrm{H}_{4}$ being 
preferentially adsorbed (Delwiche and Steyn, 1970). The isotopically lighter $\mathrm{NH}_{4}$ would then be nitrified to an isotopically light nitrate relative to the heavier organic nitrogen. A comparison of ammonium adsorbed on clay minerals and aqueous ammonium (table 14) shows either no fractionation in Grundy, Hayden, and Austin soils or a slight depletion of $\mathrm{N}^{15}$ in adsorbed ammonium in Clarion and Glencoe soils. This is the opposite from what Delwiche and Steyn (1970) observed.

Cheng et al. (1964) and Bremner and Tabatabai (1973) observed that organic soil nitrogen is isotopically heavier than atmospheric nitrogen. This is a result of either the addition of isotopically heavy nitrogen to the soil system or of the removal of isotopically light nitrogen from the soil system. The addition of heavy nitrogen through nitrogen fixation is not likely because of the lack of fractionation (Hoering and Ford, 1960) or a slight fractionation preferring $\mathrm{N}^{14}$ (Delwiche and Steyn, 1970). Light nitrogen must be removed from the soil system by either organic nitrogen mineralization, denitrification, or ammonification.

If the mineralization of organic nitrogen in cultivated soils produces an isotopically light nitrate, then the residual organic nitrogen will become heavier. The isotopically lighter $\mathrm{NO}_{3}$ can be leached below the root zone or adsorbed as a nutrient and harvested as a crop. Light nitrogen is removed from the system permitting the $\delta N^{15}$ of the total 
Table 14. $\delta \mathrm{N}^{15}$ of various forms of nitrogen in soils (from Cheng et al., 1964)

\begin{tabular}{|c|c|c|c|c|c|}
\hline \multirow{2}{*}{ Nitrogen Form } & \multicolumn{5}{|c|}{ Soil Type } \\
\hline & $\overline{\text { Grundy }}$ & Hayden & Austin & Clarion & Glencoe \\
\hline & & & $6 N^{15}(0$ & o) & \\
\hline Total - N & +16 & +7 & +5 & +3 & +2 \\
\hline Hydrolyzable & +18 & +10 & +7 & +5 & +4 \\
\hline Ammonium & +7 & +7 & +3 & +6 & +5 \\
\hline Hexosamine & +25 & +8 & 0 & +2 & -2 \\
\hline Amino acid & +16 & +14 & +12 & +5 & +8 \\
\hline Hydroxyamine acid & +19 & +11 & +8 & +7 & +3 \\
\hline Nonhydrolyzable & -3 & -2 & -1 & 0 & +1 \\
\hline $\mathrm{N}$ - mineralized & +6 & +2 & +1 & +1 & +1 \\
\hline Fixed ammonium & +6 & +6 & +4 & +2 & 0 \\
\hline
\end{tabular}


nitrogen to become heavier. With time, both the $\delta \mathrm{N}^{15}$ of the nitrate and of the residual total nitrogen will become heavier. If this is true, then grasslands with no animal wastes and no cultivation should have $\delta N^{15}$ values of total nitrogen close to 0.0 or slightly negative. The nitrogen added by fixation will be isotopically identical or slightly lighter than atmospheric nitrogen, and there will be little loss of nitrogen through mineralization. This increase in $\delta N^{15}$ of total nitrogen in cultivated fields was found by Bremner and Tabatabai (1973), who analyzed three pairs of soils, each pair containing a cultivated soil and a soil in its virgin state. All the cultivated soils were isotopically heavier than their virgin counterparts (table 15).

Denitrification probably is not the controlling reaction even though nitrogen is lost from anaerobic soil environments with kinetic isotope fractionation factor of 1.02 (Wellman, Cook, and Krouse, 1968; Delwiche and Steyn, 1970; Myaka and Wada, 1971). Denitrification reduces the oxidized species of nitrate and nitrite to nitrogen gas and nitrous oxides, but should not affect the organic nitrogen because it is in a more reduced state than the atmospheric nitrogen. Denitrification should not directly affect the $\delta \mathrm{N}^{15}$ of the organic nitrogen. It may enrich the organic nitrogen if some of the nitrate is lost by reduction leaving a residual heavy nitrate which would then be cycled back to the soil humus by 
Table 15. $\delta N^{15}$ differences between total nitrogen

of cultivated soils and virgin soils

(from Bremner and Tabatabai, 1973)

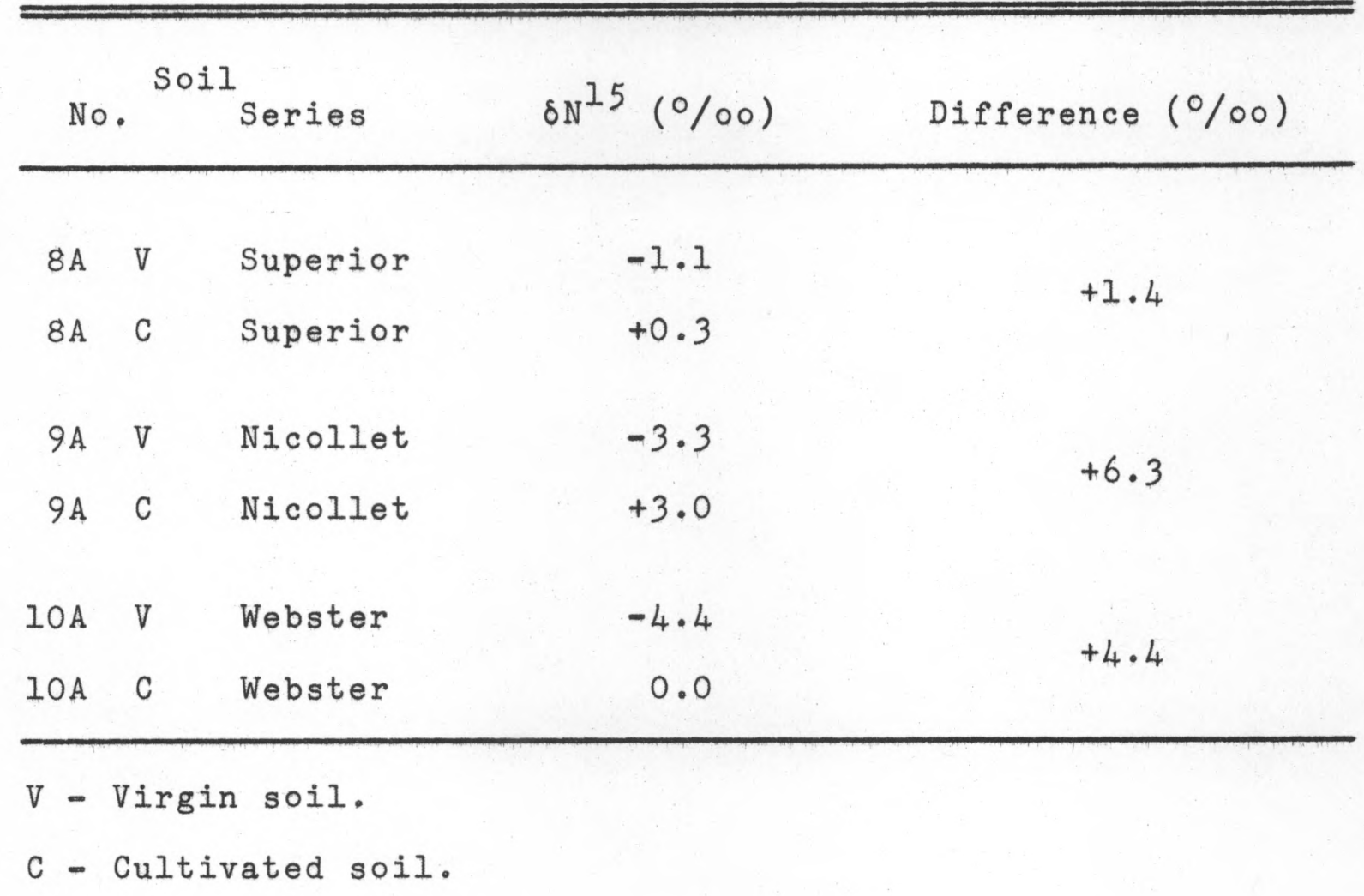


plant nutrient absorption and plant decay. However, no evidence suggests denitrification is occurring in the Runnels County soils.

Soils may be classified into three groups according to nitrogen isotope ranges: soils with animal waste, soils that have been cultivated, and soils still in their virgin grassland state. The isotopic composition of soil with animal waste will be controlled by ammonia volatilization. The isotopic composition of cultivated soils will be controlled by the mineralization of soil humus. The virgin grassland soils will be controlled by nitrogen fixation. 


\section{ISOTOPIC COMPOSITION OF NITROGEN FERTILIZERS}

Synthetic nitrogen fertilizers have a $\delta N^{15}$ composition close to the nitrogen isotope ratio of atmospheric nitrogen. The $\delta N^{15}$ range of fertilizer overlaps the $\delta N^{15}$ range of natural soil nitrate. This may prevent distinguishing by isotopic analysis the nitrate from the mineralization of organic nitrogen in soil from the nitrate of fertilizers (Riga et al., 1971; Hauck et al., 1972; Hauck, 1973; Edwards, 1973).

Commoner (1970a) analyzed four commercial fertilizers having $\delta \mathrm{N}^{15}$ values of $-4.6 \%$ to $+3.0 \%$ (table 16). Kent Murman (personal communication, June 1973) found a similar range for ammonium nitrate fertilizers. Dr. Murman has requested that his data not be released at this time. Edwards (1973) analyzed $\left(\mathrm{NH}_{4}\right)_{2} \mathrm{SO}_{4}$ and aqua-ammonia and found $8 \mathrm{~N}^{15}$ values of $-5.00 \%$ and $-60 \%$ respectively (table 16).

Kohl et al. (1971) used $\delta N^{15}$ of $+3 \% / 00$ for nitrogen fertilizers and $+13 \%$ for natural soil nitrate to demonstrate that the high nitrates in Lake Decatur, Decatur, IIIInois, were the result of fertilizer nitrate and not natural soil nitrate. This research has not been accepted, however, because the value of $+13 \%$ o for natural soil nitrogen has not been substantiated (Hauck et al., 1972; Hauck, 1973; Edwards, 1973; Bremner and Tabatabai, 1973). Edwards (1973) found an average $\delta N^{15}$ of $+4.9 \%$ for ten analyses of samples 


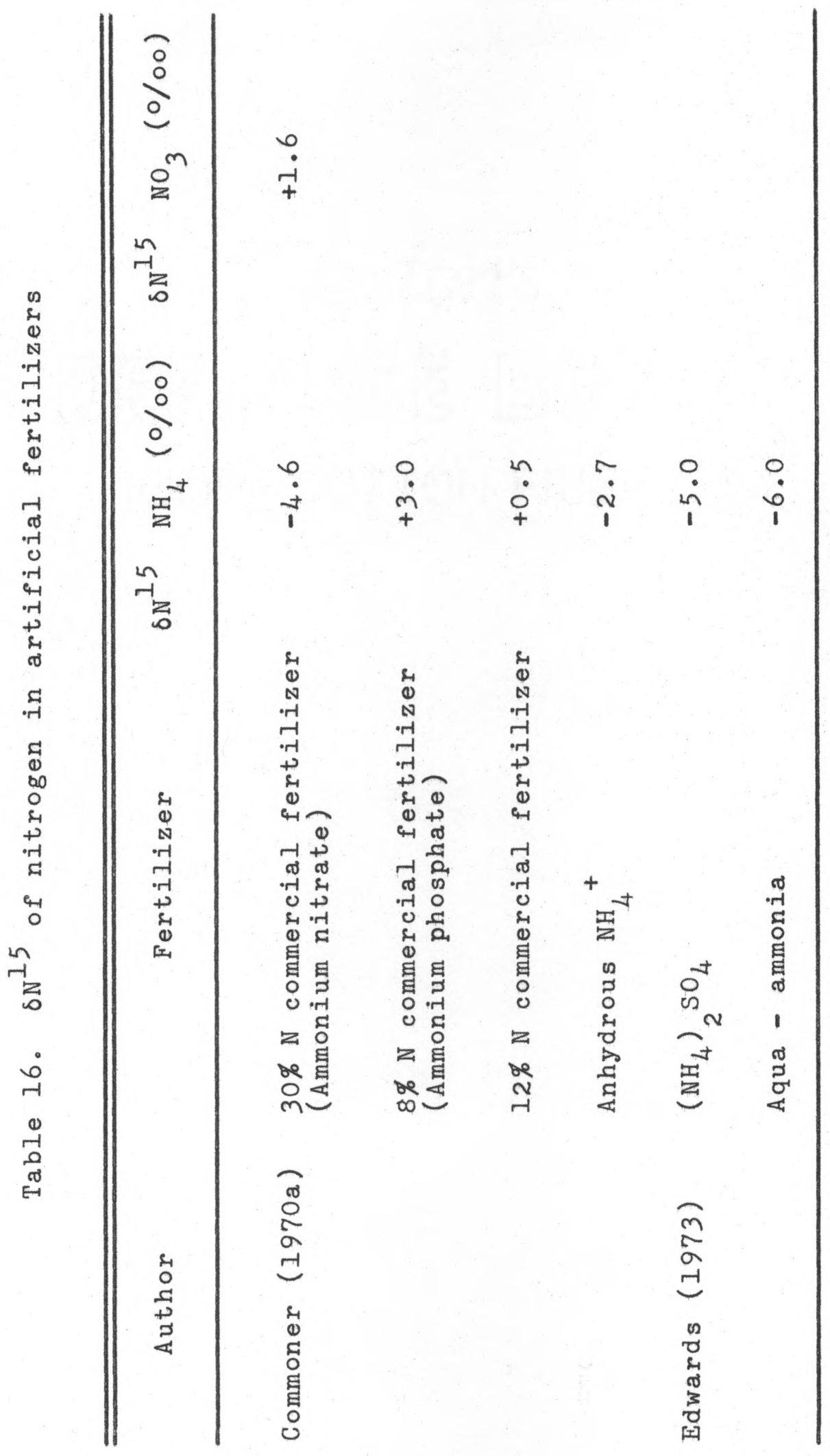


from the mineralization of organic nitrogen from a soil with no fertilizer. Incubated nitrate from the same soil with $\left(\mathrm{NH}_{4}\right)_{2} \mathrm{SO}_{4}$ or aqua-ammonia had an average $\delta \mathrm{N}^{15}$ of total nitrogen from controlled agricultural plots, one with fertilizer and one with no fertilizer, showed a slightly lighter $\delta \mathrm{N}^{15}$ in the soil without fertilizer, approximately $1.5 \%$ (Riga et a.1., 1971). 
$\delta \mathrm{N}^{15}$ OF GROUNDWATER $\mathrm{NO}_{3}$ VERSUS $\delta \mathrm{N}^{15}$ OF SOIL $\mathrm{NO}_{3}$

Nitrate in groundwater can originate from numerous sources. The spectrum varies from completely natural phenomena such as bat guano in cave deposits (Feth, 1966), to entirely man-made phenomena such as leaking sewer lines (Kimmel, 1972). Feth (1966) and Viets and Hageman (1971) presented comprehensive reviews of various sources of nitrate in groundwater.

Many sources providing large quantities of nitrate to groundwater probably are the result of human activity. Table 17 shows the nitrate concentrations of water in aquifers of central Texas. Waters in deeper portions of the aquifers typically contain less than $0.5 \mathrm{mg} / \mathrm{INO}_{3}$, whereas waters in the recharge zones average above $10 \mathrm{mg} / 1 \mathrm{NO}_{3}$. The high nitrate in the shallow groundwater is the result of the activities of man, whether it be excess fertilizer usage, oxidation of the soil humus, or leaching livestock and human wastes.

The lower concentrations of nitrate may be the result of denitrification. This explanation is not probable, though still possible. For biologic denitrification to occur there must be an adequate supply of denitrifying bacteria and a source of organic carbon (Martin and Goff, 1972). The organic carbon may be in the deeper parts of the aquifer as the result of original depositional processes; however, it is not likely 


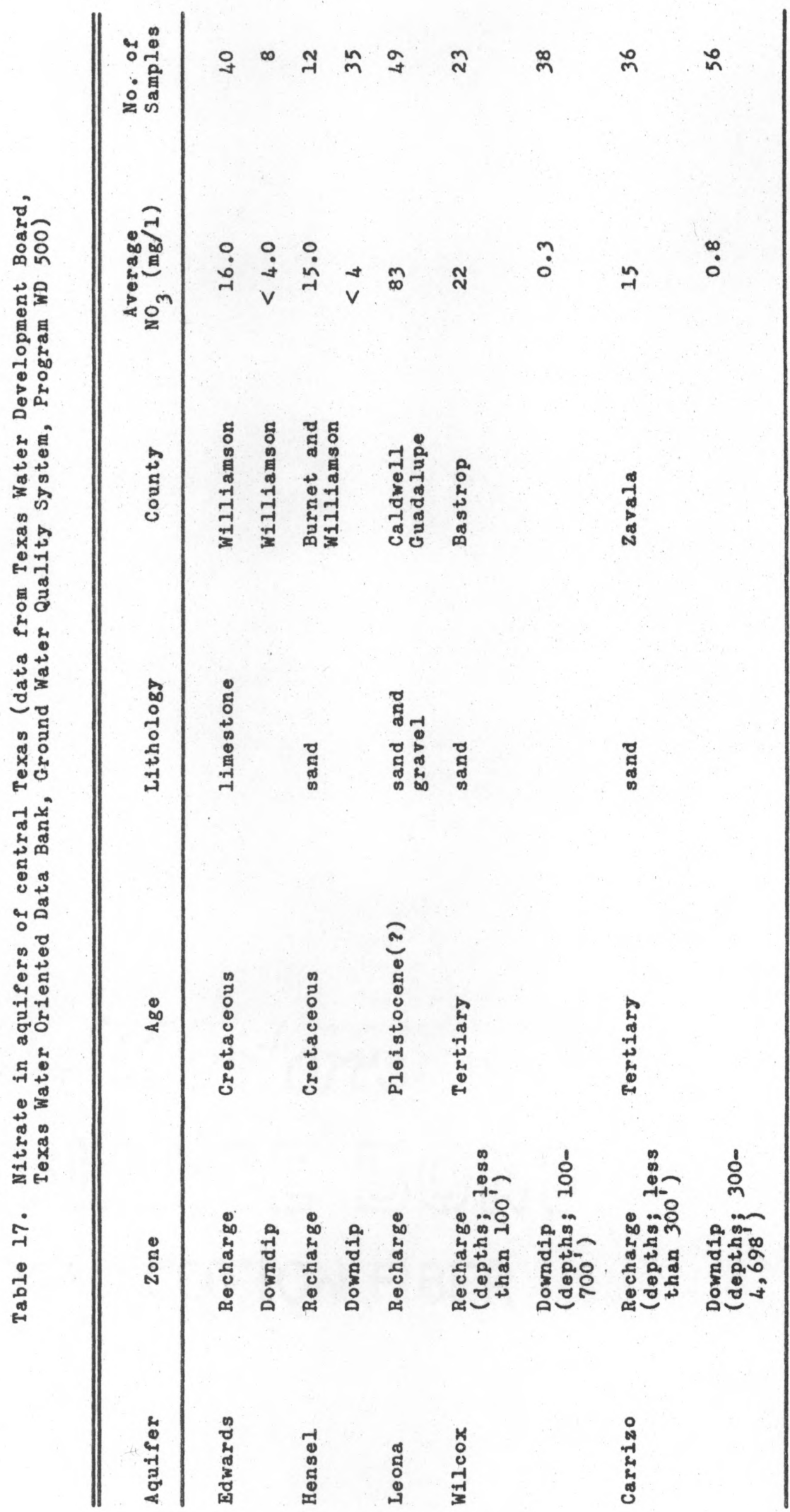


that adequate numbers of anaerobic bacteria exist.

Considering only the sources related to human activity, researchers have attributed nitrate in surface waters and groundwaters to high nitrate in rainfall (Junge, 1958), fertilizers (Commoner, 1970b), animal waste material (Smith, 1969; Gillham and Webber, 1969), nitrogen fixation, cultivation (Stout and Burau, 1967), septic tanks (Walker et al., 1973a, 1973b), leaking sewer lines (Kimmel, 1972), and spray irrigation of sewage effluent (Nuhou Kumu Wai, 1972; King, 1973). Most of these studies did not determine the relative importance of a particular source because generally there was more than one source available, and classical chemical techniques could not separate them. The extremely soluble nature of nitrate permits easy migration away from its source, which commonly separates it from other identifiable tracers, as, for example, septic tank pollutants migrating in an aquifer. Fecal bacteria may be filtered out and phosphates may be adsorbed, but the nitrate remains in solution and migrates through the aquifer. No conventional chemical technique can trace this nitrate back to the septic tank.

Statistical approaches also have been tried with a similar lack of success. Sylvester (1959), Commoner (1970b), and Jaworski et al. (1971) have tried to determine the relative contribution from various sources by studying the amount of fertilizer used, the number of septic tanks per acre, or 
the per capita flush of a toilet. Their numbers are no more than rough estimates because they have no way to validate their conclusions.

By studying the natural nitrogen isotope ratios of nitrate in groundwater and comparing them to the nitrogen isotope ratios of nitrate from different soil environments, the nitrate of certain groundwaters can be traced to unique sources. I determined $\delta N^{15}$ values of nitrate from groundwaters in southern Runnels County, Texas, Macon County, Missouri, and Long Island, New York, and compared them to the soil nitrate of southern Runnels County, Texas. Runnels County was the main area of study because of the previous research done there (Kreitler, 1972). Macon County, Missouri, was chosen because Smith (1969) thought the major source of nitrate was animal waste material, and Long Island, New York, was chosen because the source of nitrate varied from place to place.

\section{Southern Runnels County, Texas}

\section{Levels of nitrate contamination.--Ninety percent of} water samples analyzed by Kreitler (1972) had nitrate concentrations greater than $45 \mathrm{mg} / 1$ as nitrate. The highest nitrate concentration measured was $3,100 \mathrm{mg} / \mathrm{I}$.

Hydrogeology.--Groundwater is pumped from shallow Permian carbonate aquifers of the Wichita-Albany and Clear Fork 
Groups. Water occurs in the Talpa Formation ( 400 feet of shales and limestones), the Clyde Formation (530 feet of shales, marly limestones, and resistant limestones), the Leuders Formation ( 190 feet of limestone and shales), and the Arroyo Formation (260 feet of shale, limestone, and basal lenses of gypsum). The rocks strike northeast and dip to the northwest approximately 40 feet per mile $(7.6$ $\mathrm{m} / \mathrm{km})$ (Kreitler, 1972).

Significant groundwater flow is restricted to solution cavities along bedding plane surfaces, joint surfaces, and solution cavities in dense limestone beds. Analyses of two aquifer pump-tests on the limestones yielded transmissivities of $670 \mathrm{gallons} / \mathrm{day} / \mathrm{foot}\left(1.0 \mathrm{~cm}^{2} / \mathrm{sec}\right)$ and 15,000 gallons/day/foot $\left(21.9 \mathrm{~cm}^{2} / \mathrm{sec}\right)$, and coefficients of storage of $4 \times 10^{-4}$ and $5 \times 10^{-6}$, respectively. Well yields are generally less than 100 gallons per minute (6.3 liters/sec). Few wells are deeper than 100 feet $(30.4 \mathrm{~m})$.

\section{Land-use practice.--The economy of Runnels County} is based on the production of cotton, wheat, sorghum, corn, cattle, hogs, and sheep. In $1970,27,500$ bales of cotton, 513,000 bushels of wheat, and $1,672,800$ bushels of sorghum were harvested (Texas Almanac, 1973). Approximately 90\% of the land in southern Runnels County is "dry farmed" for these crops. Irrigation is rare because of the lack of acceptable quantities of groundwater. After the drought of 
the $1950^{\prime} \mathrm{s}$, the U. S. Soil Conservation Service, a branch of the U. S. Department of Agriculture, encouraged the terracing of much of the farm land of southern Runnels County for maximum retention of rainfall. According to the farmers of the area, the water table rose appreciably after terracing.

Herds of cattle and flocks of sheep are small, and hog farms are few. More livestock are raised in the northern part of the county, whereas farming is the main occupation in southern Runnels County.

First-generation and second-generation East Europeans still farm most of the land. In the $1920^{\prime} \mathrm{s}$ there was a family on every "forty acres," whereas the average size farm in 1964 was 551 acres (Texas Almanac, 1973). The farming population has decreased drastically as it has in many other farming communities.

\section{$\delta \mathrm{N}^{15}$ of nitrate in groundwater.--I determined the} $\delta N^{15}$ of nitrate from 31 different water samples from water wells in southern Runnels County, Texas. Plate 2 shows the well locations. Water well number, location, owner, $\delta N^{15}$ of nitrate, and the nitrate concentrations of samples collected in 1969, 1971, and 1972 are listed in Appendix 2 (p. 128). The water wells selected for sampling have large geographic distribution, high and low nitrate concentrations, and different local land-use, e.g., wells in cotton fields and wells in barnyards. The most important variable is local land use. 
Samples were collected from wells in barnyards (samples 15, 18, 388, 867, and 1034), near farm houses (samples 18, 105, $211,233,234,369,419,551,551 \mathrm{a}, 865,1004$, and 1005), in pastures (samples 67 and 421), and in cultivated fields away from sources of animal waste (samples 16, 165, 201, 309, 366, $386,506,552,728,1002$, and 1003).

One of the original tasks of this research project was to determine whether nitrogen isotopes could be used to trace the nitrate in groundwater to its source. A plot of the groundwater nitrate concentration versus $\delta \mathrm{N}^{15}$ shows a wide spread of $\delta \mathrm{N}^{15}$ values with only a small correlation $(r=0.44)$ of $\delta N^{15}$ with the nitrate concentrations ( $\mathrm{fig} \cdot 17$ ). The groundwaters with the highest $\mathrm{NO}_{3}$ concentrations have the most enriched $\delta N^{15}$ values. However, even the waters with low $\delta N^{15}$ values have nitrate concentrations which exceed the limit recommended by the U.S. Public Health Service. With a linear correlation of nitrate and $\delta \mathrm{N}^{15}$, one source of nitrate would be predominant. High nitrate concentrations with both high and low $\delta N^{15}$ values indicate that there are at least two sources in the samples analyzed, however the sources or their relative importance cannot be determined.

A comparison of the $\delta \mathrm{N}^{15}$ of nitrate in groundwaters under specific land-use areas, for example, barnyards and cotton fields, with the $\delta N^{15}$ of the nitrate from different soil environments identifies the two sources and shows their 


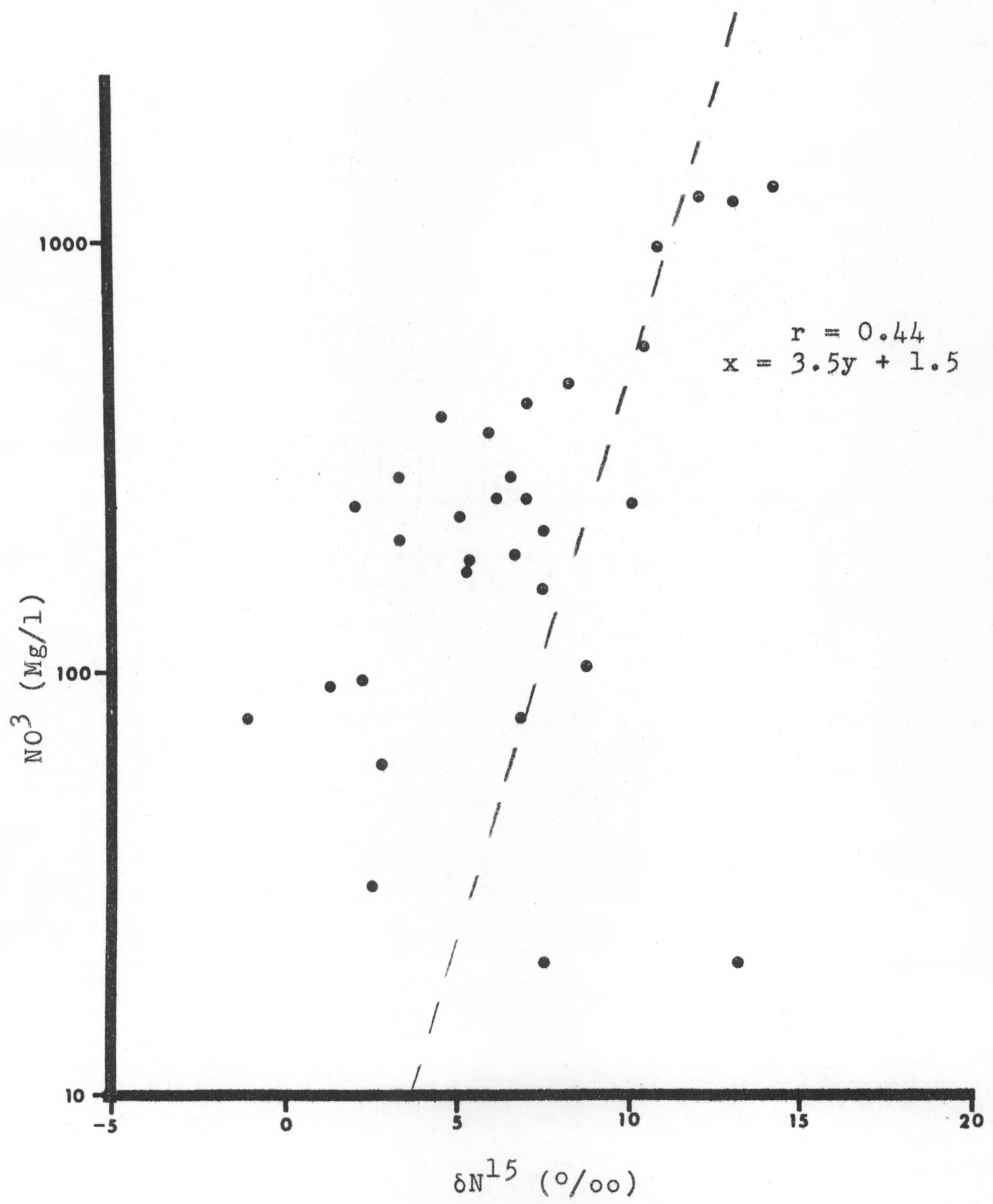

Figure 17. $\delta \mathrm{N}^{15}$ of nitrate in groundwater from Runnels County, Texas. 
relative contribution. By overlaying a frequency distribution graph of $\delta \mathrm{N}^{15}$ in groundwaters beneath cultivated fields with no cattle on the graph of the two $\delta N^{15}$ soil nitrate ranges, there is a remarkable coincidence between the $\delta N^{15}$ of soil nitrate and the $\delta N^{15}$ of groundwater nitrate (fig. 18). An overlay of the frequency distribution of $\delta \mathrm{N}^{15}$ of groundwater nitrate from wells near farmhouses, but not in barnyards, on the two $\delta N^{15}$ soil nitrate ranges shows an isotopic shift toward the animal waste nitrate (fig. 19). The predominant source in this case is nitrate from cultivated fields, as long as the average $\delta N^{15}$ of the groundwater nitrate is below $+90 / 00$. The frequency distribution of $\delta \mathrm{N}^{15}$ of groundwater nitrate from barnyard wells shows a wide range of $\delta N^{15}$ values, indicating that both natural soil nitrate and animal waste nitrate are contaminating the groundwaters beneath barnyards (fig. 20). The predominant source of nitrate in groundwaters beneath barnyards may depend on the influence of the regional hydraulic gradient and on the pumping history of the barnyard well.

The three high $\delta N^{15}$ samples $(388,867$, and 1034) are from barnyard wells located on topographic highs. Kreitler (1972) indicated that the potentiometric surface generally followed the topography. Groundwater flow, and thus nitrate migration, should be away from the barnyard rather than toward it. The soil and water samples from the Halfman farm 


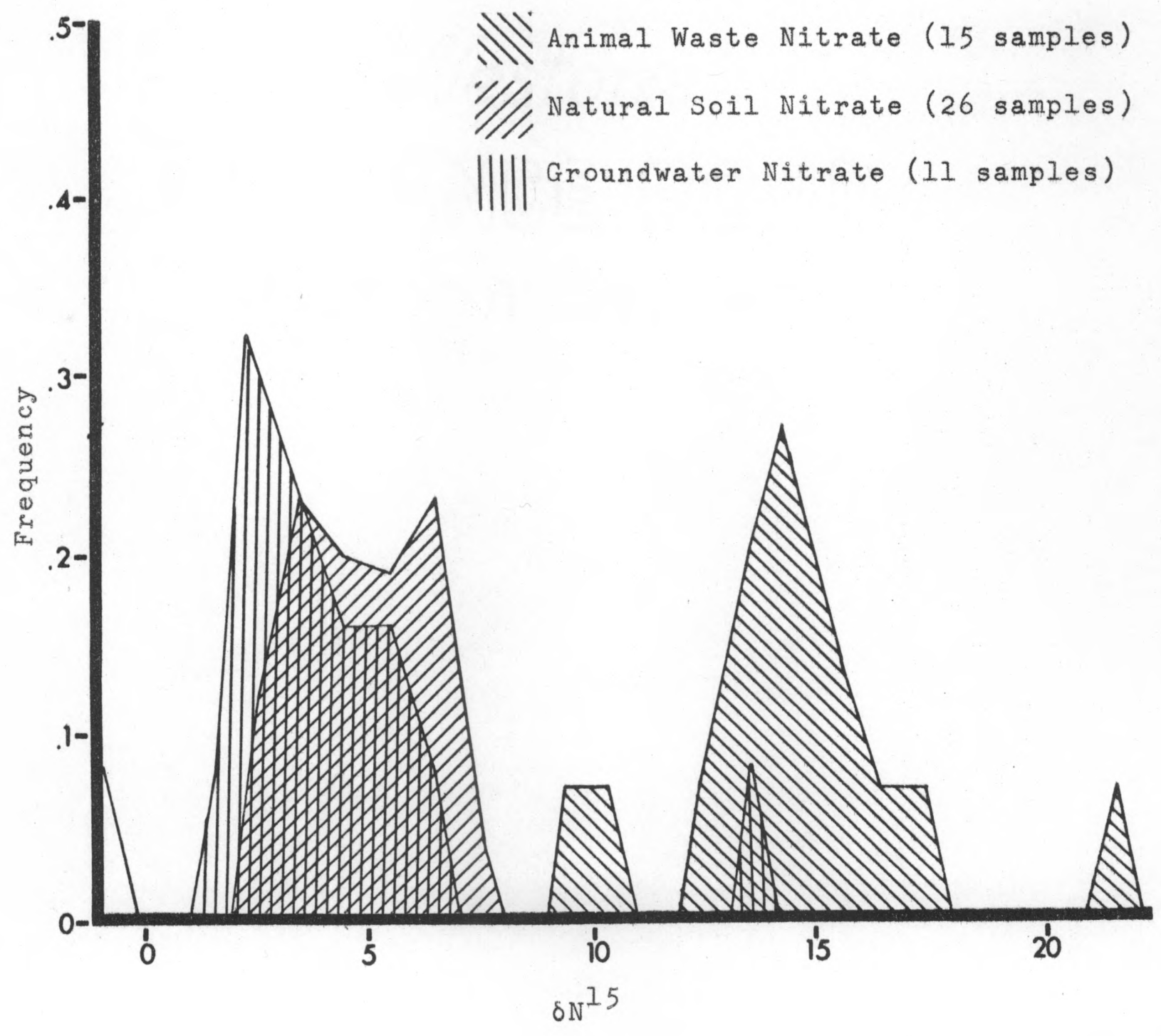

Figure 18. $\delta N^{15}$ of nitrate in groundwater from wells in cultivated fields compared to the $\delta N^{15}$ of natural soil nitrate and animal waste nitrate (Runnels County, Texas). Frequency polygons have class interval of one $\delta N^{15}$ unit. Cumulative frequency of each curve is equal to 1.0 . 


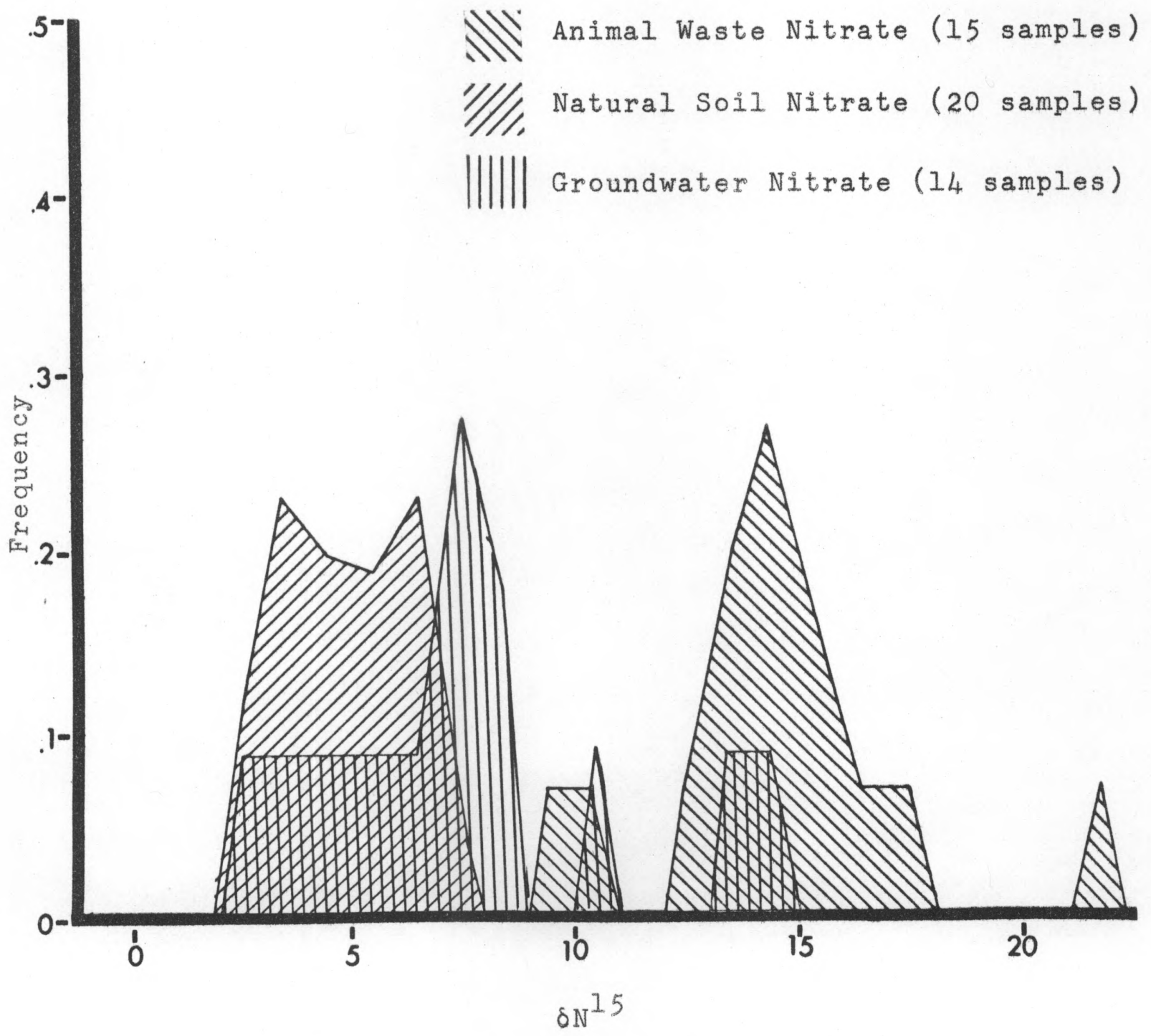

Figure 19. $\delta N^{15}$ of nitrate in groundwater from wells near farmhouses, but not in barnyards compared to $6 \mathrm{~N} 15$ of natural soil nitrate and animal waste nitrate (Runnels County, Texas). Frequency polygons have class interval of one $\delta N^{15}$ unit. Cumulative frequency of each curve is equal to 1.0 . 


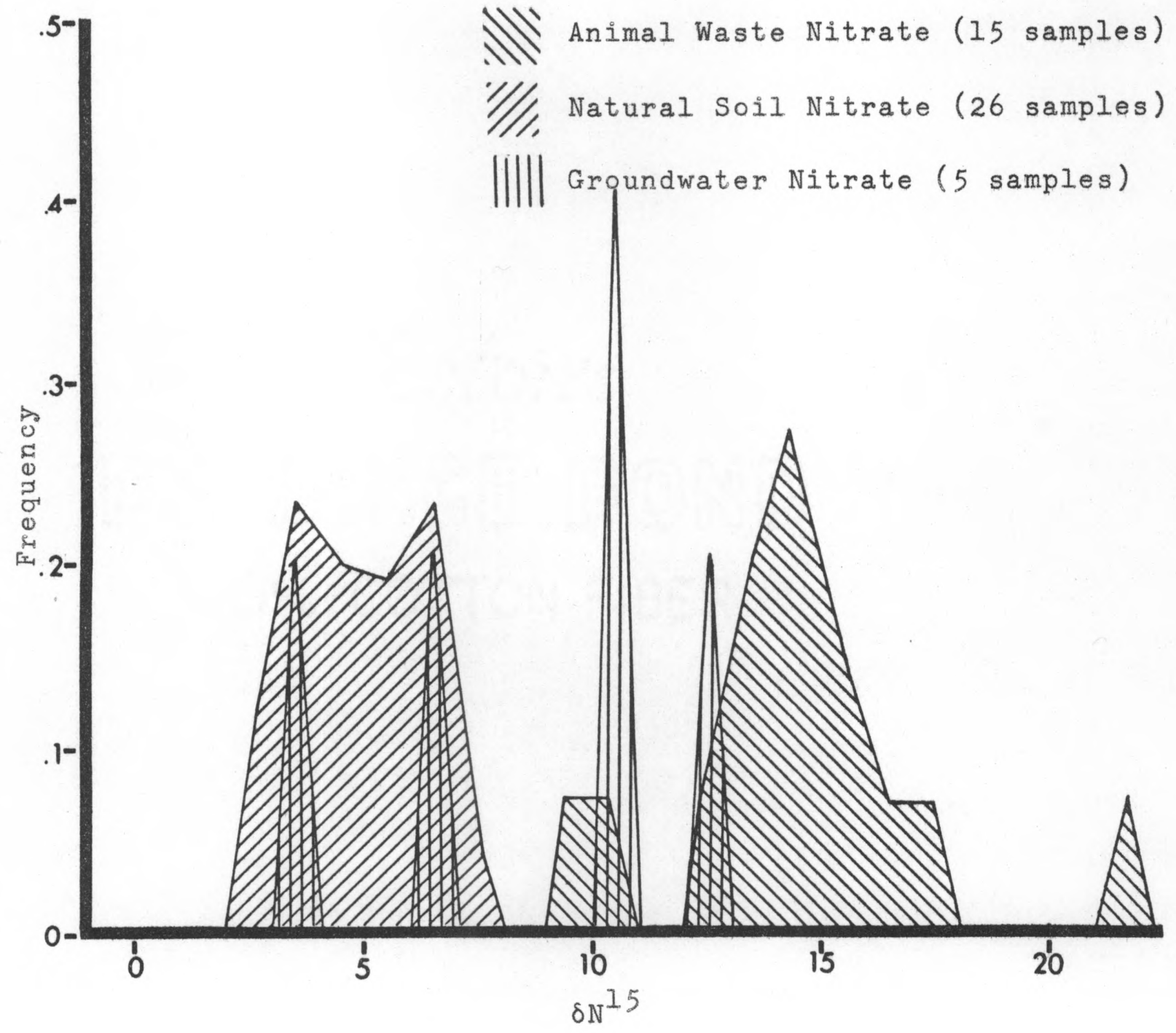

Figure 20。 $\delta N^{15}$ of nitrate in groundwater from barnyard wells compared to $\delta N^{15}$ of natural soil nitrate and animal waste nitrate (Runnels County, Texas). Frequency polygons have a class interval of one $\delta N^{15}$ unit. Cumulative frequency of each curve is equal to 1.0 。 
illustrate this point. The farmhouse-barnyard complex is at the top of a slight hill and the direction of groundwater movement should be downslope. The soil and water samples from the barnyard are enriched in $\delta N^{15}$. A water sample from a well downslope from the barnyard-farmhouse complex is also enriched in $\delta N^{15}$. On the southeast side of the hill the shallow water table intersects the land surface forming a seep where continual evaporation of groundwater precipitates isotopically heavy nitrate. Movement of nitrate is away from the barnyard, and toward the field because of its topographic position.

The two barnyard water samples (numbers 15 and 18) with low $\delta \mathrm{N}^{15}$ values are on slopes. Water wells would be pumping, in part, groundwaters that had been recharged upslope. Therefore, barnyard wells could be pumping groundwaters with natural soil nitrate rather than groundwaters with animal waste nitrate.

The $\delta N^{15}$ of groundwater nitrate from wells in barnyards may be related to how often a well is pumped. If a well is not pumped frequently, the major nitrate source may be animal wastes. Frequently pumped wells will create cones of depression and draw groundwater from a more extensive area than just beneath the barnyard. Much of the nitrate in these groundwaters may be from natural soil nitrogen. Of the three high $\delta N^{15}$ samples, the wells that pumped water samples 388 
and 1034 had been used infrequently over a period of one year. However, the well that pumped sample 867 is actively used. The samples with lower $\delta \mathrm{N}^{15}$ values, 15 and 18 , were from wells that are pumped daily.

The $\delta \mathrm{N}^{15}$ of the nitrate from water wells in farmhouse complexes ( $f i g .19$ ) indicates some mixing of the two nitrate sources. This mixing is further documented by two samples collected from well 551, listed in Appendix 2(p. 128) as 551 and 551a. Sample 551 was collected from the normal producing horizon of 90 feet $(10.9 \mathrm{~m})$ whereas sample 551 a was collected from a seep draining into the well at a depth of 16 feet ( 4.9 $m)$. According to the owner of the well, the seep was a veritable waterfall during the rainy season. The nitrates with higher $\delta N^{15}$ from the seep are mixing with the nitrates with lower $\delta N^{15}$ deeper in the well.

Causes of high nitrates.--Figures 18, 19, and 20 (p. 95-97) demonstrate that the $\delta N^{15}$ of the groundwater nitrate can be used to identify sources of $\mathrm{NO}_{3}$ in southern Runnels County, Texas. The two sources are natural soil nitrogen, the predominant source, and animal waste nitrogen. The relative contribution of each source can be calculated by making certain assumptions and by comparing the ratio of acreage for different land uses. The assumptions are: (1) twenty percent of the groundwater nitrate beneath farm complexes originates from animal waste material, whereas eighty percent 
originates from natural soil nitrogen; (2) the volume of groundwater per unit area is the same under farmhouse-barnyard complexes as under cultivated fields; (3) the nitrate concentrations in the groundwater are relatively constant under both conditions; (4) the total area of the farm is 400 acres and the farmhouse-barnyard complex occupies two acres. The acreage producing nitrate from natural soil nitrogen is 200 times greater than the acreage producing nitrate from animal wastes, and only twenty percent of nitrate in the groundwaters beneath the farmhouse-barnyard complexes is from animal wastes. The estimated contribution of nitrate from soil nitrogen is then 1,000 times greater than the nitrate contribution of animal wastes.

The conclusion that the oxidation of soil humus by cultivation can be a major source of nitrate in groundwater is startling and has received little acceptance in the literature. Only Stout and Burau (1967) and Stanford et al. (1970) considered organic soil as an important source of nitrogen. To use this model of nitrate contamination for southern Runnels County, three additional problems must be considered. (1) Was there enough organic nitrogen in the original soils to account for the nitrates in the groundwater? (2) When was the organic nitrogen oxidized to nitrate? (3) When was the nitrate leached below the root zone and then leached into the groundwater? 
The total nitrogen content of a noncultivated soil depends on soil type, type of vegetation on the soil, soil texture and rainfall regime. Schriener and Brown (1938) found that different soil types had different total nitrogen concentrations (table 18). Chernozem soils and Prairie soils have high concentrations, whereas soils in progressively wetter or drier climates have progressively lower concentrations of nitrogen. In the wet climates the soil organic matter is rapidly mineralized and leached. In the desert climates there is inadequate plant growth to develop much soil organic matter. The semiarid climate ( 20 to 25 inches ( 510 to $640 \mathrm{~mm}$ ) of rain per year) provides a happy medium between increased plant growth and minimal decomposition and leaching. The soils in Runnels County, Texas, are Chestnut soils which form under average rain of 14 to 24 inches ( 360 to $610 \mathrm{~mm}$ ) (Millar, et al., 1958). Oxidizing 50\% of the nitrogen in these soils would create nitrate concentrations of at least $500 \mathrm{mg} / \mathrm{kg}$. Before 1900 Runnels County, Texas, was covered with buffalo grass, which favored a high nitrogen content in the soils. Soils under grasslands develop higher nitrogen concentrations than similar soils beneath forests. As annual grasses die, their roots are rapidly added to the soil humus, whereas in forests, the root systems do not decay annually, nor do they occupy such a large fraction of the soils volume as the grass roots (Villenski, 1957). 
Table 18. Average nitrogen content in various soils of the United States (from Schriener and Brown, 1938)

\begin{tabular}{|c|c|c|c|}
\hline \multirow[b]{2}{*}{ Soil Type } & \multicolumn{2}{|c|}{ Nitrogen, percent } & \multirow[b]{2}{*}{$\begin{array}{l}\text { Pounds }(\mathrm{kg}) \text { of } \\
\mathrm{N} \text { per acre to } \\
\text { a depth of } 1 \mathrm{~m}\end{array}$} \\
\hline & $\begin{array}{l}\text { Surface } \\
15.2 \mathrm{~cm}\end{array}$ & $\begin{array}{l}\text { Average } \\
\text { to depth } \\
\text { of } 1 \mathrm{~m}\end{array}$ & \\
\hline Brown Forest & $0.05-0.20$ & 0.05 & $(3,040)$ \\
\hline Red and Yellow & $0.05-0.15$ & 0.03 & $(1,820)$ \\
\hline Prairie & $0.10-0.25$ & 0.12 & 16,000 \\
\hline Chernozem & $0.15-0.30$ & 0.12 & 16,000 \\
\hline Chestnut & $0.10-0.20$ & 0.08 & 10,700 \\
\hline Brown & $0.10-0.15$ & 0.06 & $(3,630)$ \\
\hline
\end{tabular}


The nitrogen content also is related to the clay content. Soils with high clay content can have much higher nitrogen contents. This is reflected in the nitrogen contents of several New York soils (fig. 2l). The texture of the soil in Runnels County is typically clay loam or silty clay loam.

No analyses for total nitrogen in any of the soils were made to confirm original high concentrations. All highly productive soils are now under cultivation and, thus, the total nitrogen would be lower than in the original soils. Likewise, no analyses for total nitrogen of noncultivated soils were made because most noncultivated soils in southern Runnels County are unproductive and would be expected to have lower total nitrogen contents than the productive soils. The few "good" noncultivated soils have unique land use, such as cemeteries or railroad right-of-ways, and present inherent sampling problems.

The oxidation of soil nitrogen has been occurring since the first days of cultivation. After 1900 there was a steady immigration of East European farmers to southern Runnels County. The population peaked around 1925 with 27,850 inhabitants living on approximately 2500 farms (Texas Almanac, 1973). In the southern part of the county the farmers put nearly every acre into crop production. The air photos in Soils of Runnels County, Texas (Wiedenfeld et al,, 1970) show this extensive cultivation. The high nitrate concentrations 


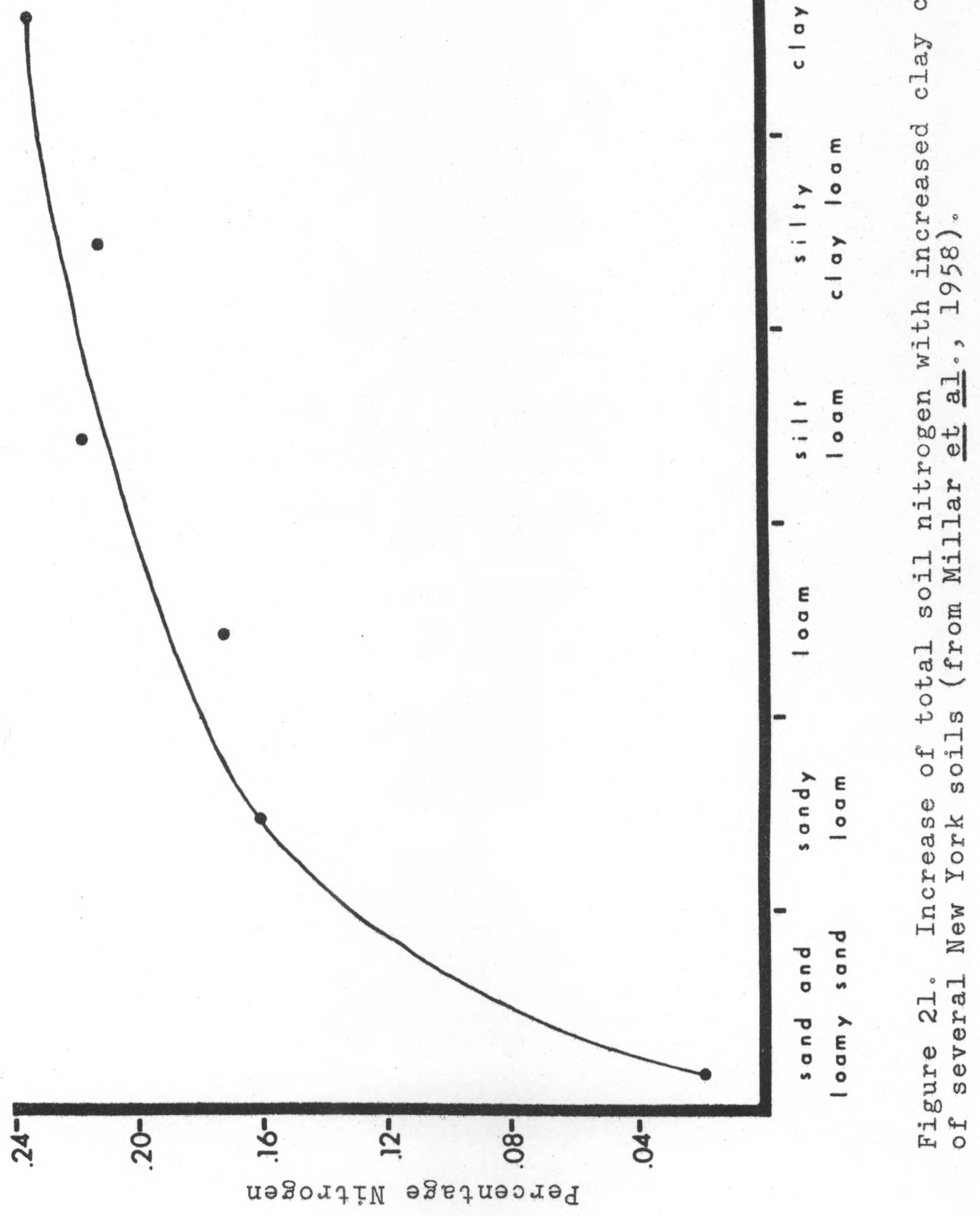


of the turnroad soils (figs. 11 ( .43$)$ and 12 (p. 44) are the result of the oxidation of natural soil nitrogen and the lack of nitrogen assimilation by plants. The high nitrate concentrations of these profiles are consistent with the amount of nitrate that can be oxidized from the organic nitrogen in a Chestnut soil.

Determining when the nitrates were leached below the root zone and into the groundwater is a more difficult problem. Table 12 ( $p .73$ ) shows that nitrate at shallow depths in cropland soils will be taken up by plant roots; thus, for nitrate to be a potential groundwater contaminant, it first must be leached below the root zone and then leached to the water table.

Nitrate has been accumulating below the root zone since 1900. The winter fallow season permits both the generation and the leaching of nitrate. The amount of winter rains has been adequate to leach nitrate below the root zone. In the mid 1950's there was extensive terracing of the fields to improve retention of soil moisture. According to many of the farmers, the water table rose appreciably, more than 20 feet in some places. The increased infiltration of water and the groundwater, which rose to near the ground surface, leached the nitrates from the vadose zone into the groundwater.

Tritium analyses indicate that the nitrates were leached into the groundwater after the drought of the early 
$1950^{\prime} \mathrm{s}$. Using the tritium dating techniques of Dincer and Davis (1968), groundwaters from wells 1003, 552, and the City of Miles were dated at 13 to 17 years old, 8 to 13 years old, and 9 to 12 years old respectively, relative to 1974. These samples, which represent the deepest groundwaters in the area, are all post-terracing, thus the leaching also appears to be post-terracing. A detailed discussion of the groundwater agedating techniques is in Appendix 5 (p. 132).

The nitrates in the groundwaters of southern Runnels County are the result of the oxidation of part of the humus of semiarid grassland soils and the subsequent leaching of the nitrate to the saturated zone by extensive terracing in the $1950^{\prime} \mathrm{s}$. This conclusion is disturbing because there are no inexpensive measures which would alleviate the problem. However, most of the nitrate may have been leached away by the rising groundwater. Analyses of groundwaters over a three year period show an apparent gradual decrease in the nitrate concentration (Appendix 2, p. 128). Even if this trend continues, it will be many years before the nitrate concentrations are reduced to U.S.P.H.S, recommended limit of $45 \mathrm{mg} / \mathrm{l}$.

\section{Macon County, Missouri}

To further test the use of $\delta \mathrm{N}^{15}$ for tracing nitrate in groundwater, I collected groundwater samples from a locality where the major source of nitrate was animal waste and not 
natural soil nitrogen. The area chosen was Macon County, Missouri, because Smith (1969) believed that many of the high nitrate groundwaters in the glacial drifts of northern Missouri were the result of animal waste contamination. More than $50 \%$ of the wells sampled in Macon County have water with nitrate concentrations above $20 \mathrm{mg} / \mathrm{I} \mathrm{NO}_{3}$ (Smith, 1969).

Hydrogeology.--Macon County is covered by glacial drift of Kansan and Nebraskan age. Maximum thickness is approximately 175 feet $(63.5 \mathrm{~m})$. The drift is a heterogeneous mixture of blue-gray clay, sand, and some gravel and boulders. The upper nondissected surface forms a relatively level plain. The major streams cut through the drift to the underlying Pennsylvanian strata (Gentile, 1967).

Groundwater supplies are obtained from shallow wells in the Pleistocene glacial drift and Recent terrace gravels along the larger streams (Gentile, 1967). Wells are typically shallow, hand dug, poorly cased, and have low yields. Many of these wells are a century old and are invariably near houses or livestock feeding areas. Groundwater from one dug well 30 feet $(10.9 \mathrm{~m})$ deep had a nitrate concentration of 745 $\mathrm{mg} / 1$. A deserted barnyard was close to the well (Smith, 1969). Water from the deep wells in Paleozoic formations is highly mineralized and thus is rarely used (Gentile, 1967).

Land-use practice.--Land use is $40 \%$ cultivated cropland, 50\% pasture, and 10\% woods (Kerr, Gerald, personal 
communication, August 1973). This contrasts with southern Runnels County, Texas, where approximately $90 \%$ of the land is cultivated. Rainfall in Macon County averages 37 inches ( 940 $\mathrm{mm}$ ) per year (Gentile, 1967). Ammonium nitrate is the nitrogen fertilizer most commonly used. The usual rate of application is between 200 and 300 pounds (90 to $140 \mathrm{~kg}$ ) per acre per year. Little anhydrous ammonia or urea is used (Kerr, G., personal communication, August 1973). Nearly all water wells are in farmhouse-barnyard complexes.

\section{$\delta \mathrm{N}^{15}$ of nitrate in groundwater, --Eleven groundwater}

samples were collected with the help of Gerald Kerr, Area Local Government Specialist of the University of Missouri Cooperative Extension Service. All water samples are from handdug or drilled wells or from buried cisterns near active or deserted barnyards or farmhouses. Appendix 6 contains information on well owner, sampling location, nitrate concentration of the water and $\delta \mathrm{N}^{15}$ of the $\mathrm{NO}_{3}$. Plate 3 shows the locations of the water wells.

Figure 22 shows the relationship of nitrate concentration to $\delta N^{15}$ values of the eleven samples (circles). The nitrate concentrations range from $60 \mathrm{mg} / \mathrm{l}$ to $330 \mathrm{mg} / \mathrm{l}$. The $\delta \mathrm{N}^{15}$ values range from $+100 \%$ to $+19 \%$. The low correlation coefficient $(r=-0.11)$ indicates no correlation between $\mathrm{NO}_{3}$ concentrations and $\delta \mathrm{N}^{15}$ values. An overlay of the frequency distribution of $\delta \mathrm{N}^{15}$ in Macon County groundwater nitrate on 


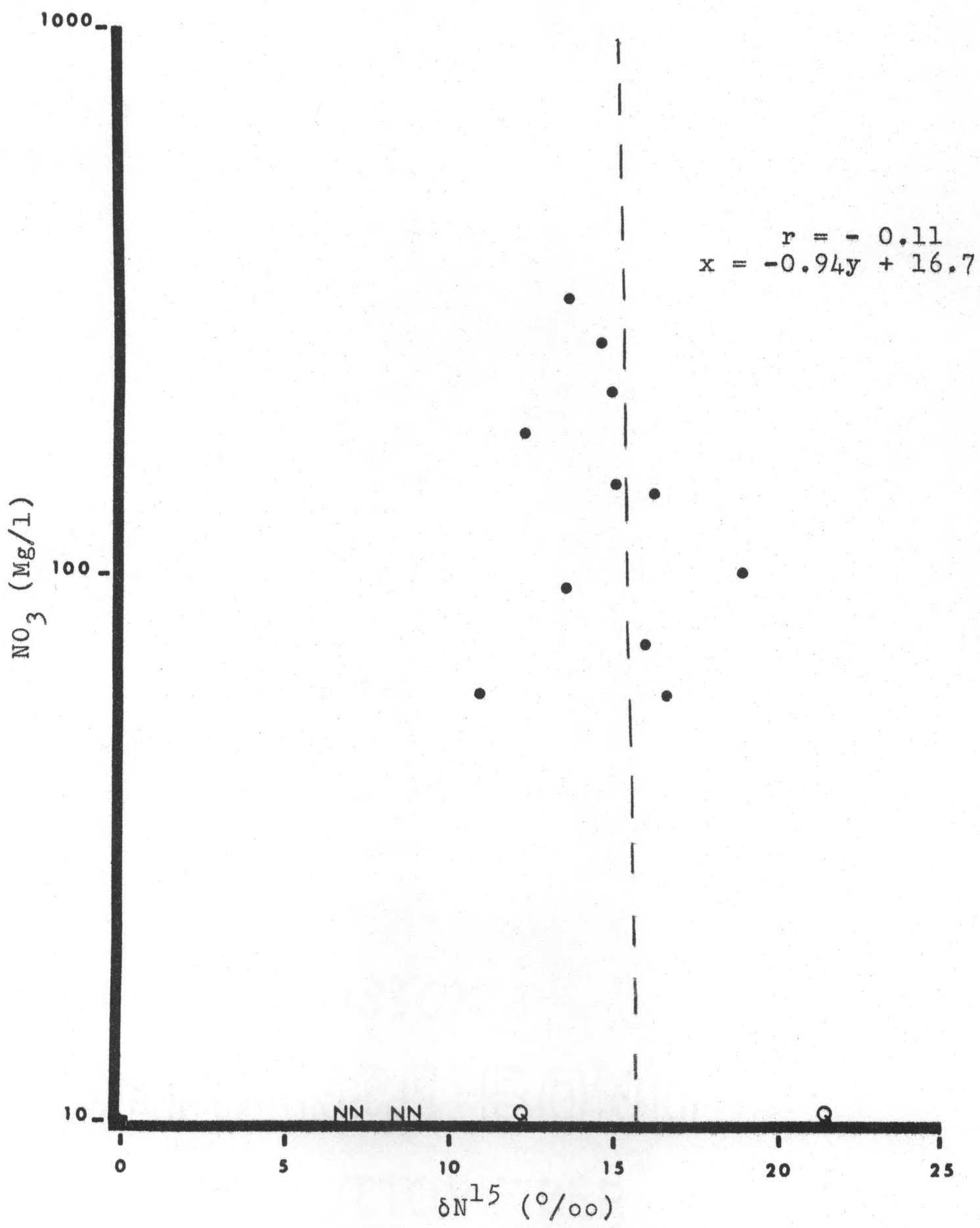

Figure 22. $\delta N^{15}$ of groundwaters from Macon County, Missouri, and $\delta \mathrm{N}^{15}$ of groundwaters from Long Island, New York. 
the two isotopic ranges of soil nitrate from Runnels County shows a very good correlation between animal waste nitrate and the groundwater nitrate of Macon County (fig. 23). This should be expected because Macon County is not as extensively cultivated as southern Runnels County. Natural soil nitrogen is greatly diminished as a nitrate source. With rates of groundwater movement probably less than a few feet per year, nitrates could not have migrated far from their source. All the wells sampled are near farmhouses or barnyards, thus the logical source is animal waste nitrate. The $6 N^{15}$ of these nitrates and the $\delta \mathrm{N}^{15}$ of artificial fertilizers are not in the same range. Fertilizer, therefore, is not considered to be a source of the nitrate in the waters sampled.

The high similarity of the $\delta \mathrm{N}^{15}$ of the nitrate in groundwaters from Macon County and the $\delta \mathrm{N}^{15}$ of animal waste nitrate supports a number of conclusions. (1) The nitrate in Macon County groundwaters is of animal waste origin. This confirms Smith's (1969) hypothesis. (2) The $\delta N^{15}$ values show the effectiveness of animal waste nitrate in contaminating groundwater supplies in certain cases. (3) The $\delta N^{15}$ techniques can be used to trace animal waste nitrate as well as natural soil nitrate. (4) Finally, the chemical reactions controlling the $\delta \mathrm{N}^{15}$ of animal waste nitrate are effective in geographic localities other than southern Runnels County, Texas. Differing climate, soil, and geology apparently do 


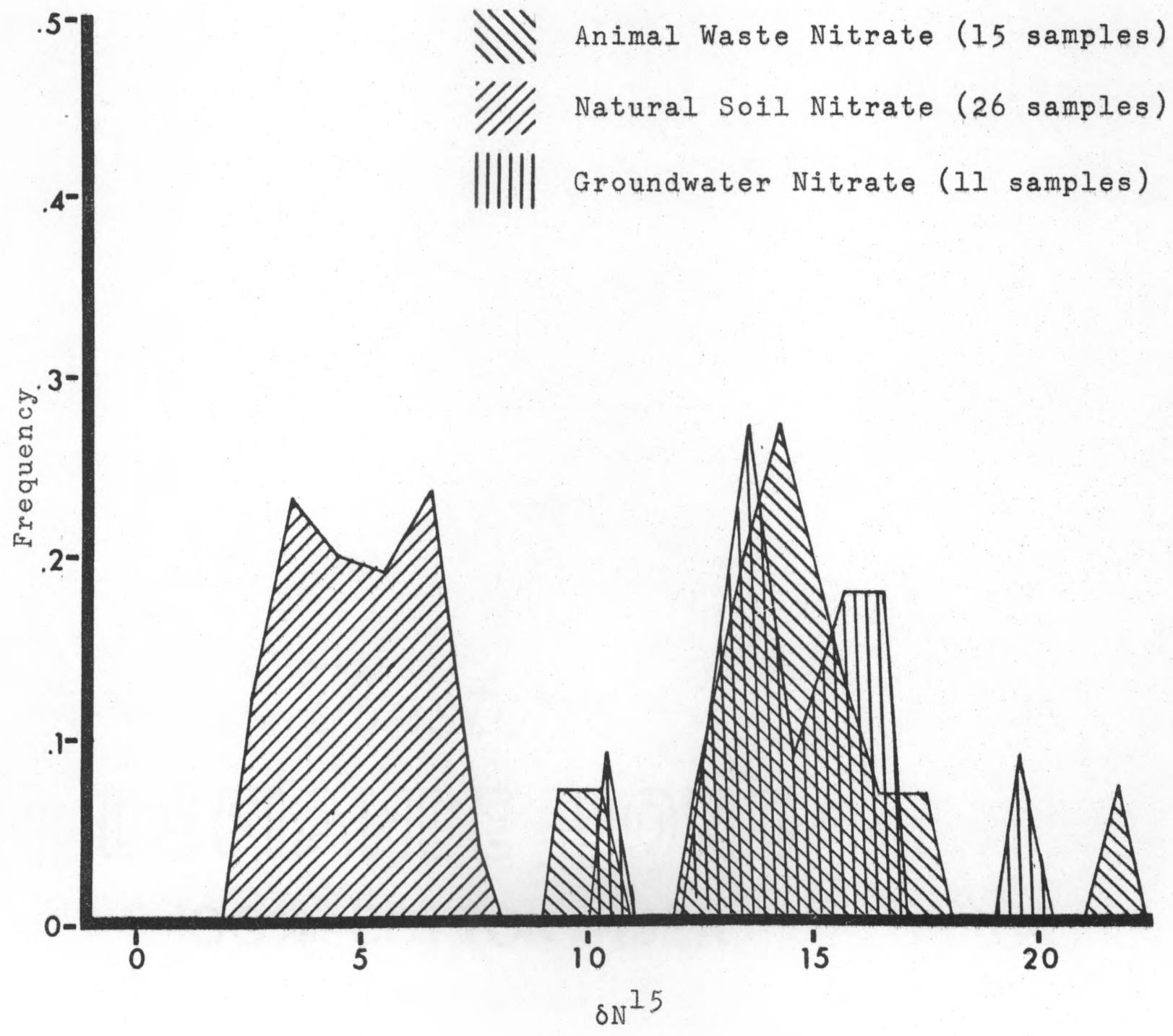

Figure 23. $\delta N^{15}$ of nitrate in groundwater from Macon County, Missouri, compared to the $\delta N^{15}$ ranges of natural soil nitrate and animal waste nitrate from Runnels County, Texas. Frequency polygons have a class interval of one $\delta N^{15}$ unit. Cumulative frequency of each curve is equal to 1.0 . 
not alter the isotope geochemistry of nitrogen.

\section{Long Island, New York}

Kimmel (1972) concluded that the high nitrates in groundwaters of Kings County, Long Island, New York, were the result of leaking sewers contaminating the Upper Glacial aquifer. Kings County, therefore, seemed a good locale to further test nitrogen isotope techniques, but with a different source of nitrogen, sewage, and a different geographic area, northeastern U.S.A. Upon arrival in Mineola, I found it nearly impossible to collect water samples for both technical and safety reasons. The water wells sampled by Kimmel (1972) were located beneath heavy machinery in a foundry, in a zipper factory, between railroad ties in a switching terminal, in a warehouse, in the bathroom of a pornographic movie theater, and in the basement of a "strip joint." The wells were all very old, dating from the early $1900^{\prime} \mathrm{s}$, and were welded shut with small diameter openings for limited access. However, Kimmel (1972) did not mention these sampling problems.

I decided not to sample groundwater in Kings County, but instead to collect groundwaters in Queens and Nassau Counties, Long Island, New York, because both counties had high nitrate and sampling was much safer. The source of nitrate in Queens County is similar to the probable source in Kings County, old septic tanks and leaking sewer lines 
(Braids, 0., personal communication, August 1973). The dominant sources of nitrate in Nassau County are septic tank effluent and agricultural sources--both artificial fertilizer and natural soil nitrogen.

Hydrogeology.--The Pleistocene and Cretaceous sediments on Long Island can be divided into six major hydrogeologic units (table 19). Groundwater recharge is derived locally from precipitation. Recharge to the Magothy, Jameco, and Lloyd aquifers is by downward flow from the Upper Glacial aquifer (fig. 24).

Land-use practice.--Kings County and Queens County have similar histories of development because of their close proximities to the island of Manhattan (Braids, 0., personal communication, August 1973). Information on Queens County is limited because no published or open-file reports are available. I assume that development was similar to that of Kings County but slightly later because it is farther from New York City. These urbanized counties have had no agricultural activity and few septic tanks for several years. Kings County, and probably Queens County as well, is underlain by a dense network of sanitary and storm sewers. In Kings County, sewerage began about 1850. There were about 800 miles (1,280 $\mathrm{km}$ ) of sewer lines in 1908, 1,300 miles (2,080 km) in 1932, and 1,700 miles $(2,720 \mathrm{~km})$ in 1962. Leakage from these sewer lines is not only the major source of nitrate in the Upper 


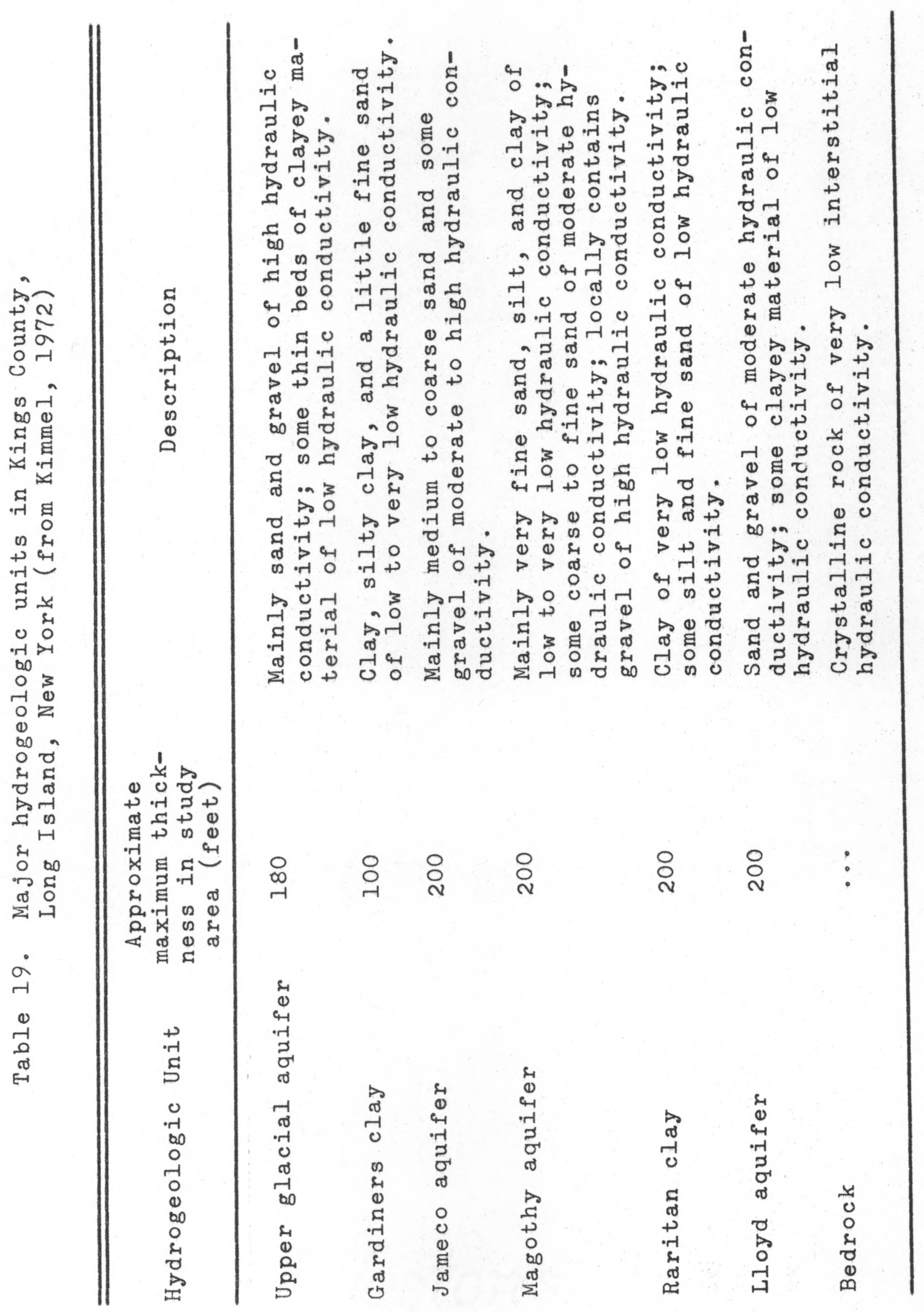




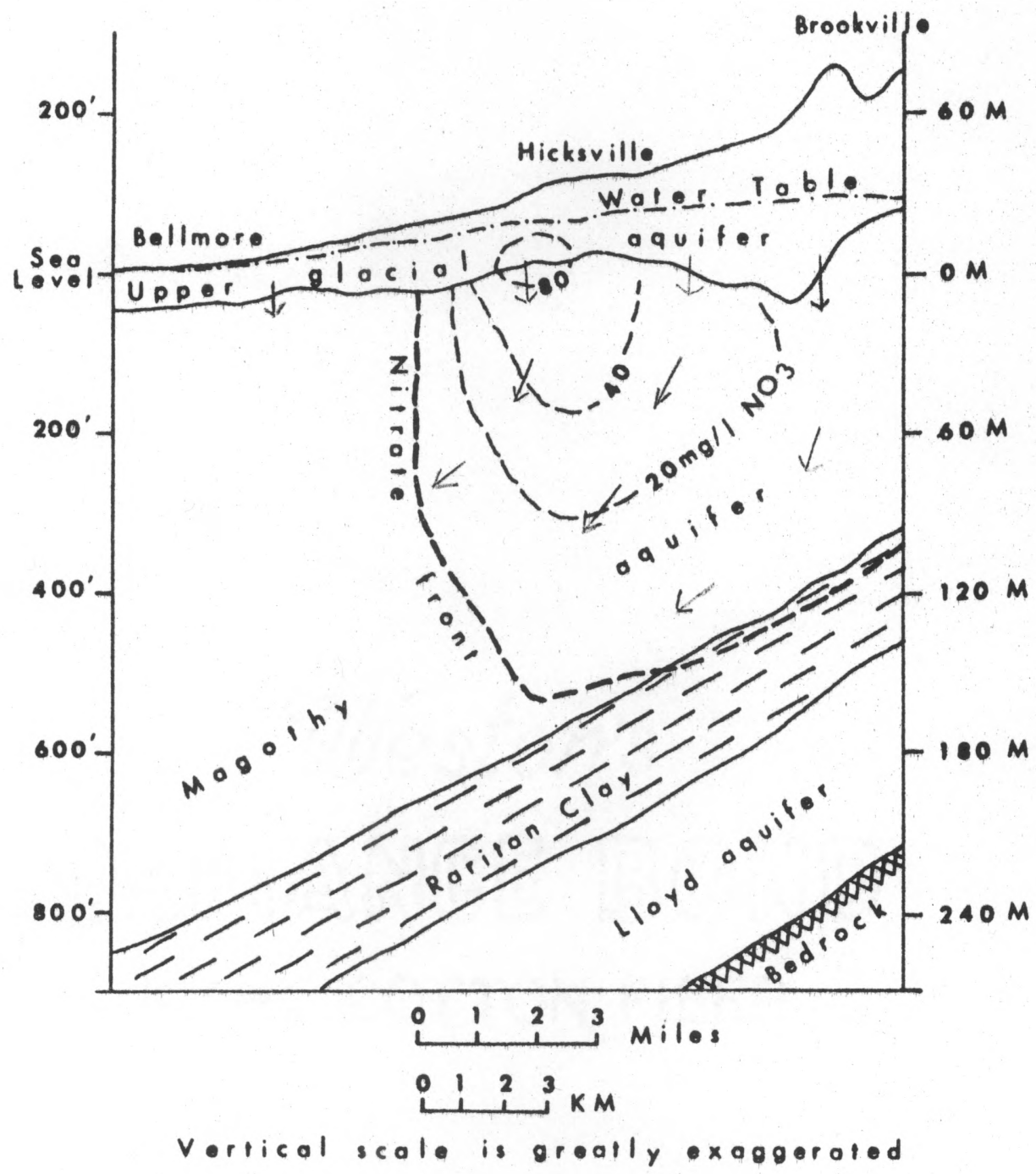

Figure 24. Recharge to Magothy aquifer (from Perlmutter and Koch, 1972). 
Glacial aquifer, but may also be the major source of recharge to the aquifer (Kimmel, 1972).

The numerous towns in Nassau County depend on the Upper Glacial, the Magothy, and to a small degree, the Lloyd aquifers for their municipal water supplies. The high nitrate concentration in the Upper Glacial and the Magothy are of great concern because of the public health hazard of using these waters for municipal supplies. Groundwater from the Lloyd aquifer is not a problem because of its low nitrate concentration (Harr, 1971). Each municipality pumps a number of wells. The town of Garden City pumps four wells and mix the waters from these wells to provide drinking water with a nitrate concentration below the recommended limit of $45 \mathrm{mg} / \mathrm{I}$. The nitrate in these aquifers is either from animal waste nitrogen (septic tanks and sewer lines) or from cultivation (from the oxidation of the soil humus or from the excessive use of nitrogen fertilizers). Nitrate contamination of the Upper Glacial aquifer by septic tanks has been documented by the Nassau-Suffolk Research Task Group (1969). This does not rule out nitrate generated from cultivation as a source, however. Farming began in colonial times and continued to the $1950^{\prime} \mathrm{s}$. There was heavy fertilizer use from the 1920's to the 1950's (Perlmutter and Koch, 1972). After World War II the land was gradually converted for residential construction. High-nitrate waters have migrated through the Upper 
Glacial aquifer and deep into the Magothy aquifer. Figure 24 shows the nitrate front in the Magothy aquifer. Because there is an average rate of vertical movement of ten feet per year, the nitrates in the Magothy aquifer probably were added to the groundwater in the early days of heavy fertilizer usage and extensive cultivation in the $1920^{\prime} \mathrm{s}$. This would imply that the fertilizer and expanded cultivation from the 1920's to preresidential days of the $1940^{\prime} \mathrm{s}$ is the cause of the high nitrate concentration. Another parameter which may control the nitrate front is the reduction of the nitrate to ammonium. The reduction of nitrate is implied by the downgradient loss of dissolved oxygen (Perlmutter and Koch, 1972).

\section{$\delta N^{15}$ of nitrate in groundwater.--Six samples were col-} lected from the two county area. In Queens County, two samples were from the Upper Glacial aquifer, one from a shallow well next to the Maryland Pavilion at the deserted site of the New York Worlds Fair $\left(\delta N^{15}=+12.1 \% \circ\right)$, the second from a well at the intersection of the Southern Parkway and the Rockway Parkway $\left(\delta N^{15}=+21.3 \% / 00\right)$ (table 20 and fig. 22, p. 109).

In Nassau County, four samples were collected from municipal water districts pumping from the Magothy aquifer. The four municipal water districts are Hicksville, Garden City, Westbury, and Eisenhower Park (table 2l). Because of circumstances beyond my control, I could not take water samples at the well. Therefore, the samples were collected from 
Table 20. $\delta \mathrm{N}^{15}$ of nitrate in groundwater from Long Island, New York

\begin{tabular}{|c|c|c|c|}
\hline $\begin{array}{l}\text { Well } \\
\text { Number }\end{array}$ & Location & $\begin{array}{c}\mathrm{NO}_{3} \\
(\mathrm{mg} / \mathrm{l})\end{array}$ & $\begin{array}{c}8 N^{15} \\
(0 / 00)\end{array}$ \\
\hline
\end{tabular}

\section{Queens County}

Q 2993

Intersection of Southern

20

$+21.3$

Parkway and Rockway Parkway

Q 2417

Maryland Pavilion, New York City Worlds Fair Grounds

Nassau County

$\begin{array}{lll}\text { Hicksville (Texaco Station) } & 15 & +9.0 \\ \begin{array}{l}\text { Westbury (Mobil Station, } \\ \text { Post Avenue) }\end{array} & 17 & +6.8 \\ \begin{array}{l}\text { Eisenhower Park (drinking } \\ \text { fountain in Eisenhower }\end{array} & 25 & +7.0 \\ \begin{array}{l}\text { Park) } \\ \text { Garden City (U.S.G.S., } \\ \text { drinking fountain in Federal }\end{array} & 15 & +8.6 \\ \text { Building) }\end{array}$




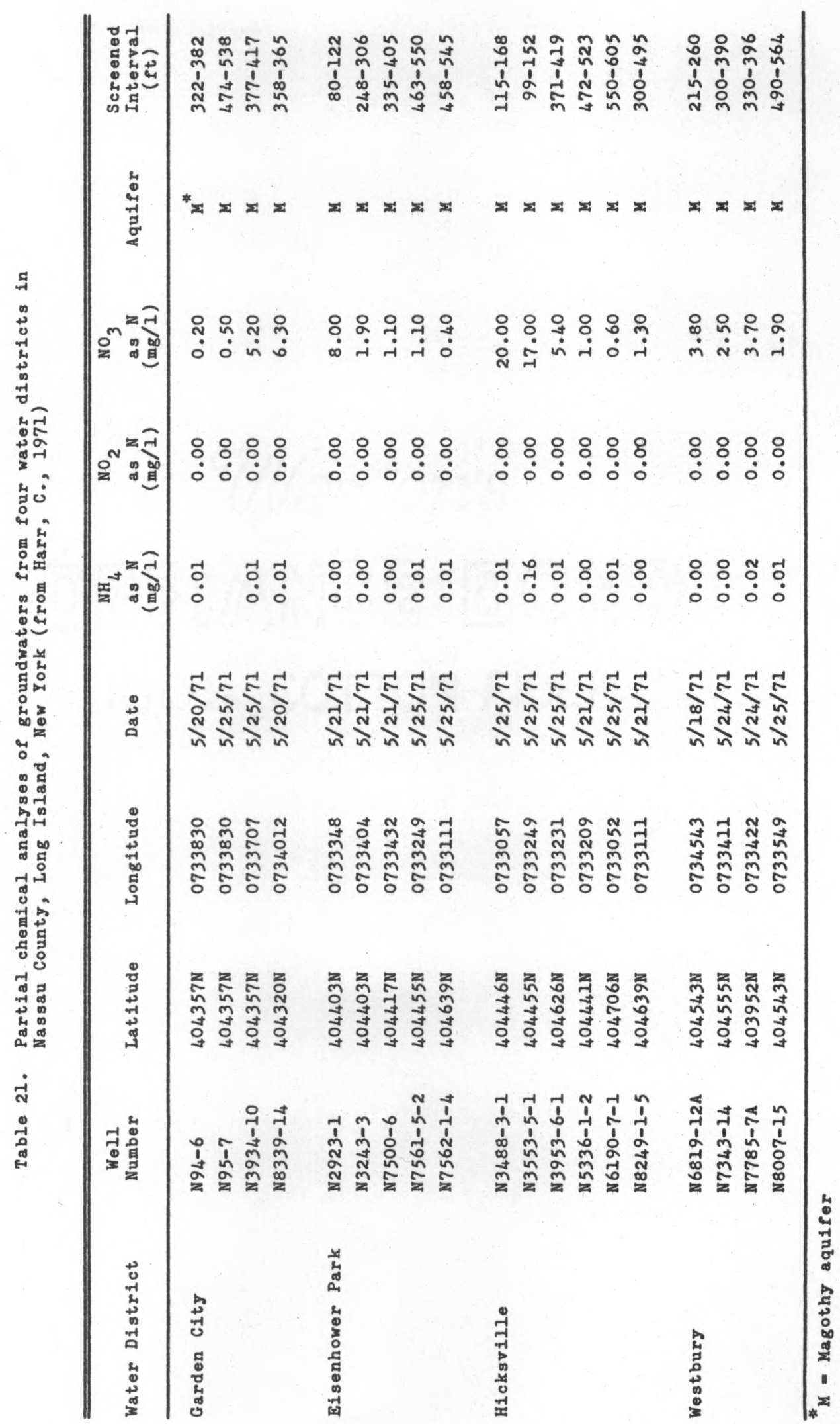


randomly chosen water faucets in the four districts. In Hicksville a sample was collected at a Texaco station; in Westbury at a Mobil station; in Eisenhower Park at a public drinking fountain; and in Mineola from a drinking fountain in the U. S. Geological Survey Office in the Federal Building which is in the town of Mineola, but in the water district of Garden City. The water samples from the faucets are assumed to be from different wells which are mixed in the distribution system. The $\delta N^{15}$ values represent averages for particular well districts. Groundwater nitrate from Hicksville had a $\delta N^{15}$ of $+9.00 \% 00$; groundwater nitrate from Westbury had a $\delta N^{15}$ of $+6.8 \% 0$; groundwater nitrate from Eisenhower Park had a $\delta N^{15}$ of $+7.0 \%$; and groundwater nitrate from Garden City had a $\delta N^{15}$ of $+8.6 \%$ (table 20 (p. 118) and fig. 22 (p. 109)).

Figure 22 (p. 109) shows that all the samples from Nassau County are isotopically lighter than the Queens County samples. They are slightly heavier than the natural soil nitrates from southern Runnels County, Texas, and appreciably lighter than the average $\delta N^{15}$ value of animal waste nitrate from southern Runnels County. The $\delta N^{15}$ 's of the Nassau County samples were also lighter than the average $\delta N^{15}$ of groundwater nitrate from Macon County, Missouri. The origin of most of the groundwater nitrate in Nassau County appears to be either organic nitrogen of soil humus or nitrogen 
fertilizer. Animal waste is not the dominant source.

The $\delta N^{15}$ values of the groundwater nitrates in Queens County are higher than the $\delta N^{15}$ of the groundwater nitrates from Nassau County, falling in the range of animal waste nitrate, which would support the leaky sewer hypothesis.

The data presented in this dissertation do not fully prove the source of nitrate in the aquifers of Long Island, but do suggest that some of the sources previously considered by Kimmel (1972) and Perlmutter and Koch (1972) are plausible. Additional analyses of the $\delta \mathrm{N}^{15}$ of groundwater nitrate would be needed to establish a more definite conclusion. 
CONCLUSIONS

(1) Nitrogen isotope ratios of ammonium and nitrate ions from soil and water samples can be analyzed reproducibly with an experimental error of $\pm 1 \% / 00$.

(2) Slight variations from the procedures of analysis can cause isotopic fractionations. Techniques causing fractionations are the use of coarse-grained Devardas Alloy and the incubation of the soil organic nitrogen after collection and before analysis of the sample.

(3) There are two isotopic ranges of soil nitrate in southern Runnels County, Texas. Nitrate derived from the decomposition of animal waste nitrogen yields a $\delta N^{15}$ of $+100 / 00$ to $+22 \% 00$. Nitrate derived from the mineralization of organic nitrogen in soil humus has a $\delta N^{15}$ of $+20 / 00$ to $+80 / 00$.

(4) Isotope ratio of animal waste nitrate is controlled in part by the volatilization of isotopically light ammonia gas during the decomposition of urea in urine. Isotopic fractionation may occur within an animal.

(5) Isotope ratio of natural soil nitrate appears to be controlled by the deamination of isotopically light protein material to ammonia and not the nitrification of ammonia to nitrate. Denitrification, ammonia volatilization, and ammonium adsorption do not appear to be controlling reactions for the $\delta N^{15}$ of natural soil nitrate. 
(6) Nitrogen in artificial fertilizer has a $\delta N^{15}$ range which overlaps the $\delta N^{15}$ range of natural soil nitrate. Nitrate from fertilizer will be difficult to differentiate from nitrate produced by the oxidation of soil nitrogen.

(7) In southern Runnels County, Texas, the major source of nitrate in the groundwater is natural soil nitrate. The $\delta N^{15}$ of the groundwater nitrate beneath cultivated fields corresponds well with $\delta \mathrm{N}^{15}$ of natural soil nitrate. Groundwater beneath farmhouse-barnyard complexes has a higher $\delta N^{15}$, indicating a contribution of animal waste nitrate. Groundwater from wells in barnyards has a wide range of $\delta \mathrm{N}^{15}$ values. (8) The nitrates in the groundwaters of southern Runnels County, Texas, are the result of cultivation which causes the oxidation of some of the organic nitrogen to nitrate. Natural soil nitrogen may contribute as much as 1,000 times more nitrate to the groundwater than animal wastes. Extensive terracing during the 1950's in southern Runnels County caused the water table to rise, allowing the groundwater to leach the soil nitrate into the aquifer system.

(9) Groundwaters from Macon County, Missouri, are contaminated with nitrate from animal wastes. There is a good correlation between the $\delta N^{15}$ range of groundwater nitrate from Macon County, Missouri, and the $\delta N^{15}$ range of animal waste nitrate from southern Runnels County, Texas. (10) The $\delta \mathrm{N}^{15}$ of nitrates from the Upper Glacial 
aquifer in Queens County, Long Island, New York, suggests that the source of nitrate is leaky sewer lines. The $\delta \mathrm{N}^{15}$ of groundwater nitrate from the Magothy aquifer in Nassau County, Long Island, New York, suggests that the source of the nitrate is either natural soil nitrogen or artificial fertilizer. Further research using nitrogen isotopes may positively identify the sources of groundwater nitrate in the Pleistocene and Cretaceous aquifers of Long Island.

(II) The identification of the source of groundwater nitrate in southern Runnels County, Texas, and Macon County, Missouri, indicate that the techniques developed in this study are applicable for identifying sources of nitrate in other polluted waters. 


\section{APPENDICES}


Appendix 1. Reagents Used in $\delta N^{15}$ Analysis

Magnesium Oxide.--Finely powdered reagent-grade $\mathrm{MgO}$ is used directly from the bottle. Bremner and Keeney (1966) recommended ignited magnesium oxide to remove any carbonate minerals. Distillation of MgO solutions with carbonate contamination can lead to liberation of $\mathrm{CO}_{2}$ which will interfere with the determination of ammonium by the titration method. This can be a problem for very low ammonium concentrations (in micrograms of $\mathrm{N}$ ). The concentration of all ammonium analyses of this study were greater than $1 \mathrm{mg}$ of $\mathrm{N}$, thus $\mathrm{CO}_{2}$ interference was not considered a problem.

$$
\text { Devardas Alloy.-- }(50 \% \mathrm{Cu}, 45 \% \mathrm{Al}, 5 \% \mathrm{Zn}) \text { Reagent- }
$$
grade alloy, less than $0.05 \% \mathrm{~N}$, is ground with a mortar and pestle until the product will pass a 100-mesh screen and at least $75 \%$ of it will pass a 200-mesh screen. As indicated in Chapter 1 , the fine-grained Devardas Alloy is absolutely necessary.

Sulfamic Acid.--Dissolve 2 grams of crystalline sulfamic acid in $100 \mathrm{ml}$ of water. Store this in a refrigerator. 0.I HCl Solution.--Prepare this from Baker reagentgrade $0.1 \mathrm{~N} \mathrm{HCl} \mathrm{Dilut-it.}$

O.I NaOH Solution.--Prepare this from Baker reagentgrade $0.1 \mathrm{~N} \mathrm{NaOH}$ Dilut-it. Hypobromite-iodide Solution.--Bremner (p. 1271, 1965) 
describes in detail the preparation of a hypobromite-iodide solution as follows:

Dissolve $200 \mathrm{~g}$ of $\mathrm{NaOH}$ in $300 \mathrm{ml}$ of water, and cool the solution in ice. Transfer half of the cooled solution to a 500-ml wide-mouth Erlenmeyer flask, immerse the flask in crushed ice, and add $60 \mathrm{ml}$ of $\mathrm{Br}_{2}$ over a period of 30 minutes. Stir the solution vigorously during addition of the $\mathrm{Br}_{2}$, and regulate the rate of addition so that the temperature of the solution does not exceed $5^{\circ} \mathrm{C}$. When the addition of $\mathrm{Br}_{2}$ has been completed, add the remainder of the $\mathrm{NaOH}$ solution; and, after stirring the mixture for a few minutes, stopper the flask, and place it in a refrigerator for 4 to 6 days. Remove the copious precipitate of $\mathrm{NaBr}$ which forms during this period of cold storage by filtration with suction through a glass-fibre filter, and dilute the filtrate with an equal volume of a solution prepared by dissolving $2 \mathrm{~g}$ of $\mathrm{KI}$ in 1 liter of water. Store the hypobromiteiodide solution in a tightly-stoppered bottle in a refrigerator. Take care during preparation and storage of the reagent to protect it from atmospheric $\mathrm{CO}_{2}$. One milliliter of this solution will oxidize 5 to 6 $\mathrm{mg}$ of $\mathrm{NH}_{4}$ to $\mathrm{N}_{2}$, and the reagent will retain its activity for at least 6 months if stored in a refrigerator. 


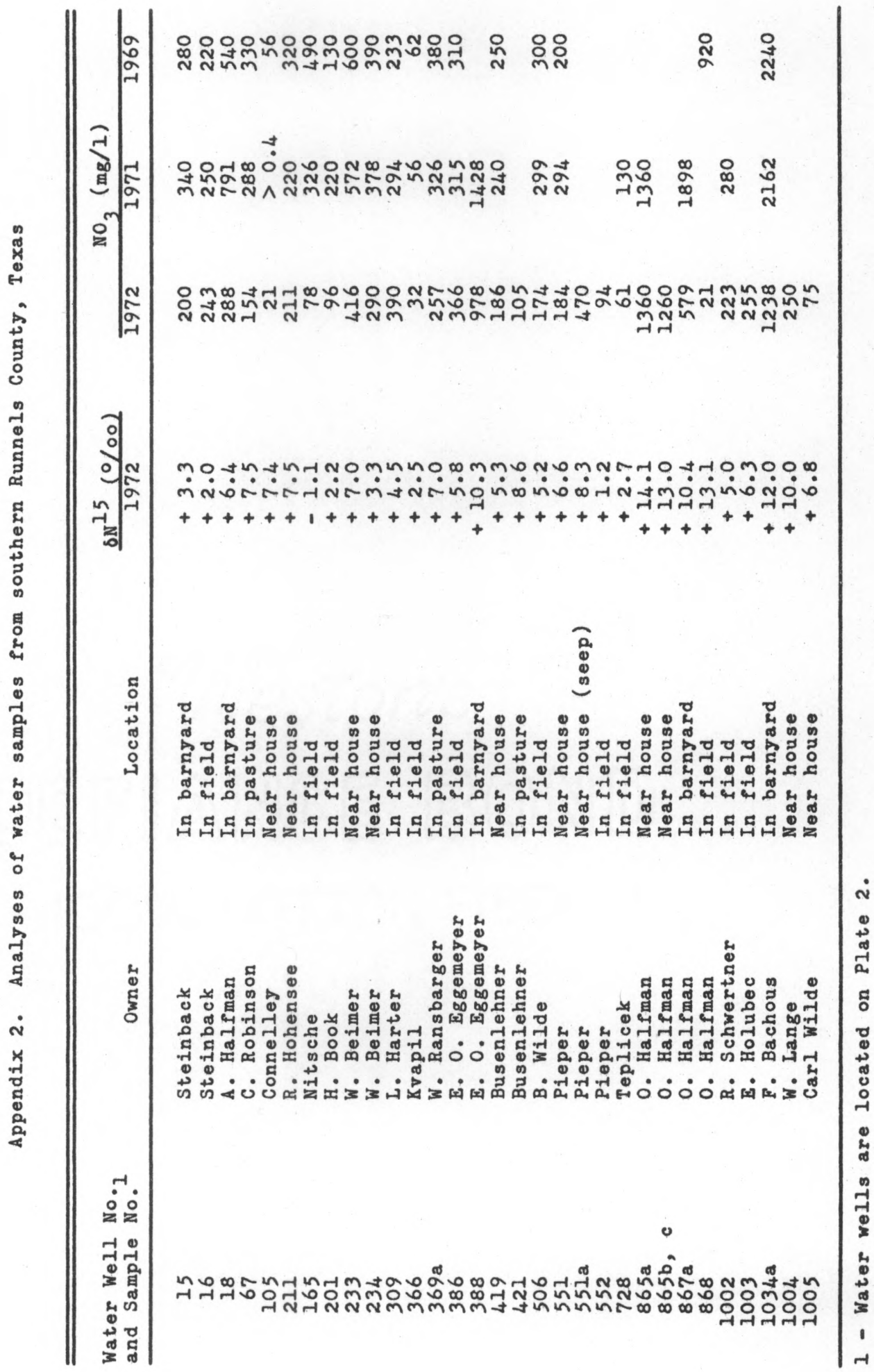


Appendix 3. Anslyses of solls from southern Runnels County, Texas

\begin{tabular}{|c|c|c|c|c|c|c|c|}
\hline $\begin{array}{l}\text { Sample } 1 \\
\text { Lecation } \\
\end{array}$ & $\begin{array}{l}\text { Depth } \\
\text { (ft) }\end{array}$ & Owner & Land $U_{80}$ & $\begin{array}{c}\mathrm{NO}_{3} \\
(\mathrm{mg} / \mathrm{kg})\end{array}$ & $\begin{array}{c}\mathrm{Cl} \\
(\mathrm{mg} / \mathrm{kg})\end{array}$ & $\begin{array}{l}8 N^{15} \\
(\% / 00)^{2}\end{array}$ & Soil Association ${ }^{3}$ \\
\hline \multirow[t]{7}{*}{ s } & 2 & Frank Gully & turnroad & 348 & & $4 \cdot 4$ & Rowena-Tobosa \\
\hline & 3 & & & 458 & & 3.8 & \\
\hline & 4 & & & 381 & & 4.5 & \\
\hline & 5 & & & 237 & & 3.6 & \\
\hline & 7 & & & 105 & & 2.7 & \\
\hline & 8 & & & 104 & & 2.0 & \\
\hline & 9 & & & 44 & & 2.5 & \\
\hline \multirow[t]{5}{*}{ b } & 1 & Paul Pleper & cornfield with cattle & $42 \cdot 5$ & & 15.3 & Rowena-Tobosa \\
\hline & 3 & & & 25 & & 17.9 & \\
\hline & 4 & & & 19 & & 11.8 & \\
\hline & 6 & & & 43 & & 11.6 & \\
\hline & $7+8$ & & & 32 & & 7.0 & \\
\hline \multirow[t]{4}{*}{ c } & 1 & Paul Pleper & cotton field & 43 & & 3.3 & Rowena-Tobosa \\
\hline & 3 & & & 65 & & 3.9 & \\
\hline & 5 & & & 75 & & 5.0 & \\
\hline & 7 & & & 104 & & 3.8 & \\
\hline \multirow[t]{6}{*}{ d } & 1 & Paul Pleper & barnyard & 180 & & 13.6 & Rowena-Tobosa \\
\hline & 3 & & & 1682 & & 16.5 & \\
\hline & 4 & & & 1300 & & 15.2 & \\
\hline & 5 & & & 429 & & 13.7 & \\
\hline & 6 & & & 706 & & 14.1 & \\
\hline & 10 & & & 700 & & 14.0 & \\
\hline \multirow[t]{3}{*}{ - } & 2 & Santa Fe Rallroad & right-of-way & 30 & 225 & 24.6 & Portales-Potter-Merota \\
\hline & 4 & & & 126 & 200 & 32.0 & \\
\hline & 7 & & & 36 & 45 & 19.2 & \\
\hline 8 & 2 & H. H. Gully & deserted barnyard & 135 & & 21.9 & Portales-Potter-Mereta \\
\hline \multirow[t]{2}{*}{ h } & $2+3$ & H. Н. Gully & cornfield & 10 & & 12.4 & Rowena-Tobosa \\
\hline & $4+5$ & & & 25 & & 7.8 & \\
\hline \multirow[t]{2}{*}{$j$} & 0 & Homer Eggemeyer & $\begin{array}{l}\text { barnyard soaked with } \\
\text { pig urine }\end{array}$ & & & 46 & \\
\hline & 3 & & barnyard & 805 & & 9.7 & Portales-Potter-Merota \\
\hline \multirow[t]{5}{*}{$\mathbf{k}$} & $1+2$ & Homer Eggemeyer & cotton fleld & 13 & & 5.8 & Portales-Potter-Mereta \\
\hline & $3+4$ & & & 36 & & 6.5 & \\
\hline & 6 & & & 58 & & 5.6 & \\
\hline & 7 & & & 49 & & 4.6 & \\
\hline & 8 & & & 45 & & 4.9 & \\
\hline \multirow[t]{3}{*}{1} & 1 & Emil Kvapil & cotton field & 78 & & $4 \cdot 4$ & Rowena-Tobosa \\
\hline & 3 & & & 36 & & 5.7 & \\
\hline & 5 & & & 32 & & 6.2 & \\
\hline m & 3 & Emil Krapil & barnyard & 1032 & & 14.0 & Rowens-Tobosa \\
\hline \multirow[t]{3}{*}{$\mathrm{n}$} & 1 & Walter Be1mer & cotton field & 37 & & 3.3 & Rowens-Tobosa \\
\hline & 3 & & & 32 & & 8.6 & \\
\hline & 5 & & & 19 & & 6.2 & \\
\hline \multirow[t]{4}{*}{$\circ$} & 2 & Walter Beimer & turnroad & 225 & & 6.7 & Rowena-Tobosa \\
\hline & 3 & & & 450 & & 5.7 & \\
\hline & 7 & & 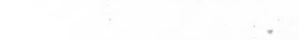 & 65 & & 6.4 & \\
\hline & 9 & & . & 70 & & 6.2 & \\
\hline \multirow[t]{2}{*}{$p$} & 2 & James Jones & oeptic tank drainfield & 33 & & 17.8 & Spur-Colorado-Miles \\
\hline & 3 & & & 33 & & 13.0 & \\
\hline 9 & 5 & James Teplicek & barnyard & 17 & & 15.9 & Rowena-Tobosa \\
\hline $\mathbf{r}$ & $6+7$ & Paul Busenlehner & pasture & 10 & & 10.4 & Portales-Potter-Merata \\
\hline $\mathbf{s}$ & 0 & Omar Halfman - & so11 seep & 631 & & 9.8 & Rowena-Tobosa \\
\hline t & 3 & Omar Halfman & barnyard & 306 & & 14.6 & Rowena-Tobosa \\
\hline $\mathbf{u}$ & $\begin{array}{l}2 \\
3 \\
\end{array}$ & Omar Halfman & septic tank drainfield & $\begin{array}{r}711 \\
523 \\
\end{array}$ & & $\begin{array}{l}10.3 \\
12.4 \\
\end{array}$ & Rowens-Tobosa \\
\hline
\end{tabular}


Appendix 4. Soil Associations of Runnels County, Texas ${ }^{1}$ (Condensed from Wiedenfeld, Barnhill, and Novosad, 1970)

1. Portales-Potter-Mereta association: Nearly level to undulating, loamy soils, moderately deep to very shallow over caliche.

2. Rowena-Tobosa association: Nearly level to gently sloping, deep, loamy and clayey soils.

3. Spur-Colorado-Miles association: Nearly level to gently sloping, deep, loamy soils mainly on flood plains and old stream terraces, but also on Permian limestone and shale.

4. Olton-Vernon-Rowena association: Nearly level to gently sloping, deep, loamy soils on Permian limestone and shale, and gently sloping to steep, shallow, clayey soils on uplands.

5. Cobb-Winters association: Gently sloping to moderately sloping, moderately deep to deep, loamy soils on uplands and Permian limestone and shale.

6. Tarrant-Rough stony land association: Undulating to steep, very shallow, clayey soils and steep stony areas.

${ }^{I}$ Soil associations located on Plate 1. 
7. Talpa-Kavett association: Undulating to steep, loamy and clayey soils, very shallow and shallow over limestones on uplands. 


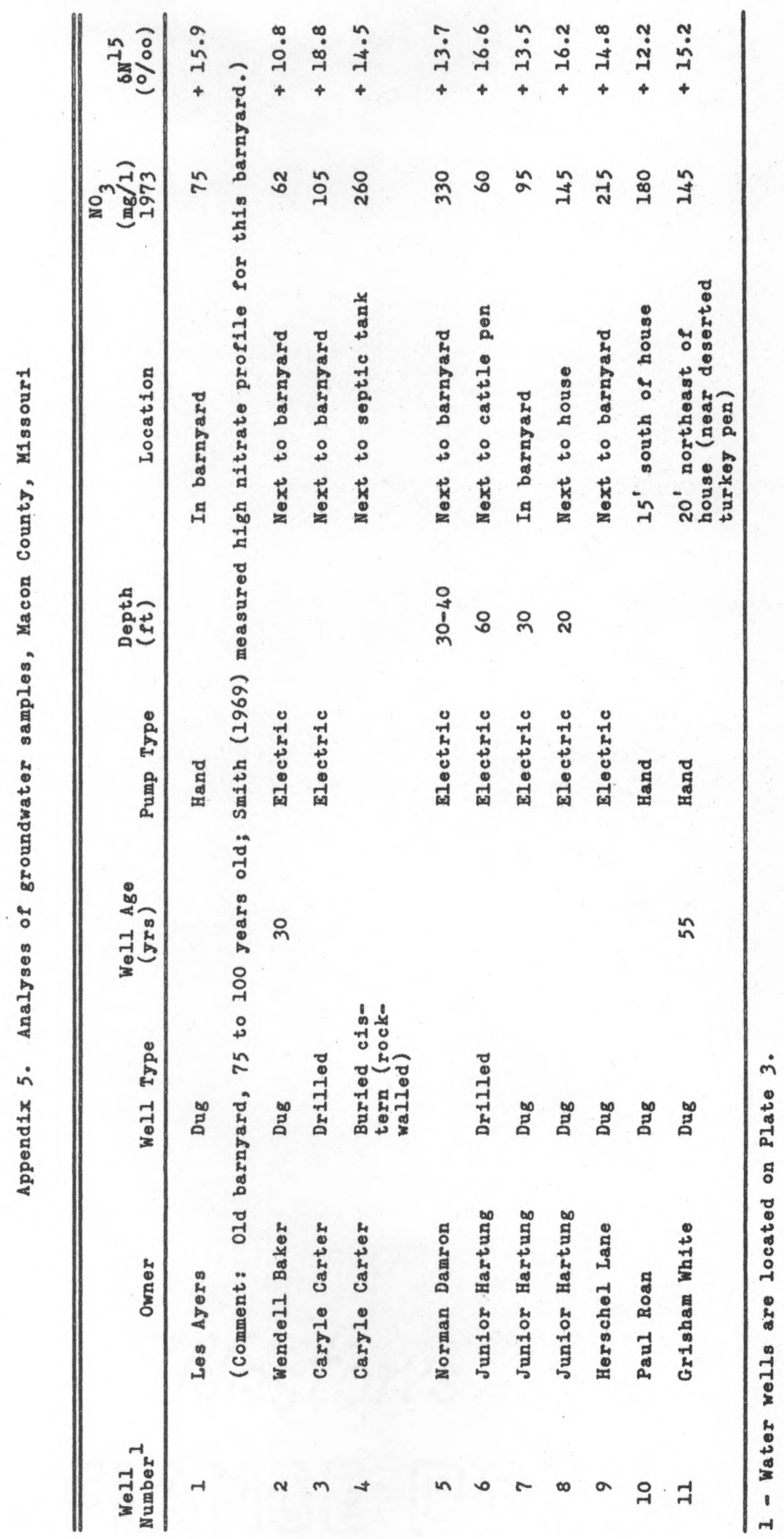


Appendix 6. Groundwater Dates of Waters in Runnels County, Texas, by Tritium Analysis

If agricultural terracing and cultivation were the prime causes of contamination of the groundwaters of southern Runnels County, Texas, then the groundwaters must be as young or younger than the terracing. To confirm this, I had three water samples from the deepest wells in the limestone aquifers analyzed for tritium content by the Teledyne Isotope Corporation (table 22).

Tritium is a radioactive isotope of hydrogen with a half-life of 12.5 years, that is, half of the original tritium will decay to hydrogen in 12.5 years. In 1954 , the New Castle atmospheric nuclear explosions injected large amounts of tritium into the atmosphere. Since then, tritium concentrations in rain water have been much higher than natural tritium levels ( 2 to 10 Tritium Units) (Stewart and Hoffman, 1966). With the use of liquid or gas scintillation counters, tritium concentrations can be determined and post-nuclear bomb waters theoretically can be distinguished from pre-bomb waters. However, the mixing of young and old waters causes interpretation problems. Tritium concentrations slightly above the background levels indicate at least some recent addition of rainwater, whereas high concentrations of tritium confirm the young age of the water. 


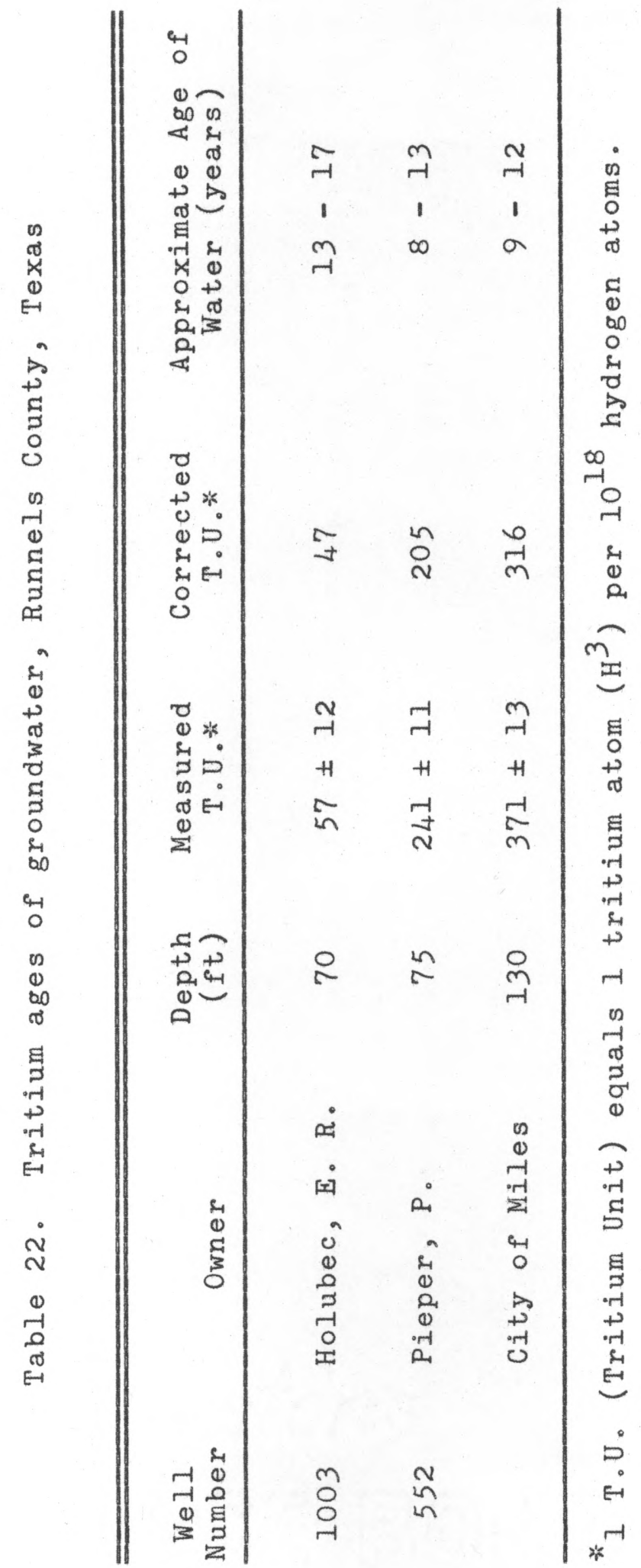


A more precise date may be calculated by estimating the yearly tritium input in rain for a given area, the tritium output at the well, the decay coefficient, the dispersion coefficient, and the tritium fractionation caused by evaporation.

Table 23 lists weighted average annual tritium concentrations based on T, U. contour maps of the United States (Wyerman, T., personal communication, March 1972). Groundwater ages can be calculated from two mathematical models developed by Dincer and Davis (1968). The first model is a simple piston flow equation with a radioactive decay coefficient:

$$
C=C_{0} e^{-\frac{0.693 t}{12.5}}
$$

where:

$$
\begin{aligned}
& \mathrm{C}=\text { output tritium concentration } \\
& \mathrm{Co}=\text { input tritium concentration } \\
& \mathrm{t}=\text { transit time of groundwater }
\end{aligned}
$$

This model assumes no mixing of groundwaters of different years.

The second model, which more likely represents the carbonate aquifer conditions of southern Runnels County, Texas, is a binomial dispersive flow equation with a radioative decay coefficient: 
Table 23. Approximate tritium content of precipitation for $31^{\circ}$ to $33^{\circ} \mathrm{N}$. latitude and $100^{\circ}$ to $105^{\circ}$ W. longitude

\begin{tabular}{|c|c|}
\hline Year & T. $U_{\bullet}^{*}$ \\
\hline 1952 & 8 \\
\hline 1954 & 100 \\
\hline 1955 & 16 \\
\hline 1956 & 45 \\
\hline 1957 & 40 \\
\hline 1958 & 160 \\
\hline 1959 & 170 \\
\hline 1960 & 50 \\
\hline 1961 & 70 \\
\hline 1962 & 470 \\
\hline 1963 & 1300 \\
\hline 1964 & 600 \\
\hline 1965 & 270 \\
\hline 1966 & 180 \\
\hline 1967 & 110 \\
\hline 1968 & 90 \\
\hline
\end{tabular}




$$
f_{0}(t)=\sum_{0}^{+} f_{i}(t-T) e^{-\frac{0.693 t}{12.5}}\left(\frac{n}{x}\right)_{T}(0.50)^{n}
$$

where:

$$
\begin{array}{ll}
f_{0}(t)= & \text { output function } \\
f_{i}(t-T)= & \text { input function } \\
T & =\begin{array}{l}
\text { transit time of ground- } \\
\text { water }
\end{array} \\
\left(\frac{n}{x}\right) \quad & \begin{array}{l}
\text { binomial coefficient which } \\
\text { corresponds to the transit }
\end{array} \\
& \text { time } T \\
n & =\begin{array}{l}
\text { function of binomial dis- } \\
\text { persion }
\end{array}
\end{array}
$$

This model assumes a mixing of groundwaters of a particular year with groundwaters a year younger and a year older.

Before the percolating water reaches the water table, clay mineral adsorption, plant absorption, and evaporation may alter the tritium concentration by isotopic fractionation. Zimmerman et al. (1967) found that plant transpiration had no isotopic effect on $\mathrm{H}^{2}$, thus, no effect on tritium. Stewart (1972) showed that adsorbed meteoric water on clay had a small fractionation.

There is a significant isotopic fractionation of $\mathrm{H}^{2}$ with evaporation, With approximately $50 \%$ evaporation of the original water, there will be an isotopic fractionation of 110\% between hydrogen and deuterium (fig. 25) (Craig et al., 1963). Zimmerman et al. (1967) observed a difference of 


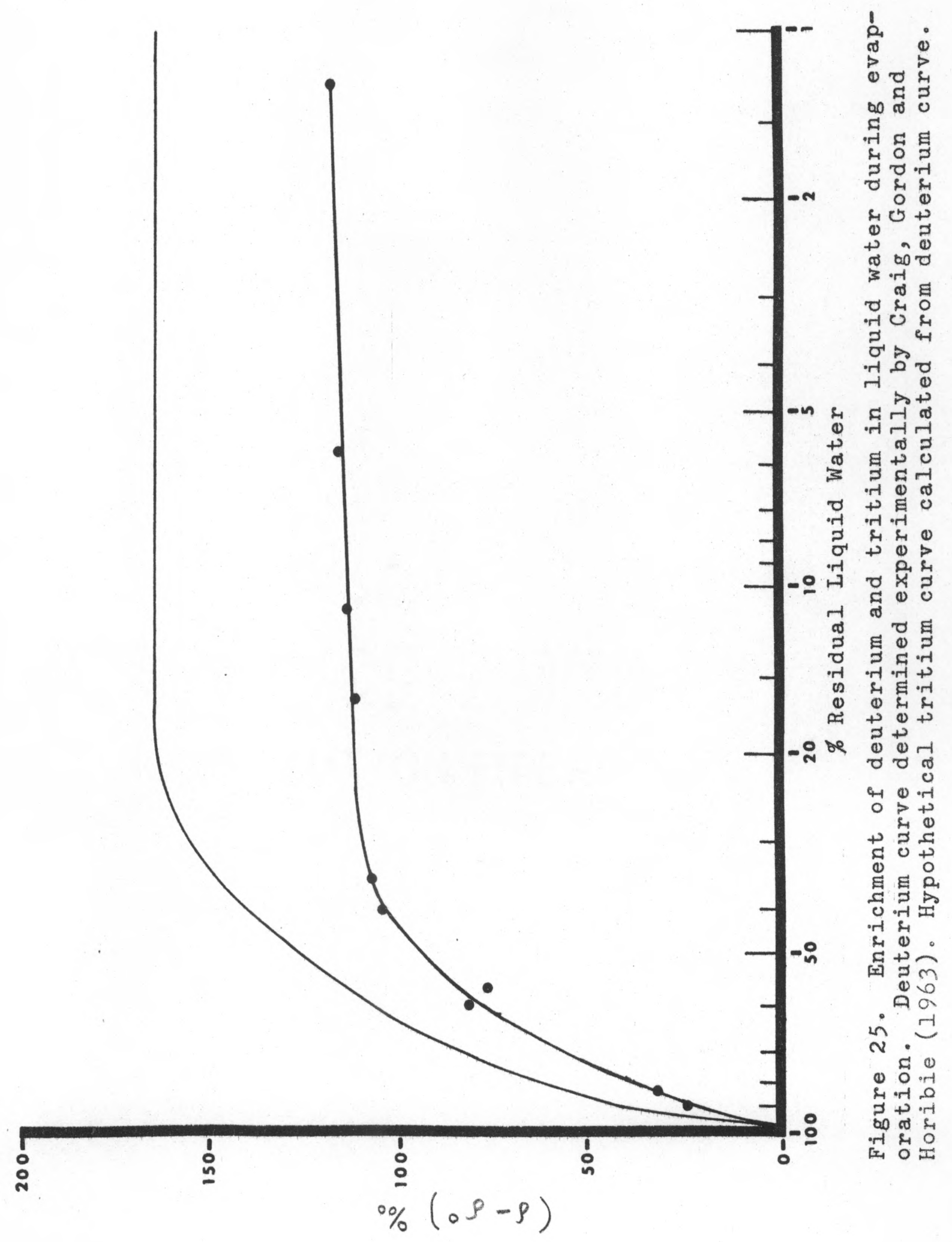


approximately $80 \%$ between rain and water vapor in the same system. Since the isotopic fractionation factor is directly proportional to the mass of the involved molecules, the fractionation of tritium should be $3 / 2$ the fractionation of deuterium. The fractionation of tritium in the residual water in comparison to the original water should be $165 \%$. This means that the measured tritium concentrations may be $165 \%$ more enriched in tritium than the original precipitation. Table 22 ( $p .134$ ) shows the corrected tritium values based on the assumption that there has been $50 \%$ evaporation. The tritium input curve, the tritium plug flow output curve, the tritium dispersive flow output curve, and the corrected tritium concentrations of the three samples are plotted on a semilogarithmic graph (fig. 26). The intersection of the tritium concentrations of the samples with either the dispersive flow output curve or the plug flow curve indicates the approximate age of the groundwater. The approximate ages of groundwaters from wells 1003, 552, and City of Miles are 13 to 17 years old, 8 to 13 years old, and 9 to 12 years old respectively (table 22, p. 134), These waters are younger than the mid-1950's, thus they are younger than terracing. 


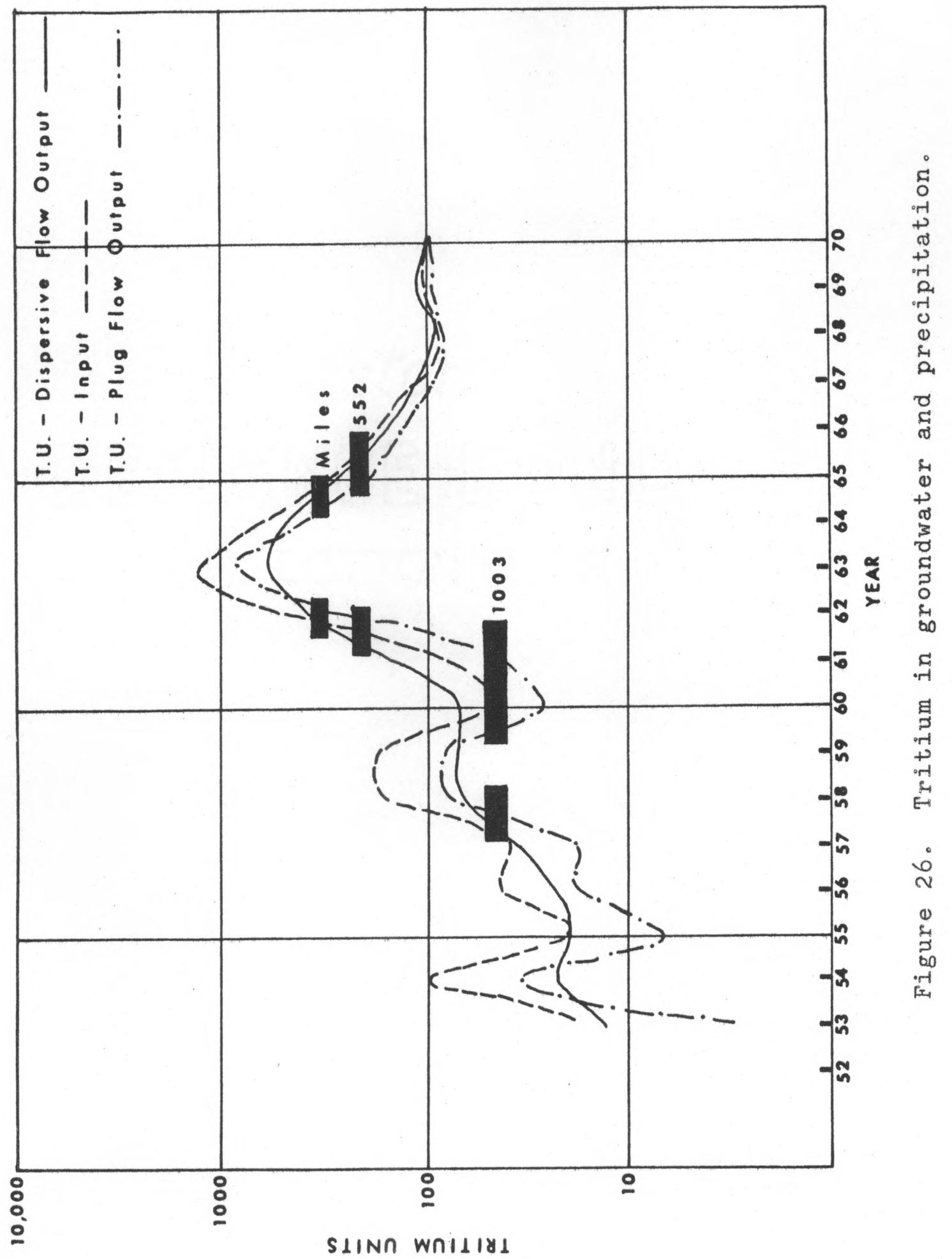




\section{REFERENCES}

Alam, B. S., Saporoschetz, I. B., and Epstein, S. S., 197la, Formation of N-nitrosopiperidine from piperidine and sodium nitrite in the stomach and the isolated intestinal loop of the rat: Nature, v. 232, p. 116-118.

1971b, Synthesis of nitrosopiperidine from nitrate and piperidine in the gastro-intestinal tract of the rat: Nature, v. 232, p. 199-200.

Asahina, S., Friedman, M., Arnold, A., Miller, G., Meisken, M., Bishop, Y., and Epstein, S., 1971, Acute synergistic toxicity and hepatic necrosis following oral administration of sodium nitrate and secondary amines to mice:

Cancer Research, v. 31, p. 1201-1205.

Ayanaba, A., Verstraete, W., and Alexander, M., 1973, Formation of dimethylnitrosamine, a carcinogen and mutagen, in soils treated with nitrogen compounds: Soil Sci. Soc. America Proc., v. 37, p. 565-568.

Balestrieri, Cof 1968, An improved procedure for the measurement of $\mathrm{N}^{15}$ content by mass spectrometry: Life Sciences, v. 7, p. 269-274.

Bartholomew, W. V., and Clark, F。E., 1950, Nitrogen transformations in soil in relation to the rhizosphere microflora: Trans. $4^{\text {th }}$ Internat. Cong. Soil Sci., Amsterdam, v. 2, p. 112-113.

Bigeleisen, J., 1965, Chemistry of isotopes: Science, v. 147, p. 463-471.

Birch, H. F., 1959a, Further observations on humus decomposition and nitrification: Plant and Soil, v.9, no. 3, p. 262-292.

1959b, The effect of soil drying on humus decomposition and nitrogen availability: Plant and Soil, v. 10, no. I, p. 9-31.

Boughey, A. S., Munro, P. E., Meiklejohn, J., Strang, R. M., Swift, J.M., 1964, Antibiotic reactions between African savanna species: Nature, v。203, p. 1302 .

Bremner, J.M., 1965, Isotope-ratio analysis of nitrogen in nitrogen-15 tracer investigations; in Methods of soil 
analysis, part 2 , chemical and microbiological properties: Madison, Wisc., Soc. Agronomy, p. 1256-1285.

Bremner, J.M., and Edwards, A. P., 1965, Determination and isotope-ratio analysis of different forms of nitrogen in soils: 1. Apparatus and procedure for distillation and determination of ammonium: Soil Sci. Soc. America Proc., v. 29, p. 504-507.

Bremner, J. M., and Keeney, D. R., 1966, Determination and isotope-ratio analysis of different forms of nitrogen in soils: 3. Exchangeable ammonium, nitrate, and nitrite by extraction-distillation methods: Soil Sci. Soc. America Proc., v. 30, p. 577-582.

Bremner, J.M., and Tabatabai, M. A., 1973, Nitrogen-15 enrichment of soils and soil derived nitrate: Jour. Environ. Quality, v. 2, p. 363-365.

Bremner, J.M., Cheng, H. H., and Edwards, A. P., 1966, Assumptions and errors in nitrogen-15 tracer research; in Report of the FAO/IAEA Technical Meeting (Braunschweig, Germany, 1963): New York, Pergamon Press, p. 429-442.

Capindale, J., and Tomlin, D., 1957, Mass-spectrometric analysis of elemental nitrogen: Nature, v. 180, p. 701-702.

Carter, J.W., and Allison, F. E., 1960, Investigations on denitrification in well aerated soils: Soil science, v. 90 , p. 173-177.

Challis, B. C., 1973, Rapid nitrosation of phenols and its implications for health hazards from dietary nitrites: Nature, v. 244, p. 466.

Chase, F., Corke, C., and Robinson, J., 1967, Nitrifying bacteria in soils; in Gray, T., and Parkinson, D. (eds.), The ecology of soil bacteria: Liverpool, University Press, p. 593-611.

Cheng, H. H., Bremner, J. M., and Edwards, A. P., 1964, Variations of nitrogen-15 abundance in soils: Science, $v$. $146, \mathrm{p} .1574-1575$.

Chin, W., and Kroontze, W., 1963, Urea hydrolysis and subsequent loss of ammonia: Soil Sci. Soc. America Proc., v. $2, \mathrm{p} .316-318$.

Commoner, B., 1970a, Nitrogen cycle project - progress report 
1969-1970: Center for Biology of Natural Systems, Washington University, St. Louis, Mo,, 37 p.

$1970 \mathrm{~b}$, Threats to the integrity of the nitrogen cycle: nitrogen compounds in soil, water, atmosphere, and precipitation; in Singer, S. R. (ed.), Global effects of environmental pollution: New York, Springer-Verlag., p. 70-95.

Cooke, G., 1967, The control of soil fertility: London, Crosby, Lockwood and Sons, Ltd., $526 \mathrm{p}$.

Craig, H., Gordon, L., and Horibie, Y., 1963, Isotopic exchange effects in the evaporation of water: Jour. Geophys. Research, v. 68, p. 5079-5087.

Delwiche, C. C., and Steyn, P. L., 1970, Nitrogen isotope fractionation in soils and microbial reactions: Environmental Science and Technology, v. 4, no. 11, p. 929-935.

Dincer, T., and Davis, G. H., 1968, Some considerations on tritium dating and the estimates of tritium input function: Internat. Assoc. Hydrogeologists Mémoires, v. 8, (t. 8), Congress of Istanbul, 1967, p. 276-280.

Doak, B. W., 1952, Some chemical changes in the nitrogenous constituents of urine when voided on pasture: partition of nitrogen in herbiverous urine: Jour. Agricultural Sci., v. 42, p. 162-171.

Edwards, A. P., 1973, Isotopic tracer techniques for identification of sources of nitrate pollution: Jour. Environ. Quality, v. 2 , no. 3, p. 382-387.

Ernst, J. W., and Massey, H. F., 1960, The effects of several factors on volatilization of ammonia formed from urea in the soil: Soil Sci. Soc. America Proc., v. 24, p. 87-90.

Feigen, A., and Shearer, G., 1973, The natural abundances of nitrogen-15 in inorganic nitrogen mineralized from soil under field and laboratory conditions: NSF-RANN Trace Contaminants Abstracts, v. 1, no. 2, p. 15.

Feth, S.H., 1966, Nitrogen compounds in natural water - a review: Water Resources Research, v. 2, no. 1, p. 4l-58.

Gaebler, O.H., Choitz, H. C., Vitti, T. G., and Vukmirovich, R., 1963, Significance of $\mathrm{N}^{15}$ excess in nitrogenous compounds of biological origin: Canadian Jour. Biochem. 
Phys., v. 4l, no. 5, p. 1089-1097.

Gaebler, O. H., Vitti, T. G., and Vukmirovich, R., 1966, Isotope effects in metabolism of $14 \mathrm{~N}$ and $15 \mathrm{~N}$ from unlabeled dietary proteins: Canadian Jour. Biochemistry, v. 44 , p. 1249-1257.

Gentile, R., 1967, Mineral commodities of Macon and Randolph Counties: Missouri Geological Survey, Rept. Inv. No. 40 , $106 \mathrm{p}$.

Gillham, R. W., and Webber, L. R., 1969, Nitrogen contamination of groundwater by barnyard leachates: Water Pollution Control Fed. Jour., v. 41, no. 10, p. $1752,1762$.

Gooding, T. H., and McCalla, T. M., 1945, Loss of carbon dioxide and ammonia from crop residues during decomposition: Soil Sci. Soc. America Proc., v. 10, p. 185-190.

Gruener, N., and Shuval, H., 1970, Health aspects of nitrate in drinking water; in Shuval, H. (ed.), Developments in water quality research: Ann Arbor, Ann Arbor Humphrey Science Publisher, p. 77-92.

Haas, H., Evans, C., and Miles, E., 1957, Nitrogen and carbon changes in Great Plains soils as influenced by cropping and soil treatment: U. S. Dept. Agriculture Tech. Bull. $1164,111 \mathrm{p}$.

Harington, J.S., Nunn, J. R., and Irwig, L., 1973, Dimethylnitrosamine in the human vaginal vault: Nature, v. 241 , p. 49-50.

Harr, C. A., 1971, Partial chemical analyses of water from selected sources in Nassau and Suffolk Counties, Long Island, New York: U. S. Geol. Survey (Mineola, New York) Open-file Rept., $21 \mathrm{p}$.

Hauck, R. D., 1973, Nitrogen tracers in nitrogen cycle studies - past use and future needs: Jour. Environ. Quality, v. 2 , no. $3, \mathrm{p} .317-327$.

Hauck, R. D., Bartholomew, W. V., Bremner, J. M., Broadbent, F. E., Cheng, H. H., Edwards, A. P., Keeney, D. R. Legg, J. O., Olsen, S. R., and Porter, L.K., 1972, Use of variations in natural nitrogen isotope abundance for environmental studies: a questionable approach: Science, v. 177, p. 453-454. 
Hoering, T. C., 1955, Variations of nitrogen-15 abundance in naturally occurring substances: Science, v. 122, p. $1233-1234$.

Hoering, T. C., and Ford, H. T., 1960, The isotope effect in the fixation of nitrogen by azotobacter: Am. Chemical Society Jour., v. 82, p. 376-378.

Hooker, M. L., Peterson, G. A., and Sandu, D. H., 1973, Ammonia nitrogen losses from simulated plowing of native sods: Soil Sci. Soc. America Proc., v. 37, no. 2, p. 247-249.

Ingerson, F. E., 1953, Nonradiogenic isotopes in geology: a review: Geol. Soc. America Bull,, v. 64, p. 301-373.

Ishimori, T., 1960, The nitrogen isotopic equilibrium between ammonia and ammonium ion: Chem. Soc. Japan Bull., v. 33, no. 4, p. 516-519.

Jansson, S. I., 1968, Experimental techniques with nitrogen15; in The use of isotopes in soil organic matter studies (FAO/IAEA Technical Meeting, Braunschweig, Germany, 1963): New York, Pergamon Press, p. 415-422.

Jaworski, N., Lear, D., and Villa, 0,, 1971, Nutrient management in the Potomac Estuary: Fed. Water Quality Adm., Maryland Chesapeake Support Lab. Tech. Rept. No. 45, $66 \mathrm{p}$.

Junge, C. E., 1958, The distribution of ammonia and nitrate in rain water over the United States: Amer. Geophys. Union Trans., v. 39, no. 2, p. 24l-248.

Junk, G., and Svec, H. J., 1958, The absolute abundance of the nitrogen isotopes in the atmosphere and compressed gas from various sources: Geochim. et Cosmochim. Acta, v. 14, p. $234-243$.

Keeney, D. R., and Bremner, J. M., 1966, Determination and isotope-ratio analysis of different forms of nitrogen in soils: 4. Exchangeable ammonium, nitrate, and nitrite by direct distillation methods: Soil Sci. Soc. America Proc., v. 30, p. 583-587.

Kimmel, G. E., 1972, Nitrogen content of groundwater in Kings County, Long Island, New York: U. S. Geol. Survey Prof, Paper 800-D, p. D199-D203. 
King, L. D., 1973, Mineralization and gaseous loss of nitrogen in soil-applied liquid sewage sludge: Jour. Environ. Quality, v. 2, no. 3, p. 356-358.

Kirshenbaum, I., Smith, J. S., Crowell, T., Graff, J., and McKee, R., 1947, Separation of the nitrogen isotopes by the exchange reaction between ammonia and solutions of ammonium nitrate: Jour. Chemical Physics, v. 15, no.7, p. $440-446$.

Kohl, D. H., Shearer, G. B., and Commoner, B., 1971, Fertilizer nitrogen: contribution to nitrate in surface water in a corn belt watershed: Science, v. 174, p. 1331-1334.

Kononova, M. M., 1961, Soil organic matter (Nowakowski and Greenwood, trans.): New York, Pergamon Press, 450 p.

Kreitler, C. W., 1972, Nitrate contamination of groundwater in southern Runnels County, Texas: M.A. thesis, Univ. Texas at Austin, $156 \mathrm{p}$.

Lijinsky, W., and Epstein, S. S., 1970, Nitrosamines as environmental carcinogens: Nature, v. 225, p. 21-23.

Martin, D. M., and Goff, D. R., 1972, The role of nitrogen in the aquatic environment: Philadelphia, Contr. Dept. Limnology, Philadelphis Acad. Natural Sciences, ANSP-CLDP-2, $46 \mathrm{p}$.

McCormick, A., Nicholson, M., Baylis, M., and Underwood, J., 1973, Nitrosamines in cigarette smoke condensate: Nature, v. 244, p. 237-238.

Millar, C. E, Turk, L. M., and Foth, H. D., 1958, Fundamentals of soil science: London, John Wiley and Sons, 526 $\mathrm{p}$.

Moore, A., and Russel, J., 1970, Changes in chemical fractions of nitrogen during incubation of soils with histories of large organic matter increase under pasture: Australian Jour. Soil Research, v. 8, p. 2l-80.

Mosier, A. R., Andre, C. E., and Viets, F. G., 1973, Identification of aliphatic amines volatilized from cattle feedyard: Environmental Science and Technology, v. 7, no.7, p. 642-644.

Myaka, Y., and Wada, E., 1967, The abundance ratio of $15 \mathrm{~N} / 14 \mathrm{~N}$ in marine environments: Records of Oceanographic Works 
in Japan, v. 9, no. 1, p. 37-53.

1971, The isotope effect on the nitrogen in biochemical, oxidation-reduction reactions: Records of Oceanographic Works in Japan, v. Il, no. $1, \mathrm{p} .1-6$.

Nassau-Suffolk Research Task Group, 1969, The Long Island water pollution study: New York State Dept. Health, $395 \mathrm{p}$.

Nier, A. D., 1955, Determination of isotopic masses and abundances by mass spectrometry: Science, v. 121, p. 737744 .

Nuhou Kumu Wai (Hawaiian Water Resource News), 1972, Ist results indicate nitrogen build-up, v. 2, no. 4, p. 1.

Perlmutter, N. M., and Koch, E., 1972, Preliminary hydrogeologic appraisal of nitrate in ground water and streams, southern Nassau County, Long Island, New York: U. S. Geol. Survey Prof. Paper 800-B, p. B225-B235.

Riga, A., Van Praag, H. J., and Brigode, N., 1971, Rapport isotopique naturel de $I^{\prime}$ azote dans quelques sols forestiers et agricoles de Belgique soumis a divers traitements culturaux: Geoderma, v. 6, p. 213-222.

Riley, R. F., Richter, E., Rotheram, M., Todd, N., Myers, L. S., Jr., and Nusbaum, R., 1954, The hypobromite and hypochlorite oxidation of ammonium hydroxide, hydrazine, and hydroxylamine: Am. Chemical Soc. Jour., v. 76, p. 33013303 .

Rittenberg, D., 1946, The preparation of gas samples for mass spectrometric analysis; in Wilson, D. W., Nier, A., and Reiman, S. (eds.), Preparation and measurement of isotopic tracers: Ann Arbor, Michigan, J. W. Edwards Co., $108 \mathrm{p}$.

Robinson, J., 1963, Nitrification in a New Zealand grassland soil: Plant Soil, v. 19, p. 173-183.

Schreiner, 0., and Brown, B. E., 1938, Soil nitrogen: U. S. Dept. Agriculture Yearbook 1938, p. 361-376.

Smith, G. E., 1969, Nitrate pollution of water supplies; in Hemphill, D. D. (ed.), Trace substances in environmental health, III: Univ. Missouri $3^{\text {rd }}$ Annual Conf. on Trace Substances in Environmental Health Proc., Columbia, 
Missouri, p. 274-287.

Smith, H., and Vandecaveye, S., 1946, Productivity and organic matter levels of Palouse silt loam as affected by organic residues and nitrogen fertilizers: Soil Sci,, v. 62, p. 283-291.

Soulides, D. A., and Allison, F. E., 1961, Effects of drying and freezing soils on carbon dioxide production, available mineral nutrients, aggregation, and bacterial population: Soil Sci., v. 9l, no. 5, p. 29l-298.

Spedding, C.R. W., 1971, Grassland ecology: Oxford, Clarendon Press, $221 \mathrm{p}$.

Stanford, G., England, C. B., and Taylor, A. W., 1970, Fertilizer use and water quality: U. S. Dept. Agriculture Res. Service, ARS 4l-168, $16 \mathrm{p}$.

Stewart, B. A., 1970, A look at agricultural practices in relation to nitrate accumulation: nutrient mobility in soils accumulation and losses: Soil Sci. Soc. America Spec. Pub. No. 4, p. 47-60.

Stewart, G. I., 1972, Clay-water interaction, the behavior of $3 \mathrm{H}$ and $2 \mathrm{H}$ in adsorbed water, and the isotope effect: Soil Sci. Soc. America Proc., v. 36, p. 421-425.

Stewart, G. L., and Hoffman, C. M., 1966, Tritium rainout over the United States in 1962 and 1963: U. S. Geol. Survey Circ. 520, 11 p.

Stiven, G., 1952, Production of antibiotic substances by roots of a grass (Trachypogon phimosus (H.B.K.) Nees.) and of Pentanisin variabilis: Nature, v. 170, p. 712 .

Stout, P. R., and Burau, R. G., 1967, The extent and the significance of fertilizer build-ups in soils as revealed by vertical distribution of nitrogenous matter between soils and underlying water reservoirs; in Brady, M. (ed.), Agriculture and the quality of our environment: Am. Assoc. Adv. Science, Pub. 85, p. 283-310.

Sylvester, R., 1959, Nutrient content of drainage water from forested, urban, and agricultural areas: U. S. Public Health Service Doc. 16524, 25 p.

Texas Almanac, 1973, 1970 census data: Dallas, Dallas Morning News, $704 \mathrm{p}$. 
Texas Water Development Board, Texas Water Oriented Data Bank, Ground Water Quality System, Program WD500,

Theron, J., 1951, Influence of plants on the mineralization of nitrogen and the maintenance of organic matter in the soil: Jour. Agric. Sci. Camb., v. 41, p. 289-296.

Thompson, L., Black, C., and Zoellinger, J., 1954, Occurrence and mineralization of organic phosphorus in soils with particular reference to associations with nitrogen, carbon, and pH: Soil Sci., v. 77, p. 195-196.

Urey, H. C., 1947, The thermodynamics properties of isotopic substances: Chem. Soc. Jour., p. 562-581.

Urey, H. C., and Greiff, L. J., 1935, Isotopic exchange equilibria: Amer. Chem. Soc. Jour., v. 57, p. 321-327.

Vazhenin, I., and Vazhenina, E., 1969, Transbarkalia: Agrochemistry of Soils of U.S.S.R., v, 7, p. 3-218.

Verstraete, W., and Alexander, M., 1971, Microbial involvement in the formation of dimethylnitrosamine in nature: Jour. Appl. Bacteriology, v. 34, p. IV.

Viets, F. G., Jr., and Hageman, R. H., 1971, Factors affecting the accumulation of nitrate in soil, water, and plants: U. S. Dept. Agriculture, Agr. Research Service, $63 \mathrm{p}$.

Villenski, D. G., 1957, Soil science, (Burron, A., trans.): Jerusalem, Israel Prog. Sci. Translation, $488 \mathrm{p}$.

Volk, G. M., 1959, Volatile loss of ammonia following surface application of urea to turf or bare soils: Agron. Jour., v. $51, \mathrm{p} .746-749$.

Walker, W. G., Bouma, J., Keeney, D. R., and Magdoff, F. R., 1973, Nitrogen transformations during subsurface disposal of septic tank effluent in sands: I. Soil transformations: Jour. Environ. Quality, v. 2, no. 4, p. 475-480.

Walker, W. G., Bouma, J., Keeney, D. R., and Olcott, P. G., 1973, Nitrogen transformations during subsurface disposal of septic tank effluent in sands: II. Ground water quality: Jour. Environ. Quality, v. 2, no. 4, p. 52l525 .

Watkins, S. H., Strand, R. F., DeBell, D. S., and Esch, J., 
1972, Factors influencing ammonia losses from urea applied to northwestern forest soils: Soil Sci. Soc. America Proc., v. 36, no. 2, p. 354-357.

Wellman, R. P., Cook, F. D., and Krouse, H. R., 1968, Nitrogen-15: microbiological alteration of abundance: Science, v. 161, p. 269-270.

Wiedenfeld, C., Barnhill, L., and Novosad, C., 1970, Soil survey of Runnels County, Texas: Washington, D. C., U. S. Department of Agriculture, $60 \mathrm{p}$.

Winton, E. F., Tardiff, R. G., and McCabe, L. J., 1971, Nitrate in drinking water: Am. Water Works Assoc. Jour., v. 63, no. 2, p. 95-98.

Wolff, I. A., and Wasserman, A. E., 1972, Nitrates, nitrites, and nitrosamines: Science, v. 177, no. 4043, p. 15-19.

Zimmerman, V., Ehhalt, D., and Munnich, V., 1967, Soil-water movement and evapotranspiration changes in the isotopic composition of the water; in Isotopes in hydrology: Vienna, Internat. Atomic Energy Agency, p. 567-586. 
The vita has been removed from the digitized version of this document. 
PLATE

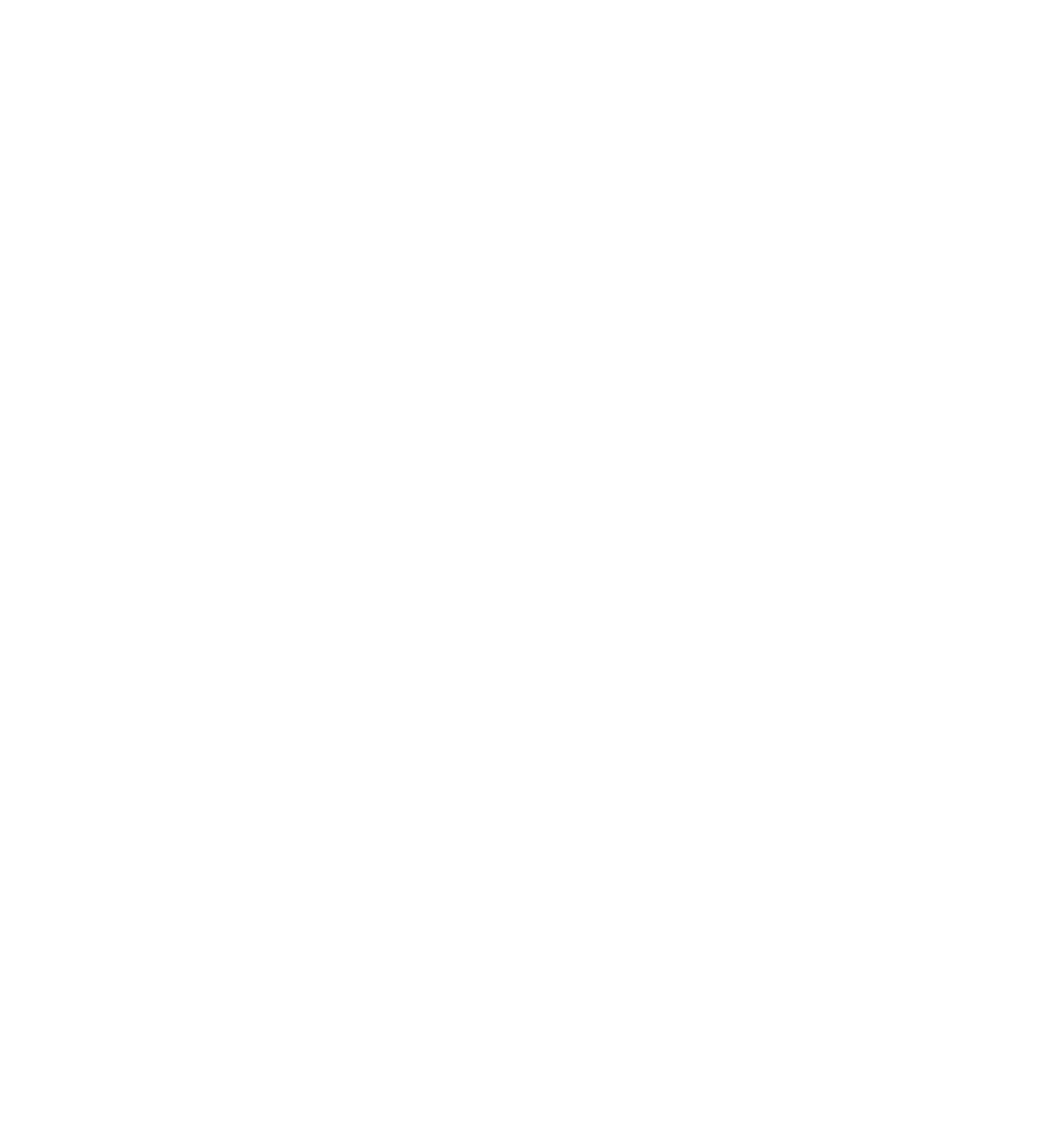

GENERAL SOIL ASSOCIATION AND SOIL SAMPLE LOCATION MA P

RUNNELS COUNTY, TEXAS

$$
\begin{aligned}
& \begin{array}{c}
\text { SCALE } \\
1: 250,000
\end{array}
\end{aligned}
$$

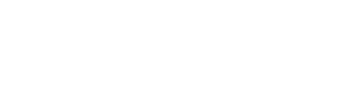

$$
\begin{aligned}
& \text { 닌드 KM }
\end{aligned}
$$

EXPLANATION

SOIL ENVIRONMENTS

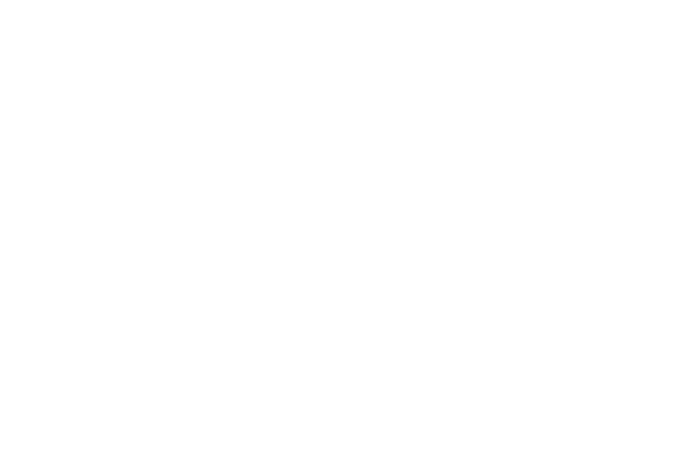

SOIL ASSOCIATIONS

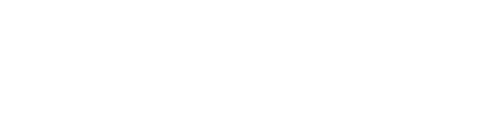

The University of Texas at Austin
Department of Geological Sciences

Soil Associations from Wiedenfeld et al. (1970) 


\section{LOCATION MAP FOR WATER SAMPLES \\ AND SOIL SAMPLES \\ FROM SOUTHERN RUNNELS COUNTY, \\ TEXAS}

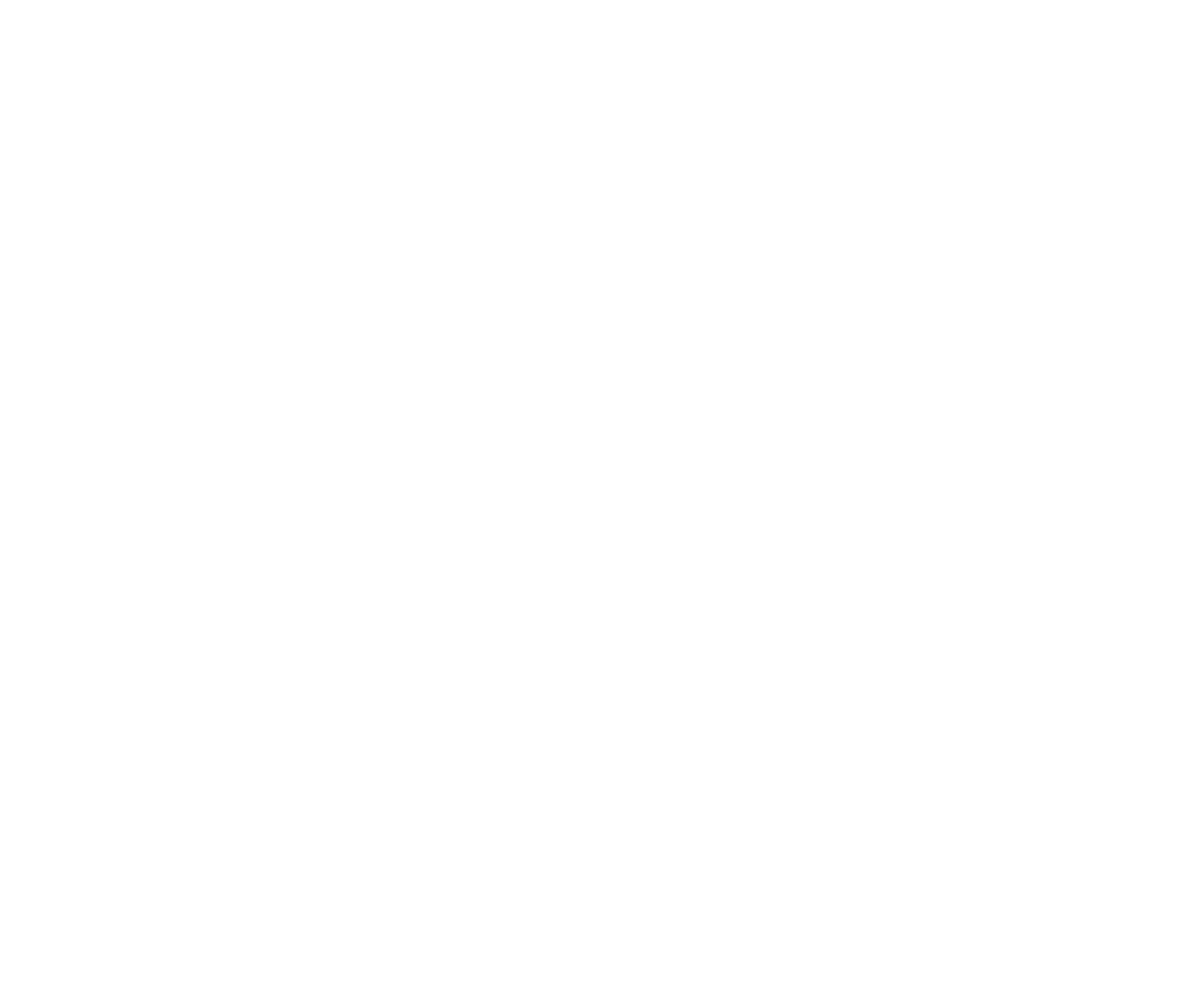


LOCATION MAP FOR WATER SAMPLES

F ROM

PLATE 3

MACON COUNTY, MISSOURI

SCALE
$1: 125,000$

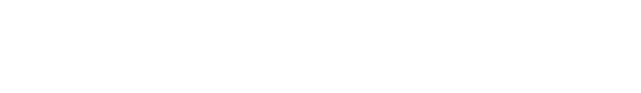

0

EXPLANATION

- Sompling location and number
(Detailed information in Appendix s)

(36) - U.S. Highway

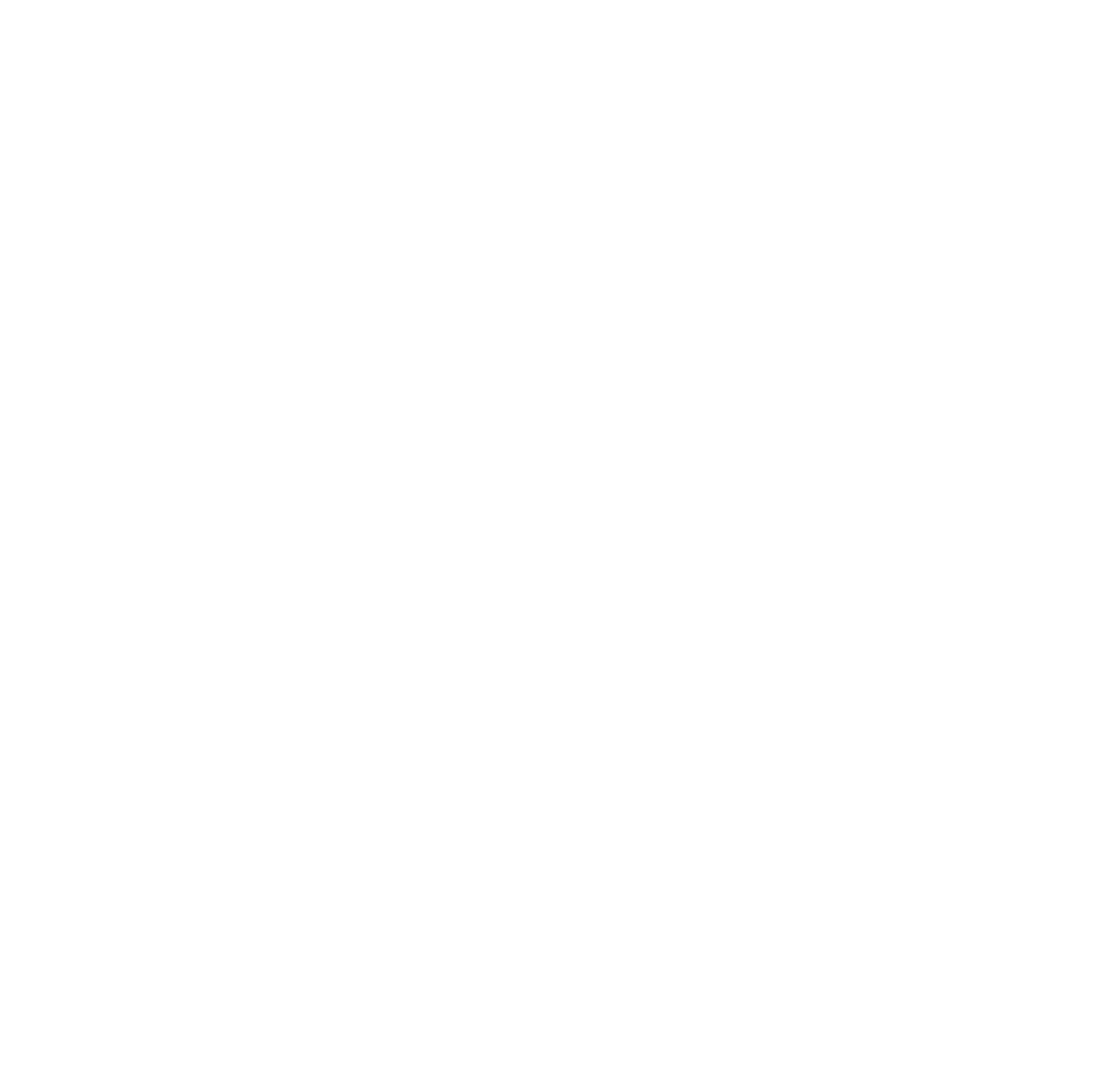




\section{LOCATION MAP FOR WATER SAMPLES}

\section{FROM QUEENS AND NASSAU COUNTIES,}

\section{NEW YORK}

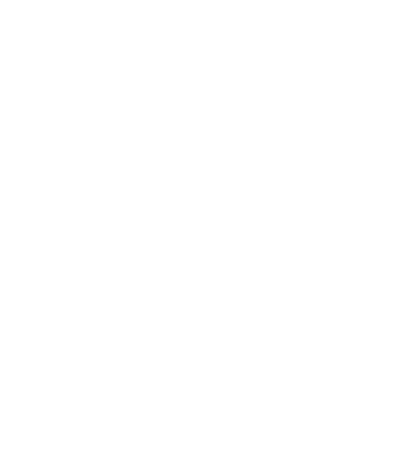
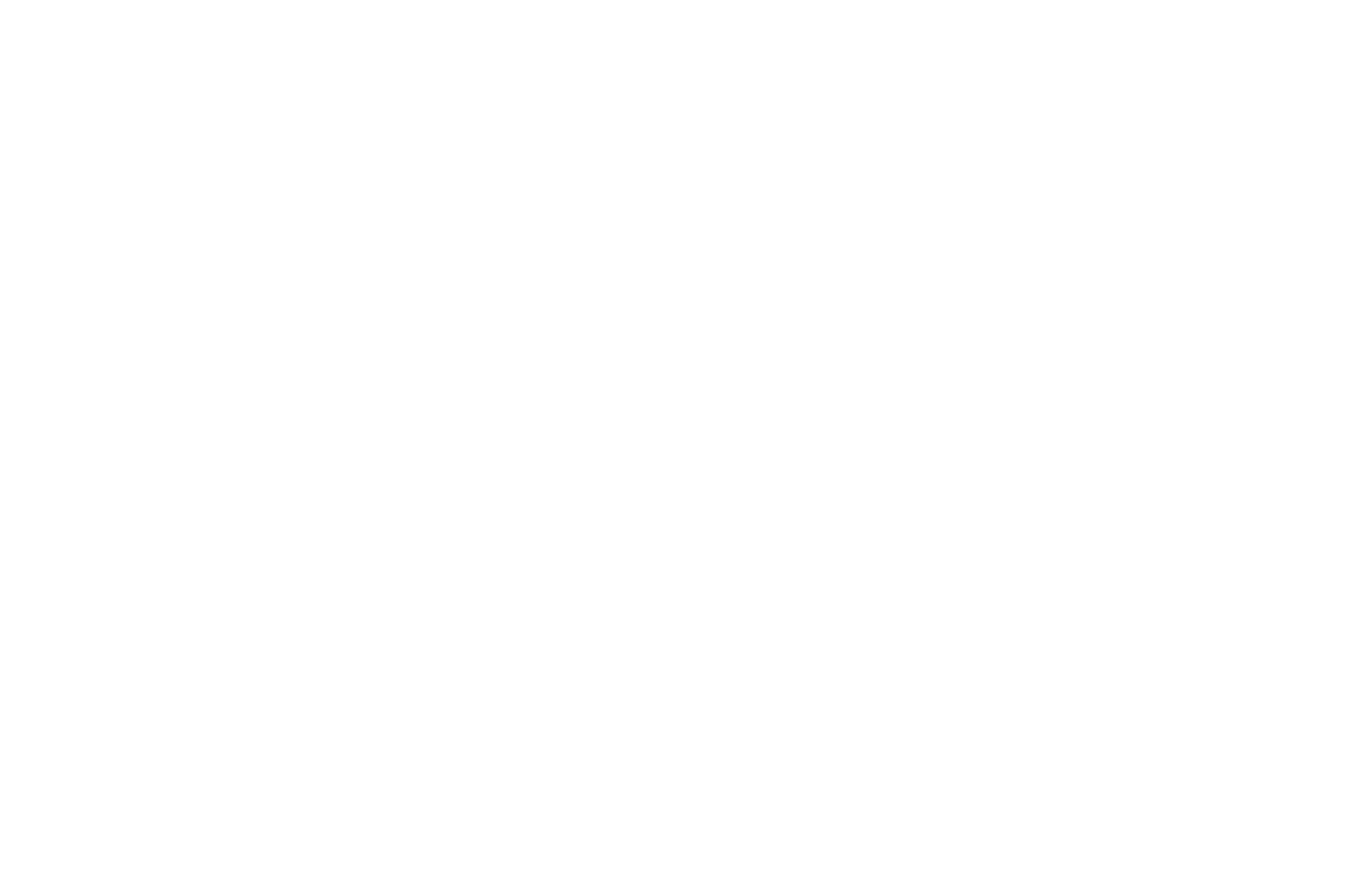

Charles W. Kreitler

The University of Texas at Austin Department of Geological Sciences Spring, 1974 